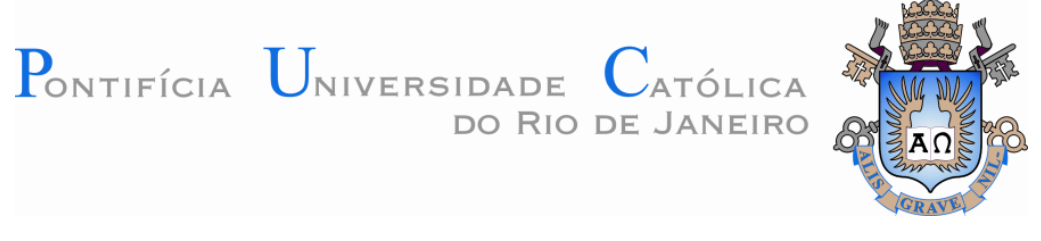

Catherina Bresciane Godeghesi

'The Right Inputs in Afghanistan':

A Paz Liberal no Afeganistão como Segurança para o Ocidente

Dissertação de Mestrado

Dissertação apresentada como requisito parcial para obtenção do título de Mestre pelo Programa de Pós-graduação em Relações Internacionais do Instituto de Relações Internacionais da PUC-Rio.

Orientador: Prof. Kai Michael Kenkel

Rio de Janeiro Março de 2015 
Catherina Bresciane Godeghesi

\title{
'The Right Inputs in Afghanistan': A Paz Liberal no Afeganistão como Segurança para o Ocidente
}

Dissertação apresentada como requisito parcial para obtenção do título de Mestre pelo Programa de Pós-graduação em Relações Internacionais do Instituto de Relações Internacionais da PUC-Rio. Aprovada pela Comissão Examinadora abaixo assinada.

\begin{abstract}
Prof. Kai Michael Kenkel
Orientador e Presidente Instituto de Relações Internacionais - PUC-Rio
\end{abstract}

Prof. Rafael Duarte Villa Instituto de Relações Internacionais - USP

Profa. Maíra Siman Gomes Instituto de Relações Internacionais - PUC-Rio

Profa. Monica Herz

Vice-Decana de Pós-Graduação do Centro de Ciências Sociais - PUC-

Rio

Rio de Janeiro, 24 de Março de 2015 
Todos os direitos reservados. É proibida a reprodução total ou parcial do trabalho sem a autorização da universidade, da autora e do orientador.

\section{Catherina Bresciane Godeghesi}

Graduou-se em Relações Internacionais na Pontifícia Universidade Católica de São Paulo em 2012.

Ficha Catalográfica

\begin{tabular}{|c|}
\hline Godeghesi, Catherina Bresciane \\
\hline $\begin{array}{l}\text { 'The right inputs in Afghanistan' : a paz } \\
\text { liberal no Afeganistão como segurança para o } \\
\text { ocidente / Catherina Bresciane Godeghesi ; } \\
\text { orientador: Kai Michael Kenkel. }-2015 \text {. } \\
175 \text { f. : il. (color.) ; } 30 \mathrm{~cm}\end{array}$ \\
\hline $\begin{array}{l}\text { Dissertação (mestrado)-Pontifícia } \\
\text { Universidade Católica do Rio de Janeiro, Instituto } \\
\text { de Relações Internacionais, } 2015 \text {. } \\
\text { Inclui bibliografia }\end{array}$ \\
\hline $\begin{array}{l}\text { 1. Relações internacionais - Teses. } 2 . \\
\text { Paz liberal. 3. Liberalismo. 4. Operações de paz. } 5 . \\
\text { Afeganistão. 6. Drogas. 7. Segurança. I. Kenkel, } \\
\text { Kai Michael. II. Pontifícia Universidade Católica do } \\
\text { Rio de Janeiro. Instituto de Relações } \\
\text { Internacionais. III. Título. }\end{array}$ \\
\hline
\end{tabular}

CDD: 327 


\section{Agradecimentos}

Estes dois anos de trabalho só foram possíveis graças ao imenso apoio que tive de muitas pessoas importantes.

Gostaria de agradecer ao corpo de professores da PUC-Rio por sempre motivar e estimular o debate, e pela sólida formação acadêmica e crítica que me proporcionaram.

Ao meu orientador, Kai Michael Kenkel, pelo acolhimento, atenção e disposição que foram absolutamente essenciais para realizar o trabalho. Muito obrigada por todo o tempo dedicado.

Ao IRI por todas as oportunidades de aprendizado, aos funcionários do IRI pelo apoio logístico e pela disposição a todos os momentos.

À banca, meus sinceros agradecimentos pela atenção e disponibilidade.

A minha família, pelo amor e apoio incondicionais ao longo desses dois anos. São meu porto seguro e sou eternamente grata a tudo que me proporcionaram.

Aos meus colegas de turma, que foram essenciais para passar por todas as dificuldades, e pelo entendimento mútuo. Obrigada Luísa, Felippe e Raduan por compartilharem de todos esses momentos.

Ao João, para quem não tenho nem palavras para expressar toda a minha gratidão pelo apoio incondicional durante esses dois anos.

Aos amigos e amigas em São Paulo, que gostaria muito de poder mencionar todos os nomes, pelo carinho e amizade que continuou o mesmo, apesar da distância.

A CAPES - Coordenação de Aperfeiçoamento de Pessoal de Nível Superior e à Pontifícia Universidade Católica do Rio de Janeiro (PUC-Rio), por todo o auxílio, que apenas através deles foi possível realizar este mestrado. 


\section{Resumo}

Godeghesi, Catherina Bresciane; Kenkel, Kai Michael. 'The Right Inputs in Afghanistan': A Paz Liberal no Afeganistão como Segurança para o Ocidente. Rio de Janeiro, 2015. 175 p. Dissertação de Mestrado - Instituto de Relações Internacionais, Pontifícia Universidade Católica do Rio de Janeiro.

A paz liberal é um projeto político cujas tradições remontam ao conjunto de ideias que compõem o liberalismo. Ela representa o modelo pelo qual o ocidente se propõe a uniformizar o mundo através da democracia e de réplicas de instituições, normas e sistemas econômicos, sociais e políticos. Assim, pensar em tal projeto implica pensar também em seus aspectos práticos e na sua implementação. A paz liberal foi escolhida como objeto de estudo da dissertação porque, na medida em que se traduz em uma relação hierárquica baseada em interesses, acarreta em uma série de exclusões e marginalizações, uma vez instaurada através de uma operação de peacebuilding. A presente pesquisa procura entender quais as suas reais motivações, através da busca por qual seu objeto referente de fato: o indivíduo do país receptor ou o estado mandante? Para ilustrar tal reflexão, foi conduzida uma investigação através de um estudo de caso da missão de peacebuilding no Afeganistão, e como a questão da produção vertiginosa do ópio em tal país, que cresceu após a entrada de tais operações, pode indicar uma resposta acerca de qual o objeto referente de fato da paz liberal pós $11 / 9$.

\section{Palavras-chave}

Paz Liberal; Liberalismo; Operações de Paz; Afeganistão; Drogas; Segurança 


\section{Abstract}

Godeghesi, Catherina Bresciane; Kenkel, Kai Michael (Advisor). The Right Inputs in Afghanistan: The Liberal Peace in Afghanistan as Security to the West. Rio de Janeiro, 2015. 175 p. MA. Dissertation Instituto de Relações Internacionais, Pontifícia Universidade Católica do Rio de Janeiro.

The liberal peace is a political project rooted in the set of ideas and values that sustain liberalism as an ideology. It represents a model through which the west gauges the world by bringing in democracy and by replicating institutions, norms and economic, social and political systems. Thinking about such project implies that there are practical and implementation aspects that cannot be ignored. Liberal peace has been chosen as the theme of this dissertation because it is about a hierarchical relationship between North and South that produces exclusions and marginalizations that happen through peacebuilding operations. This research aims to understand what the real motivations behind the liberal peace project are, by seeking which is its real referent object: the individual who lives in the state being intervened or the western countries national securities? In order to illustrate the findings for such questions, this research has carried out a case study focused on NATO's operations in Afghanistan and the concurring vertiginous growth of opium production in the country. This will lead us to understand what the real referent object behind the liberal peace project after $9 / 11$ is.

\section{Keywords}

Liberal Peace; Liberalism; Peace Operations; Afghanistan; Drugs; Security 


\section{Sumário}

Introdução 10

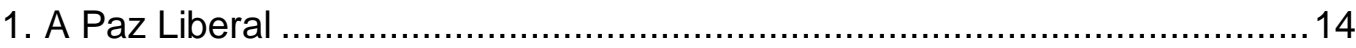

1.1 A Tradição Liberal nas Relações Internacionais ....................................16

1.1.1 O Liberalismo Clássico ................................................................. 17

1.1.2 O Liberalismo e as Relações Internacionais .........................................19

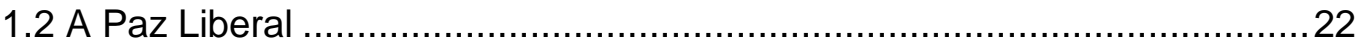

1.3 Definições Críticas para a Paz Liberal ....................................................26

1.4 A Evolução das Operações de Paz ......................................................29

1.5 As Críticas à Paz Liberal.......................................................................... 41

1.5.1 O Norte e Sul Globais e a Nova Ordem Geopolítica ............................ 41

1.5.2 Mark Duffield: Segurança, Subdesenvolvimento e Shadow Economies .. 43

1.5.3 Michael Pugh: Peacebuilding e Bem-estar..........................................45

1.5.4 Oliver Richmond e a Valorização do Indivíduo Local ..............................47

2. As Diferentes Concepções de Segurança...............................................50

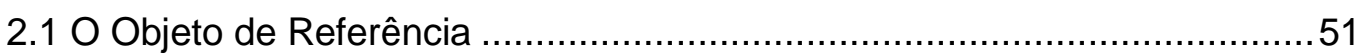

2.2 Concepção Tradicional de Segurança ...................................................53

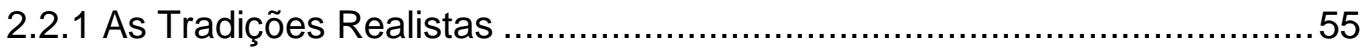

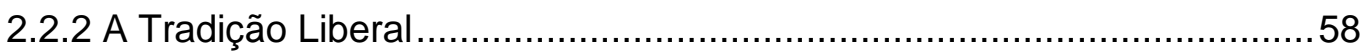

2.3 Segurança e Liberalismo Sob o Ponto de Vista Crítico .............................61

2.4 A Expansão dos Estudos de Segurança ................................................. 67

2.5 A Securitização e a Escola de Copenhague ..........................................70

2.6 Os Estudos Críticos da Segurança e o Aprofundamento ..........................73

2.7 O Nexo Segurança e Desenvolvimento ............................................... 75 
3. As Práticas da Paz Liberal 82

3.1 Segurança Humana como Framework para Operações de Peacebuilding pré- $11 / 9$ 83

3.2 As Diferentes Concepções de Segurança para as Operações de Paz e As Novas Operações de Estabilização

4. Metodologia da Análise de Discurso .92

4.1 Metodologia e Pressupostos Teóricos da Análise de Discurso nas Relações Internacionais .93

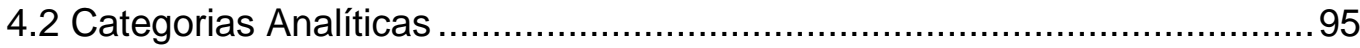

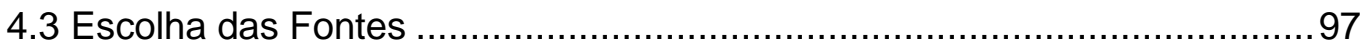

5. Segurança e Ópio no Afeganistão …................................................. 99

5.1 Um Panorama Histórico do Afeganistão ............................................... 101

5.1.1 A Formação do Estado Afegão ....................................................101

5.1.2 Os Mujahedin durante a Ocupação Soviética .....................................108

5.1.3 A Guerra Civil no Afeganistão ..........................................................112

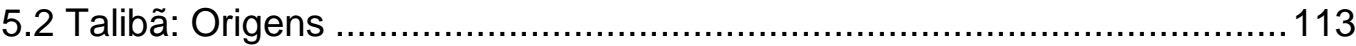

5.3 Um Histórico da Proibição do Ópio ....................................................115

5.4 O Ópio e os Narcóticos como shadow economies ...................................118

5.5 A Guerra Civil no Afeganistão e a Emergência da Produção do Ópio ......121

5.6 Economia do Ópio durante o período Talibã ........................................122

5.7 A Produção do Ópio pós 11/9 ......................................................... 125

5.8 A Intervenção da OTAN e as Políticas de Combate ao Ópio Adotadas.... 128

6. O Conflito no Afeganistão e seu(s) Objeto(s) de Referência ......................135

6.1 O Acordo de Bonn ................................................................................. 141

6.2 A Participação do Reino Unido no Conflito..........................................145

6.3 Os Estados Unidos sob Mandato de George W. Bush........................... 147

6.4 O Conflito Durante o Governo Obama .............................................149 
7. A Paz Liberal como Segurança para o Ocidente e seus Objetos

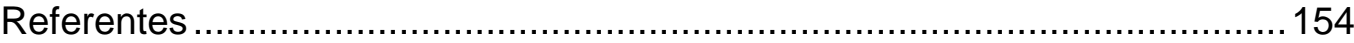

7.1 As Lacunas entre Retórica e Prática ....................................................... 155

7.2 O Impacto dos Atentados de 11/9 no Objeto Referente da Paz Liberal....157

7.3 As Relações entre Liberalismo e a Paz Liberal .....................................162

7.4 Conclusões Sintéticas........................................................................ 165

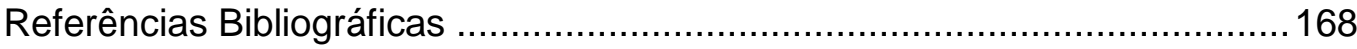




\section{Introdução}

Pensar na paz liberal deve significar pensar também em seus aspectos práticos e implicações quanto a sua implementação, a partir de operações de peacekeeping ou de peacebuilding. Sobretudo nas consequências decorrentes de tais processos, tanto porque determinados interesses se sobrepõem frente a outros, e também porque geram marginalizações e exclusões, indicando uma relação de poder altamente hierárquica.

A paz liberal é um projeto hegemônico, de exportação de um modelo essencialmente ocidental, composto de valores e instituições, em vistas de se uniformizar o mundo e remediar ameaças e subdesenvolvimento, com base na crença da existência de uma "paz separada" entre os estados liberais-democráticos (Doyle, 2012; Richmond, 2011; Duffield, 2001; 2007). Em termos mais precisos, as operações de peacebuilding refletem uma ideologia que pauta as ações de um complexo sistema de governança global responsável por conjugar as relações entre norte e sul globais, que se traduzem em uma relação desigual e hierárquica (Duffield, 2001).

A paz liberal foi escolhida como objeto de estudo do presente trabalho porque, na medida em que se traduz em uma relação hierárquica, ela se baseia em interesses, no caso, do norte global. Isso implica em uma série de exclusões e marginalizações, uma vez instaurada através de uma operação de peacebuilding. Assim, nos interessa aqui entender quais as suas reais motivações, bem como o que acontece de fato na prática. Embora os valores que estejam no cerne da paz liberal remetam as tradições do liberalismo, e, logo, da importância da liberdade do indivíduo, muitas vezes o próprio é marginalizado, quando se trata do país receptor, no caso, do sul em desenvolvimento.

Desse modo, para que a pesquisa não se limite apenas a aspectos teóricas, essa discussão merece ser visualizada através de um caso real. O Afeganistão foi 
selecionado para o presente estudo por apresentar a seguinte particularidade: desde que as operações dos Estados Unidos, e, em seguida, da Organização do Tratado do Atlântico do Norte (OTAN) tiveram início, houve um boom na produção de opiáceos, que tornou o Afeganistão o maior produtor da droga no mundo.

A despeito do caminho que foi percorrido para escolha da temática a ser estudada, ela emerge a partir da indagação de como entender a marginalização da questão das drogas nas operações da OTAN no Afeganistão. É alarmante o quanto a produção dos opiáceos deslanchou desde a entrada dos Estados Unidos, ainda na Operation Enduring Freedom, até o final do mandato da International Security Assistance Force (ISAF). Essa indagação evoluiu para enquadrar esse questionamento em vistas de se entender quais as motivações de fato por trás da paz liberal. Ora, se houve essa exclusão quanto as drogas, talvez os indivíduos no caso, a população afegã - não tenham sido incluídos na operação de maneira prioritária. A população afegã precisou a recorrer a economias ilegais para subsistência, de modo que o novo sistema sendo implementado não estaria provendo o bem-estar tal como prometido pela paz liberal. Ou seja, exclusões e marginalizações foram produzidas na operação de peacebuilding empreendida no Afeganistão.

A questão das drogas é de extrema relevância atualmente. O regime proibitivo está sendo questionado, e observa-se a descriminalização das drogas em diversos lugares do mundo, inclusive os Estados Unidos. No Afeganistão, no entanto, o que ocorreu foi que o Talibã permitia a produção em seu regime. No entanto, assim que a democracia segundo os moldes liberais foi instaurada, como parte de um acordo firmado dentro do complexo sistema de governança global, a produção foi proibida, e, ainda assim, cresceu vertiginosamente.

Para tanto, o que propomos aqui é entender, como no caso de uma operação de peacebuilding, uma questão de tamanha relevância pode ter sido marginalizada, sobretudo se ela já foi reconhecida como uma das bases de financiamento dos movimentos "insurgentes" no próprio Afeganistão, que estariam lutando contra as forças da OTAN naquele território. O estudo será feito a partir de uma análise do framework da paz liberal, e se utilizará de ferramentas metodológicas e de análise específicas que fornecerão o caminho para encontrar as respostas que procuramos. Ou seja, qual (ou quais) são os objetos de referência 
da paz liberal no discurso? E qual (quais) são de fato? Qual a concepção de segurança por trás da paz liberal? E no caso da missão dos EUA e OTAN? E como isso explica a marginalização das drogas no caso do Afeganistão? Tais questionamentos nos permitirão expor as contradições por trás do projeto hegemônico da paz liberal, e suas exclusões e marginalizações.

O trabalho será estruturado da seguinte maneira: o capítulo 1 será responsável por fornecer as bases teóricas a respeito da paz liberal. Assim, em primeiro lugar, discutir-se-á o liberalismo como ideologia e tradição filosófica, qual o lugar do indivíduo ao longo de sua trajetória, o que a ideologia promove, quais seus valores centrais, e, por fim, quais seus principais expoentes e origem. Em segundo lugar, o capítulo tratará do liberalismo como uma escola nas Relações Internacionais, e buscará compreender quais as bases e legados deixados por Kant para tal, qual sua presença na retórica - frequente entre grandes líderes de potências ocidentais, e, por fim, como se consolidou como paradigma. Em terceiro lugar, discutiremos e conceituaremos a própria paz liberal, quais suas relações com o próprio paradigma e tradição liberal, e qual a definição. Para, em seguida, entender como se deu a evolução das operações de paz até chegar no peacebuilding, que entendemos como a sua cristalização. Por fim, o capítulo fornecerá os fundamentos teóricos críticos que servirão para construir a crítica e argumentação final desse trabalho.

O capítulo 2 também estabelecerá outra parte do arcabouço teórico, no entanto, voltada para a subárea da segurança nas Relações Internacionais. Essa parte definirá também a principal unidade analítica a ser utilizada ao longo da pesquisa: o objeto referente, sua definição e origem. Em seguida, a própria subárea será tratada, com base na existência das diferentes concepções de segurança existentes, a saber: tradicional, o liberalismo, e, por fim, os processos de ampliação e aprofundamento da subárea e como a agenda de pesquisa passa a abordar outras temáticas, que não restritas apenas aos estados. A sessão seguinte discute as relações entre liberalismo e segurança, procurando desvelar o que de fato o liberalismo entende por liberdade aos indivíduos. Em seguida, versaremos sobre o nexo entre desenvolvimento e segurança, que se tornou o framework dominante para as operações de peacebuilding a partir da década de 1990. A última etapa desse capítulo se debruça sobre o conceito de segurança humana, e 
de que maneira ele representou, retoricamente, uma mudança de objeto referente na política internacional.

O terceiro capítulo se propõe a tecer a argumentação com relação a prática da paz liberal, ou seja, investiga-se, em primeiro lugar, de que maneira o conceito de segurança humana pode ser entendido como um framework que moldou as operações de peacebuilding que precederam a década de 2000. Em seguida, será discutido que mudanças se decorreram em virtude dos atentados do "11/9" no que se refere as práticas da paz liberal, e de que maneira houve um processo de militarização do humanitarismo. Serão discutidas também as diferentes concepções de segurança existentes por trás das operações de paz.

O quarto capítulo pretende apresentar as bases teóricas para a condução de um estudo através da análise de discurso, que acontecerá no capítulo seis desse trabalho.

Já o quinto capítulo é o responsável pelo estudo de caso sobre o Afeganistão e servirá também para investigar qual o objeto referente de fato por trás das operações de peacebuilding. Assim, sua primeira tarefa é a de se expor um panorama histórico sobre o estado em questão, quais as particularidades de sua trajetória, e uma discussão sobre em que medida tratamos de um estado de fato. Além disso, será apresentada qual a origem da produção do ópio no Afeganistão, um breve resumo acerca da proibição do narcótico, uma análise sobre a economia do ópio no Afeganistão com base nas shadow economies, e uma análise sobre as políticas de erradicação e combate que foram adotadas pela OTAN após o início do conflito.

O sexto capítulo continuará a investigação empírica, utilizando a análise de discurso de textos relevantes para o caso estudado, como, por exemplo discursos de presidentes como George W. Bush e Obama, e textos oficiais do governo britânico. Tal leitura nos permitirá observar quais os objetos referentes, tais como definidos por tais atores - no discurso, enquanto, na prática, já foi visto no capítulo anterior.

Por fim, o sétimo capítulo fornecerá as conclusões com base nas investigações teóricas a práticas a respeito da paz liberal, objeto de estudo central da pesquisa, enquanto as conclusões finais servirão para tecer comentários sintéticos a respeito da pesquisa completa. 


\section{A Paz Liberal}

O final da Guerra Fria significou um marco quanto a grandes mudanças no âmbito da política internacional. $\mathrm{O}$ embate bipolar era caracterizado por ser essencialmente sistêmico, majoritariamente dividindo o mundo entre duas orientações ideológicas opostas. Com o seu fim, novos conflitos e desastres humanitários emergiram durante a década de 1990, mudando o foco da política internacional, que deixaria de ser estado-cêntrica e se tornaria preocupada com o indivíduo. Normas e conceitos emergiram com base nessa nova configuração, objetivando proteger o indivíduo e evitar que novos desastres humanitários, a exemplo dos genocídios em Ruanda e em Srebrenica, nos anos de 1994 e 1995, respectivamente, ocorressem. Ou seja, o indivíduo se tornaria crescentemente o objeto referente em relação a problemas de segurança durante a década de 1990, embora não exclusivamente.

Além disso, esse período também foi importante pelo advento e disseminação da paz liberal como um modelo para reconstruir sociedades afetadas por conflitos. Durante a guerra fria, a ONU passou por um período de congelamento devido a bipolaridade, que impediu com que muitas decisões fossem tomadas. Havia também cautela por parte da organização em relação a promover determinada ideologia, ou que denotasse inclinação para um dos lados em questão. No entanto, isso não impediu com que tomasse parte em determinados projetos ou operações de paz.

Embora as noções de paz liberal e paz democrática precedam a década de 1990, sua exportação para além do Ocidente ocorreram principalmente durante esse período, embora alguns considerem que seja uma continuidade do imperialismo (Richmond, 2012). 
Uma das premissas da paz liberal, sobretudo de uma tradição que se baseia em estudos quantitativos para comprovar a seguinte afirmação, estabelece que democracias liberais não entram em guerra entre si (Singer and Small, 1976; Russett, 1993; Bueno de Mesquita, 1999) -, de modo que, para construir uma ordem global pacífica, seria necessário propagar a democracia e os valores liberais para o resto do mundo, transformando ambientes não democráticos para que exista a paz (Doyle, 2012). Ou, como também coloca Doyle (2012, p. 167), através de três atributos essenciais ao liberalismo: “(...) by establishing domestic liberty, political participation, and market exchange one can have international payoff of peace as well"

Quanto as operações de paz e resoluções de conflitos, o peacebuilding per se é reflexo dessas mudanças e transformações pelas quais o mundo passou com o fim da bipolaridade, ainda que também existissem antes do período referido. $\mathrm{O}$ peacebuilding revela essa busca por um modelo que se baseia na implementação de instituições, de democracia participativa e realização de eleições, economias de mercado, do estado de direito e sob os moldes vestfalianos, calcados nos valores expressos nos discursos liberais, que visam a liberdade do indivíduo e uma sociedade mais justa. Ou ainda, conforme sugerido pelo relatório Agenda for Peace, “(...)action to identify and support structures which will tend to strengthen and solidify peace in order to avoid a relapse into conflict" (Boutros-Ghali, 1992).

O que nos importa no presente trabalho é procurar entender para quem a paz liberal é construída - ou seja, se é para o indivíduo no país receptor, ou se é para o país mandante da missão - no âmbito das operações, principalmente, de peacebuilding. Ou seja, seria a paz liberal construída para o bem-estar do país receptor da missão? Ou seria para atender os interesses dos estados mandantes? Como está colocado o indivíduo nesse contexto?

A despeito das operações de paz, não são mais empreendimentos exclusivos das Nações Unidas, e envolvem uma ampla gama de outros atores. Assim, em termos analíticos, buscar-se-á compreender qual o objeto referente de fato, de tais missões, na prática, embora a ideologia e o discurso possam expressar outro. O objeto referente é, em linhas gerais, "things that are seen to be existentially threatened and that have a legitimate claim to survival (Buzan et al, 1998, p. 36)". É importante ressaltar que essa definição não se restringe apenas ao 
estado. Os autores descrevem coletividades e grupos como também passíveis de serem objetos referentes, que podem ser identificados como algo que está sendo ameaçado. Sobretudo como resultado da ampliação e aprofundamento dos estudos de segurança, o conceito de objeto referente foi ainda revisto por outros teóricos críticos, que permitiram ainda maior abertura e flexibilidade para o conceito. Assim, para além de grupos ou coletividades, autores como Booth (2005) e Krause e Williams (1997).

Portanto, para que esse argumento seja desenvolvido, alguns passos devem ser tomados antes. A compreensão e, posteriormente, crítica à paz liberal exigem um entendimento prévio do liberalismo, não apenas como ideologia e tradição filosófica, mas também como retórica influente nas relações internacionais.

Por fim, o objetivo do presente capítulo é de se estabelecer as bases teóricas para o argumento a ser desenvolvido nessa pesquisa. Assim, serão expostas, em primeiro lugar, as bases do pensamento liberal, e sua influência nas Relações Internacionais, tanto na disciplina, quanto na retórica da política internacional. Em seguida, será apresentada uma operacionalização desses conceitos, na forma de uma fórmula para uma "paz liberal” a ser considerada para o decorrer da pesquisa. Em terceiro lugar, será discutida a evolução e definições para as operações de paz, para, por fim, apresentar as críticas à paz liberal que serão a ferramenta teórica para a argumentação proposta. Será discutido também qual a relação entre segurança e liberdade individual no liberalismo, para entender o que está de fato por trás do projeto liberal. Ou o que permite a liberdade do indivíduo? Como ela é colocada no liberalismo? Será adotado um ponto de vista crítico para tal discussão. Assim, o fio condutor dessa discussão será entender qual a posição e importância do indivíduo ao longo desse caminho, para depois, ao final desse trabalho, poder responder se ele é ou não o objeto referente da paz liberal.

\section{1}

\section{A Tradição Liberal nas Relações Internacionais}

A presente sessão tem por objetivo apresentar as bases e fundações do liberalismo como ideologia. Porém, não se pretende aqui discuti-lo em sua exaustão, tampouco recuperar suas tradições, com profundidade, desde o século XVIII. Mencionaremos as principais ideias de pensadores representativos de tal 
período como Locke, Bentham, Mill e Smith. Kant, por sua vez, será discutido com maiores detalhes ao decorrer do capítulo.

A exposição a seguir servirá para fundamentar a concepção de paz liberal, objeto de estudo da presente pesquisa. Assim, será explicado, de maneira breve, qual o cerne do liberalismo enquanto ideologia e qual sua origem. Em seguida, será discutido qual o lugar do liberalismo nas relações internacionais, tanto na disciplina quanto na política.

\subsection{1}

\section{O Liberalismo Clássico}

O paradigma do liberalismo, ou então o liberalismo clássico, remonta ao século XVIII, enquanto presente em ideias propostas por John Locke, Jeremy Bentham, John Stuart Mill, Adam Smith, e Immanuel Kant, sendo o último de maior relevância para o que se propõe, devido a sua ênfase ao internacionalismo. Cada um representa diferentes caminhos e vertentes que o liberalismo tomaria na História. Locke defendia o individualismo e a propriedade privada, e era um dos principais expoentes entre os teóricos contratualistas. A propriedade privada, por exemplo, era vista como algo que proporcionasse conforto e apoio aos homens, e, em última instância, bem-estar (Locke, 1689, p11).

The earth and everything in it is given to men for the support and comfort of their existence. All the fruits it naturally produces and animals that it feeds, as produced by the spontaneous hand of nature, belong to mankind in common; nobody has a basic right - a private right that excludes the rest of mankind - over any of them as they are in their natural state. But they were given for the use of men; and before they can be useful or beneficial to any particular man there must be some way for a particular man to appropriate them.

É algo que a natureza dá, como um presente, para o homem, para o seu próprio trabalho, e que ele pode ter como exclusivamente dele.

Bentham (1823, p.12), por sua vez, era um grande defensor de direitos individuais, como, por exemplo, das mulheres, além de ser um dos principais pensadores do utilitarismo, em conjunto com John Stuart Mill. O utilitarismo era definido como:

the principle that approves or disapproves of every action according to the tendency it appears to have to increase or lessen-i.e. to promote or oppose - the happiness of the person or group whose interest is in question.

(...) 
By 'utility' is meant the property of something whereby it tends •to produce benefit, advantage, pleasure, good, or happiness (all equivalent in the present case) or (this being the same thing)

Ou seja, utilidade estava intimamente conectada com bem-estar, com o conforto e felicidade do indivíduo per se.

Adam Smith é destacado por Doyle (2012) quanto a importância do comércio para o liberalismo, da economia de mercado e do livre comércio. Quando indivíduos têm a possibilidade de buscar seus próprios interesses, em um mercado sem a regulação de um governo, todos têm bem-estar. O bem-estar da sociedade, dessa maneira, seria agregado, ou seja, o conjunto do bem-estar de todos os indivíduos que saem ganhando no mercado. Os indivíduos podem exercer atividades que sejam produtivas e que gerem ganhos para eles sem que haja interferência do governo.

Por fim, Kant, "a liberal republican who calls for a demanding internationalism that institutes peace among fellow liberal republics (Doyle, 2012, p. 5)”. Kant será desenvolvido com maiores detalhes ao longo do capítulo.

Pois, se Doyle desenvolverá sua argumentação sobre a existência de uma paz separada entre os estados liberais, nesse sentido, Kant se destacará como um dos pensadores mais influentes para essa ideia.

Com base nas obras clássicas dos autores citados acima, o que se entende, de modo amplo, por liberalismo, se traduz em um retrato de princípios e instituições, cujas características comuns seriam: a liberdade dos indivíduos, o direito à propriedade privada, a participação política, igualdade jurídica dos cidadãos, a representação democrática e a crença nas instituições. De modo que os primeiros valores apresentados culminariam na criação de instituições para protegê-los. Assim, o que se observa é que um dos elementos que constituem a essência desse paradigma é a importância do indivíduo, na crença de que sua liberdade, sobretudo moral, deve ser garantida. Dessa maneira, devido à preocupação em preservá-la, se originaram as instituições, e, consequentemente, os diretos individuais protegidos pela lei e pelo estado de direito (Doyle, 2012).

Doyle (2012), a despeito de tais direitos, verifica que existem três vertentes que os conjugam. São elas: a liberdade da autoridade arbitrária, ou a liberdade negativa; a proteção das capacidades e oportunidades para a liberdade, ou a liberdade positiva; e, por fim, a participação e a representação democrática. 
Dessa maneira, o que seria tido como o maior dilema para o liberalismo se basearia em qual seria a melhor maneira de se conciliar esses três direitos, de modo que assim um grupo de indivíduos racionais se organizaria, tal como identificado na obra de Kant, por Doyle.

Será em Kant também que Doyle encontrará o embrião do liberalismo nas relações internacionais, conforme será tratado na próxima sessão.

\subsection{2}

\section{O Liberalismo e as Relações Internacionais}

A obra de Kant, A Paz Perpétua, sob o ponto de vista de Doyle (2012), poderia ser tida como uma fórmula alternativa os estados-nação autárquicos e a soberania. A paz internacional seria possível a partir da existência das liberdades no âmbito doméstico, da participação política, e de atividades comerciais - ou seja, valores essencialmente fundados no liberalismo, conforme já foi apontado na sessão anterior. Os estados seriam republicanos, sendo que a definição de república, para o filósofo, se sustenta na igualdade jurídica dos sujeitos, através de um governo representativo e com separação de poderes. Dessa maneira, ressalta Kant, a tirania é evitada, pois estão todos os indivíduos sujeitos as mesmas leis, e não há como modifica-las. Pois seria necessário um consenso entre os cidadãos para ir à guerra, ao contrário do que aconteceria se fosse um tirano governando. Aponta-se aqui a importância do desenvolvimento do direito internacional, que Kant desenvolve ao longo de sua obra: é ele quem garante o respeito mútuo nas relações entre os diferentes estados.

Porém, a noção apresentada por Kant não envolvia a existência de um governo mundial, mas sim das relações possíveis e pacíficas entre as repúblicas, que compartilhariam dos mesmos valores. Kant crê em uma noção de progresso, na qual a humanidade tende a se racionalizar cada vez mais e se aproximar do ideal, ou seja, de relações completamente pacíficas, ou da paz perpétua, ao longo do tempo (Kant, 2004). Essa noção que será recuperada através do conceito da paz democrática, ou da existência de uma paz separada entre os estados liberais, nas palavras de Doyle (2012). Assim, ao se democratizar um país, a paz seria disseminada, e construiria uma nova ordem mundial pautada pelos valores 
liberais, pela liberdade, pela democracia, e prosperidade. Conforme Doyle (2012) levanta, diversas políticas externas (sobretudo de países ocidentais) se basearam nessa concepção, e promoveram a liberdade e democracia e, através de, sobretudo, operações de peacebuilding, conforme será discutido mais adiante. Porém, ele também ressalta que estados liberais também podem ser agressivos, especialmente com relação a estados não liberais (Doyle, 2012).

A despeito do liberalismo nas Relações Internacionais, a tradição se faz presente tanto no âmbito acadêmico quanto no político, e é ecoada constantemente através da retórica de líderes ocidentais. Doyle (2012) atenta para o fato de que, em relação as outras teorias do mainstream das Relações Internacionais, o liberalismo emerge, em princípio, como uma teoria de cunho doméstico, e não internacional. Diferente do realismo, que nasce como uma escola estritamente ligada as Relações Internacionais, e que não aborda quaisquer aspectos internos dos estados.

A presença do paradigma liberal nas Relações Internacionais se evidencia, sobretudo, na crença de que experiência da cooperação entre estados engendraria mais comportamentos cooperativos entre eles em momentos de incertezas políticas. Tais atitudes se mostrariam mutuamente benéficas, de modo que estados liberais tenderiam a se aliar entre si. Desse modo, um dos principais exemplos seria o livre comércio, que promoveria a paz e traria um senso de segurança mútua (Doyle, 2012).

O livre comércio, por exemplo, promoveria a paz através de um senso de segurança mútua. Assim, estados liberais tendem a se aliar com outros estados liberais. Porém, o autor argumenta-se também que, devido a tais motivos, os estados liberais não necessariamente seriam pacíficos em face de outros regimes, sobretudo os de caráter não democrático-, de modo que os motivos de agressão seriam fundados no próprio liberalismo (Doyle, 2012).

Os estados liberais teriam obtido sucesso ao criar uma zona de paz e de cooperação, embora tenham falhado em suas políticas externas com relação a estados não pertencentes desse mundo. Assim, para esses estados, a promoção de tais princípios liberais deveriam sempre guiar suas políticas: a saber, assegurar necessidades humanas básicas, direitos civis, democracia, expandir o escopo e efetividade da economia de mercado, todos eles valores que sustentariam a sensação de bem-estar para a sociedade, na medida em que todos os indivíduos 
estariam ganhando conjuntamente, ainda que se conjuguem de forma a constituir um sistema saudável principalmente para as potências ocidentais - cujas economias baseadas no liberalismo, ou, então, neoliberalismo, necessitam da expansão desse sistema para o bem-estar de suas próprias populações.

Em outro trabalho, em que o autor se debruça sobre a presença do liberalismo nas relações internacionais, Doyle (1986) parte da ideia de que existem três tipos diferentes de liberalismo, e que cada um deles é atribuído a um teórico distinto. Cada vertente apontaria para comportamentos políticos de diferentes estados, em diferentes períodos.

O primeiro a ser discutido, o liberalismo kantiano, ou o internacionalismo liberal seria, segundo o autor, a abordagem liberal de maior representatividade. Pois, para Kant, os estados liberais seriam pacíficos em suas relações com outros estados liberais. Assim, existiria uma "paz separada" que se constituiria entre eles. Além dos indivíduos serem capazes de apreciar a igualdade moral existente entre eles, os laços econômicos entre tais estados também são muito fortes, interdependentes entre si. Por outro lado, os laços com outros estados seriam frágeis. Por fim, a paz perpétua kantiana se pautaria através dos seguintes artigos, presentes em sua obra que se tornou um grande legado: 1) Constituições de todos os estados devem ser republicanas ${ }^{1}$; 2) Estabelecimento de uma união pacífica entre os estados através de acordo; 3) Lei cosmopolita operaria em conjunto com união pacífica.

Outra vertente estudada por Doyle (1986) seria o pacifismo liberal, atribuído a Schumpeter, e que seria baseado na interação entre capitalismo e democracia. Elas seriam as forças responsáveis por levar a paz. A valorização do indivíduo é central: ele é democratizado, individualizado e racional. Existe, nessa concepção, um contraponto ao imperialismo: o último desaparecia em virtude do desenvolvimento do capitalismo.

Por fim, outra possível corrente seria a atribuída a Maquiavel, ou o imperialismo liberal, que, segundo Doyle (1986), é frequentemente praticado pelos liberais; repúblicas não seriam formas de governos pacifistas, porém é a melhor maneira para a expansão imperial. Tal expansão, por sua vez, garantiria a sobrevivência do Estado. A república maquiavélica não é uma democracia, mas é

1 A noção de república, para Kant, era de um sistema no qual houvesse separação de poderes, constitucionalismo, e representatividade (Kant, 2004; Doyle, 2012). 
caracterizada pela igualdade social, liberdade popular e participação política. Para ele, democracia se degeneraria e se tornaria uma tirania. Seu questionamento final levanta se as intervenções empreendidas pelos Estados Unidos teriam sido baseadas nessa última concepção apresentada.

Com base no que foi apresentado, entenderemos o liberalismo como um conjunto de valores e instituições, que, para análises futuras, se centrará nos seguintes conceitos: (1) a centralidade do indivíduo; (2) sua liberdade e (3) bemestar; (4) o livre comércio e (5) a economia de mercado; (6) a participação política e (7) a representação democrática; e, por fim, (8) a crença nas instituições. Tais características servirão para que possamos observá-las na paz liberal e em sua crítica subsequente.

\section{2.}

\section{A Paz Liberal}

Uma das principais bases da paz liberal, objeto de estudo desse trabalho, seria a exportação do modelo liberal tradicional. Ou seja, um modelo que seria baseado na centralidade do indivíduo, sua liberdade e bem-estar, o livre comércio e a economia de mercado, a participação política e a representação democrática, e, por fim, a crença nas instituições. É notável sua frequência na retórica da política mundial, tal como apresentado por Doyle (2012), em sua introdução da obra Liberal Peace: Selected Essays:

Liberal peace is definitely part of the rhetoric of foreign policy. Indeed, we have often been told that promoting freedom produces peace. At the US Republican Convention is 2004, President George W. Bush told "young men and women" in the Middle East and "...reformers and political prisoners and exiles" everywhere "...that their dream of freedom cannot be denied forever... As freedom advances, heart by heart, and nation by nation, America will be more secure and the world more peaceful." [...] In a speech before the British parliament in June of 1982, President Reagan proclaimed that governments founded on a respect for individual liberty exercise "restraint" and "peaceful intentions" in their foreign policy. He then (perhaps ironically) announced a crusade for freedom, and a campaign for democratic development. And not just Republicans, President Clinton made "Democratic Enlargement" the doctrinal centerpiece of his administration's foreign policy in the 1990s. And of course, these ideas were the hallmark of Woodrow Wilson's foreign policy and of the foreign policies of many other liberals (Doyle, 2012, p. 1). 
O parágrafo $\$ 81$ do relatório Agenda for Peace também atesta a presença da paz liberal e democrática no discurso político:

\begin{abstract}
Democracy within nations requires respect for human rights and fundamental freedoms, as set forth in the Charter. It requires as well a deeper understanding and respect for the rights of minorities and respect for the needs of the more vulnerable groups of society, especially women and children. This is not only a political matter. The social stability needed for productive growth is nurtured by conditions in which people can readily express their will. For this, strong domestic institutions of participation are essential. Promoting such institutions means promoting the empowerment of the unorganized, the poor, the marginalized. To this end, the focus of the United Nations should be on the "field", the locations where economic, social and political decisions take effect. In furtherance of this I am taking steps to rationalize and in certain cases integrate the various programmes and agencies of the United Nations within specific countries (ONU, 1992, § 81).
\end{abstract}

O modelo se baseia na exportação da democracia e do cerne dos valores liberais, a saber, liberdade do indivíduo, seu bem-estar, livre comércio e economia de mercado, participação política e representação democrática, e crença nas instituições, e também fundamenta o sistema de governança global composto por diversas organizações internacionais, o que inclui, por exemplo, a própria ONU, e as instituições financeiras internacionais (IFIs).

Doyle (2012) baseia sua noção de paz liberal no pensamento de Kant, a partir do que se acreditava ser a paz separada entre os estados liberais. Enquanto seu entendimento sobre liberalismo se resume em um conjunto de valores e instituições que apresentariam características comuns, dentre os mais importantes, a liberdade individual, a participação política, a igualdade e oportunidades iguais para todos, no âmbito internacional, o que ele chama de liberalismo internacional se pautaria, então, por ser “(...) an attempt to promote these principles and institutions across national borders and apply variations thereof to relations among states. (Doyle, 2012, p, 206).”

Desse modo, sua noção de paz liberal, para além da existência de uma paz separada entre os estados liberais, se estende também para a promoção desses valores do cerne das tradições liberais para outros estados ao redor do mundo - o que, consequentemente, levaria a uma extensão da paz separada tal como havia sido definida por Kant. O próprio Kant teria dito, por exemplo, que países liberais poderiam entrar em algum conflito caso houvesse desejo popular para tal, a parte de conflitos com outros sistemas políticos (Kant, 2004; Doyle, 2012). Mas seriam 
apenas repúblicas que teriam a possibilidade para consenso, e seriam capazes de reconhecer a confiabilidade de outras repúblicas - e que, por fim, entenderiam o risco de outros sistemas políticos serem mais agressivos, em especial regimes autocráticos. Democracias liberais também entendem a importância da cooperação entre si e de como podem obter benefícios mútuos através dela, que, conforme levantado por Doyle (2012), é de alto nível. O progresso que teria ocorrido desde os tempos de Kant até hoje, sobretudo em relação a participação política, estabelece uma das bases morais da paz liberal. Doyle (2012, p. 167) resume que "[t]he key to the liberal argument is the claim that by establishing domestic liberty, political participation, and Market Exchange one can have the international payoff of peace as well'. Promover a democracia e aumentar a zona democrática - a paz separada - eventualmente se tornaram peças chaves na retórica também.

Outro autor relevante para a teoria da paz democrática, Bruce Russett (1993), especula acerca do pensamento de Kant a respeito da paz democrática, e conduz pesquisa em vistas de se comprovar com maior rigor o fato de que as democracias nunca teriam entrado em conflito entre si:

To the degree that countries once ruled by autocratic systems become democratic, a striking fact about the world comes to bear on any discussion of the future of international relations: in the modern international system, democracies have almost never fought each other. This statement represents a complex phenomenon: (a) Democracies rarely fight each other (an empirical statement) because (b) they have other means of resolving conflicts between them and therefore do not need to fight each other (a prudential statement), and (c) they perceive that democracies should not fight each other (a normative statement about principles of right behavior), which reinforces the empirical statement. By this reasoning, the more democracies there are in the world, the fewer potential adversaries we and other democracies will have and the wider the zone of peace (Russett, 1993, p. 4).

Russett (1993), inclusive, sobre Woodrow Wilson, enxerga uma clara influência de Kant nos seus Catorze Pontos, pela sua crença na progressividade na política, e pelas ideias presentes em seu texto pautadas pelo cosmopolitanismo e união pacífica. As leis cosmopolitas, por exemplo, incorporariam as ideias de comércio livre e internacional (Russett, 1993, p. 4).

Seu estudo foi bastante rigoroso metodologicamente, e vários itens foram avaliados para averiguar a validade da teoria da paz democrática. Ele comparou, também através do tempo, tal como de que maneira se dava a relação entre 
democracias antes das grandes guerras, no período entre guerras, e depois. Por exemplo, o autor levantou que guerras ou embates ocorrem sobretudo devido a conflito de interesses. Um dos principais motivos seria quanto a fronteiras. Assim, Russett (1993) descobriu que, por exemplo, entre as décadas de 1920 e 1930, de fato poucas democracias tinham fronteiras entre si, então por esse motivo não entrariam em conflito. No entanto, ao observar as décadas que se sucederam, chamou a atenção o fato de que, mesmo que o número de democracias tenha aumentado e que passaram a ter fronteiras entre si, continuaram a não entrar em conflito. Esse fenômeno de expansão democrática e de paz entre elas se consolidou durante a década de 1980, e, em 1990, já era parte essencial da retórica dos líderes americanos, por exemplo.

Com relação aos seus conceitos e definições, Russett (1993) se apropria da concepção de Dahl de democracia, ou conforme o referido autor denomina, poliarquias, como:

[I]dentified with a voting franchise for a substantial fraction of citizens, a government brought to power in contested elections, and an executive either popularly elected or responsible to an elected legislature, often also with requirements for civil liberties such as free speech (Russett, 1993, p. 16)

Além disso, Russett (1993), através de sua obra, estabelece as seguintes proposições acerca da paz democrática. A primeira diz respeito ao fato de que o próprio sistema político das democracias restringem a possibilidade de entrarem em conflito com outras democracias. No entanto, verifica-se que, não necessariamente significa que democracias são absolutamente pacíficas, pois entram em conflitos com outros sistemas políticos. Ele compara também que: "democracies are less likely to use lethal violence toward other democracies than toward autocratically governed states or than autocratically governed states are toward each other. (Russett, 1993, p. 11)”. Outra proposição seria de que os atributos do sistema político democrático de fato resultam em paz, e que, segundo sua pesquisa, que envolveu até mesmo métodos quantitativos, aponta-se que de fato não houve conflito direto entre democracias na contemporaneidade.

Em texto de 1995, Ido Oren (1995) entende a paz democrática como uma concepção essencialmente americana. As tais outras democracias, que ao final, comporiam a dita paz democrática, representariam e refletiriam os valores americanos, ou, ao menos, se aproximariam do que se consagraria como um modelo de democracia que deveria ser seguido para que se estabelecesse a paz. É 
válido ressaltar também que o autor defende que não se trata de uma concepção estática: reflete o momento e os valores em voga, de acordo com o momento histórico em questão. É, sobretudo, relacionada a auto-imagem que os Estados Unidos pretendem projetar.

Para além de uma definição de paz liberal que se baseie na relação entre os estados liberais e a existência de uma comunidade pacífica entre eles, o que servirá de base para a presente pesquisa bebe na fonte dos críticos desse modelo, que creem na existência de um projeto político hegemônico, o qual se pauta por reforçar as estruturas de poder já existentes. Além disso, a exportação de tal modelo através dessa rede de governança só foi possível e só teve seu advento a partir dos anos 1990, com o final da Guerra Fria e suas subsequentes mudanças, sobretudo nas características dos conflitos que emergiriam após a bipolaridade.

\section{3}

\section{Definições Críticas para a Paz Liberal}

A despeito das definições críticas para o modelo da paz liberal, e que serão fundamentais para a argumentação a ser desenvolvida, o primeiro autor a ser tratado é Mark Duffield (2001). Ele erige seu argumento e sua definição sobre a paz liberal baseando-se na existência de um complexo político articulador de um projeto de governança, no qual o Sul global e seu desenvolvimento representam ameaças constantes a segurança internacional pós Guerra Fria. Assim, Duffield (2001, p. 11) verifica "[i]t reflects the existing consensus that conflict in the South is best approached through a number of connected, ameliorative, harmonising and, especially, transformational measures". É, desse modo, um projeto político radical, que visa transformar sociedades entendidas como disfuncionais em sociedades estáveis. O que se argumenta é que a paz liberal é, então, o projeto, a ser implementado através de todo esse complexo sistema, nas fronteiras entre Norte e Sul e suas instabilidades, através da resolução e conflitos, reconstrução de sociedades e estabelecimento de economias de mercado funcionais de modo que conflitos e suas recorrências sejam evitados no futuro. Podemos observar, portanto, que em Duffield (20010, a respeito de sua visão de paz liberal como um projeto radical, que valores liberais como os mencionados anteriormente se 
sobrepõe a outros, por exemplo, vemos como o indivíduo, na verdade, não é central a esse projeto.

Além disso, dentro de sua literatura, não basta definir a paz liberal apenas baseada nas ações empreendidas pelas organizações internacionais, mas ela deve ser entendida também por incorporar:

(...) new or political humanitarianism that lays emphasis on such things as conflict resolution and prevention, reconstructing social networks, strenghtening civil and representative institutions, promoting the rule of law, and security sector reform in the context of a functioning market economy (Duffield, 2001, p. 11).

Ou seja, a paz liberal abarca em seu projeto a maioria dos itens do escopo dos valores tradicionais do liberalismo, e ela se propõe a implementá-los através do peacebuilding.

Além disso, vale acrescentar que uma nova relação com o humanitarismo emergiu. O humanitarismo adquire novas funções no período pós Guerra Fria devido a todas as mudanças que esse período trouxe consigo. Desse modo, a mudança no escopo de atuação do humanitarismo na década de 1990 é reflexo direto da mudança de foco sobre o que é tido como ameaça à segurança internacional, ou seja, a securitização do sul. Entra em voga o discurso, e, por conseguinte, a prática, de que o subdesenvolvimento é quem traz instabilidade, logo, insegurança; o subdesenvolvimento torna-se um perigo, algo que deve ser tratado, evitado, para que conflitos não ocorram. É a partir de então que emerge a articulação entre segurança e desenvolvimento, primeiro, porque as guerras deixaram de acontecerem entre estados, e, segundo, porque houve uma erupção de conflitos civis após o final da bipolaridade.

Outro ponto de relevância levantado por Duffield (2001), concerne ao caráter não-territorial da paz liberal. Ela é baseada em relações que ocorrem através de tais complexas redes de governança internacionais, supracitadas, que, em conjunto com esse novo humanitarismo, são características por englobar uma variedade de diferentes atores envolvidos.

Já Pugh (2009) aponta também para como ela transparece através do discurso, por exemplo, de Bush: "We seek a just peace where repression, resentment and poverty are replaced with the hope of democracy, development, free markets, and free trade". (Pugh et al, 2009, pg 2).

Como observado, o discurso de Bush reproduzido acima compreende todo conjunto de valores básicos do liberalismo. Ele menciona liberdade política, 
representação democrática (implementação da democracia), livre comércio e livre mercado. Ele acrescenta que é necessário o desenvolvimento para que tais características sejam plenamente alcançadas.

Roland Paris (2004), por sua vez, propõe as bases para a paz liberal remontando ao discurso de Woodrow Wilson: pois, para ele, liberalismo, como remédio ao conflito, não seria algo tão recente quanto os anos 1990. Wilson já dizia que, para que a paz perdurasse, a estabilidade deveria ser garantida, o que implicaria, portanto, em assegurar os direitos dos indivíduos e promover a democracia para novas e pequenas nações, além da autodeterminação. Ou seja, para Woodrow Wilson, a centralidade do indivíduo era essencial.

Por fim, Oliver Richmond (2005) propõe a paz liberal como uma institucionalização de normas que compõem uma estrutura política para a paz. A política de exportação da democracia como padrão para evitar conflitos foi universalizada como estratégia para colocar um fim às guerras. Ou seja, os dois valores liberais que transparecem com maior clareza para o autor seriam a crença nas instituições, principalmente internacionais, e a representação democrática.

A despeito dos conflitos, dentro desse contexto, seriam tidos como disfuncionais, e que podem ser modificados por meio da adoção de abordagens mobilizadas como corretas sociais, políticas e econômicas. Porém, tal estratégia é posta em prática através da hegemonia dos estados mais poderosos, e se solidifica como uma forma de governança global (Richmond, 2012; Duffield, 2001).

O projeto em questão fica visível na prática com a expansão da agenda da ONU, e, em consequência, da ampliação do escopo das operações de paz (Doyle \& Sambanis, 2006). Bellamy e Williams (2011, p. 24) afirmam que as operações de paz são pautadas pela paz liberal pois buscam criar uma paz estável, através da promoção dos princípios do projeto. Eles ressaltam que isso é mais visível nas operações de peacebuilding e em suas tentativas de se implementar a paz dentro de um estado, o que ocorre através da democracia e da economia de mercado. A próxima sessão focará em discutir de que maneira tais operações evoluíram e criaram as bases para o estabelecimento do peacebuilding como carro chefe das operações pós década de 1990. 


\section{4}

\section{A Evolução das Operações de Paz}

A importância de se discutir as operações de paz para o presente trabalho se dá na medida em que elas representam a tentativa de se implementar a paz liberal em sociedades que acabaram de atravessar um conflito, sobretudo em suas últimas gerações.

Em busca de uma definição para operações de paz, em primeiro lugar, deve ser apontado que não há um consenso, nem entre autores, nem entre organizações internacionais. Existem, no entanto, pontos em comum que permitem com que uma definição geral seja formulada. Porém, dentre o que já há de disponível na literatura, elas refletem as convicções de quem as formulou (Bellamy \& Williams, 2011).

Bellamy e Williams (2011, p. 3) levantam que, na Carta da ONU, não constam os termos peacekeeping ou operações de paz. No entanto, foi apenas em 1992, no relatório Agenda for Peace, que o então secretário geral Boutros Boutros-Ghali se preocupou em estabelecer definições e conceitos para as operações de paz (ONU, 1992, § 20):

Preventive diplomacy is action to prevent disputes from arising between parties, to prevent existing disputes from escalating into conflicts and to limit the spread of the latter when they occur.

- Peacemaking is action to bring hostile parties to agreement, essentially through such peaceful means as those foreseen in Chapter VI of the Charter of the United Nations.

- Peace-keeping is the deployment of a United Nations presence in the field, hitherto with the consent of all the parties concerned, normally involving United Nations military and/or police personnel and frequently civilians as well. Peacekeeping is a technique that expands the possibilities for both the prevention of conflict and the making of peace (ONU, 1992, § 20).

$\S 21$. The present report in addition will address the critically related concept of postconflict peace-building - action to identify and support structures which will tend to strengthen and solidify peace in order to avoid a relapse into conflict. Preventive diplomacy seeks to resolve disputes before violence breaks out; peacemaking and peacekeeping are required to halt conflicts and preserve peace once it is attained. If successful, they strengthen the opportunity for post-conflict peace-building, which can prevent the recurrence of violence among nations and peoples. 
Na obra Understanding Peacekeeping, a definição apresentada pelos autores é de que peace operations são “(...) one general type of activity that can be used to prevent, limit and manage violent conflict as well as rebuild its aftermath (Bellamy \& Williams, 2011, p. 18).” Ou seja, é uma definição genérica que contempla os aspectos comuns de todas elas.

Para Pugh (2004), a conceptualização das operações de paz seriam estreitas e visariam a resolução de problemas, tal como proposto por Cox. As operações seriam instrumentos ou ferramentas meramente administrativas, alocadas para medicar disfuncionalidades da ordem global, sob as bases de um framework de imperialismo liberal.

A teoria crítica, por outro lado, pretende expor as injustiças que emergem das ideologias tidas como incontestáveis. Analisa-se o potencial para transformação estrutural e para a emancipação, ao invés de reforçar os imperativos que determinaram a ortografia do que já tem sido escrito. Pugh (2004) se apropria tanto de Duffield quanto de Cox para traçar seu argumento.

No que concerne à obra de Duffield, Pugh (2004) se vale da análise de que áreas periféricas não correspondem mais a uma ordem vestfaliana, operando através de redes de economias "shadow".

O argumento central de Pugh (2004) é que a visão de peacekeeping na governança global não é neutra, mas serve "the purpose of an existing order within which problem-solving adjustments can occur" (Pugh, 2004, p. 41). A ordem não é questionada e é aceita como a realidade, o que reforça valores e estruturas hegemônicas.

Para traçar a evolução das operações de paz, os autores recuperam seus antecedentes, que datam das tentativas de administrar o colapso do Império Otomano. Em 1913, houve a criação da Albânia e a absorção de Kosovo a Sérvia. Para a última, foram enviados 2000 soldados de uma força de administração internacional. Já para a primeira, foi uma missão multinacional de caráter humanitário (Pugh, 2004).

O período entre guerras, e o momento imediato após a Segunda Guerra Mundial foram marcados por instâncias de governança multinacional e de forças ad hoc, sobretudo para monitoramento e supervisão de casos de transição (por exemplo no caso de Schleswig-Holstein, em 1920, e Grécia em 1947-51). 
Diehl (2008), por sua vez, entende que o início de tal processo evolutivo quase coincide com a história das instituições de segurança coletiva. A primeira força de observação de paz internacional teria sido em Saar, conforme relatado:

The League of Nations action in the Saar may be the first true example of an international peace observation force. Yet, the conditions under which the operation functioned were extraordinary, and indeed helped contribute to the success of the mission. The Saar, lying between France and Germany, was to be an internationally administered territory for a period of years following World War I, at which time a plebiscite would decide the final disposition of the area, with options including unification with France or Germany. Thus, the usual problem of obtaining permission of the host country for the stationing of an international force was not an issue in this case: the League was the equivalent of the host state. This became particularly important when Germany made several hostile gestures toward the establishment of the force. The French were also less than fully cooperative, perhaps believing (correctly) that the territory would ultimately be returned to Germany. The international administration of territories would be repeated decades later by the UN in East Timor and NATO in Kosovo (Diehl, 2008, p. 35).

A tropa enviada era de composição britânica, italiana e de outros países europeus; a novidade era a maneira pela qual foi conduzida, pela Liga das Nações e por dotar de um comandante escolhido especificamente para a missão. A força deveria ser usada ao mínimo, e a tropa deveria patrulhar o território e assegurar que responderiam apenas em caso de emergência. Embora a Liga das Nações tenha fracassado, a missão obteve sucesso. Esse molde de missão de observação inauguraria as guidelines que, mais tarde, serviriam como base para as operações de peacekeeping das Nações Unidas.

Para que um novo fracasso fosse evitado na fundação da ONU, foi instituído o Conselho de Segurança e seu sistema de vetos, que acreditava-se que seria a melhor maneira de se evitar novas grandes guerras. No entanto, com o advento da Guerra Fria, esse instrumento ficou, por muitos anos, congelado. De modo que a primeira grande ação coletiva foi apenas voltada para a Guerra da Coréia, que ocorreu em 1953 (Diehl, 2008).

A primeira operação de paz, no entanto, foi na Grécia, logo após o final da Segunda Guerra Mundial. Foram instalados postos nas fronteiras gregas com Albânia, Iugoslávia e Bulgária, e as tropas ficaram responsáveis por inspeções, e para assegurar que as forças rebeldes não recebessem mantimentos (Diehl, 2008).

Dentre as discussões correntes sobre as operações de paz, são comuns as tentativas de sistematizá-las e organizá-las sob critérios arbitrários, que 
correspondem, normalmente, a relações profundas com a política em si que Bellamy (2004) critica. Tais sistematizações são de cunho didático, embora tenham inferências e implicações políticas.

Portanto, em conjunto com Bellamy e Williams, se propõe uma nova taxonomia que seja baseada no papel que cada uma das missões a serem enquadradas cumprem dentro da política mundial. A saber, determinam os seguintes tipos de missões de paz:

Peacekeeping tradicional, que seriam operações cuja finalidade é de se criar um espaço para que a resolução de disputas políticas seja possível; Administração de transição, ou seja, operações em que há suporte para a implementação de resoluções políticas previamente acordadas entre as partes; peace enforcement, que implica em impor as determinações do Conselho de Segurança das Nações Unidas; wider peacekeeping, que seriam as operações cuja finalidade seriam mais ampla no sentido de se abarcar funções humanitárias em meio a situações frágeis de paz; e, por fim, peace support operations, missões de escopo mais amplo, que apoiam a implementação de uma democracia liberal e são multifacetadas por conjugarem componentes civis e militares na atribuição de tarefas (Bellamy, 2004, p. 22)

Outros autores, em busca de uma sistematização mais didática, sugeriram a categorização das operações em gerações, de acordo com os diferentes paradigmas que cada uma representaria.

Após a criação da ONU, a primeira operação de paz a ser estabelecida foi a United Nations Truce Supervision Organization, no Oriente Médio. Porém, apenas em 1956, na disputa em Suez, que foram enviados, pela primeira vez, os capacetes azuis (Doyle \& Sambanis, 2006; Pugh, 2004; Bellamy \& Williams, 2011). Tais primeiras operações, chamadas de peacekeeping tradicional, eram ditas neutras e aconteciam somente após um acordo de cessar-fogo. Não era permitido o uso da força às forças da ONU, salvo sob alegação de legítima defesa. (Bellamy \& Williams, 2011; Pugh, 2004).

As operações de peacekeeping seriam enviadas sempre sob provisões do capítulo VI da Carta da ONU, desde que haja consentimento do estado que irá receber a missão, que haja imparcialidade, e o mínimo uso da força. As tropas eram enviadas para separar e conter os combatentes após um processo de cessar fogo, de modo que outros possíveis atos que pudessem desencadear em um 
conflito novamente seriam inibidos. É feita também a prevenção de violações do tratado de cessar fogo, e, por fim, são responsáveis por criarem condições para que o conflito seja resolvido pacificamente (Diehl, 2008; Bellamy \& Williams, 2011). Além disso, Diehl (2008) acrescenta que peacekeeping seria um novo uso para soldados, em papéis não tradicionais, pois seriam coordenados por organizações internacionais, e não governos nacionais.

Por fim, é importante fazer menção ao caráter apolítico das operações de peacekeeping. Primeiro, porque, segundo Roland Paris (2004), as operações respeitavam a proibição feita na Carta da ONU sobre intervenções no âmbito doméstico. Além disso, ocorriam dentro do contexto da Guerra Fria, de modo que a ONU não poderia tomar partido e deveria se manter neutra. Não havia a possibilidade de se promover determinado modelo de governança doméstica para os estados em questão. Havia também a preocupação, por parte das duas grandes potências, em se manter a integridade de suas zonas de influência e de seus aliados, além do fato também de que não necessariamente os próprios estados receptores estavam dispostos a receber missões cujo escopo seria maior do que o peacekeeping se pretendia.

A relevância de tais missões é de que evoluíram para operações de paz, mais complexas, abarcando um escopo de funções muito mais amplo (Diehl, 2008). Doyle e Sambanis (2006) as consideram missões de primeira geração.

Com o final da Guerra Fria, o Conselho de Segurança, antes congelado pelos incessantes vetos entre União Soviética e Estados Unidos, passou a atuar de maneira mais ativa, bem como os estados membros passaram a cooperar mais intensamente, conferindo à ONU uma mudança em seu direcionamento. As operações de paz passaram a ser seu carro chefe diante da erupção de novos conflitos. Assim, além de um aumento na quantidade de operações empreendidas pela ONU, Bellamy e Williams (2011, p. 93) defendem que outras duas importantes transformações ocorreram: houve uma mudança normativa, ou seja, alguns atores acreditavam que o escopo das operações deveria ser ampliado de modo que a concepção de soberania abarcasse uma preocupação maior com o indivíduo, abrindo possibilidade para ação da comunidade internacional; e, por fim, houve uma mudança no âmbito qualitativo, que aliava os objetivos tradicionais do peacekeeping com a ajuda humanitária, programas de reconstrução, transformando-as em missões complexas e extensas. 
Tais mudanças foram codificadas a partir do relatório intitulado $A n$ Agenda for Peace, publicado em 1992, de autoria de Boutros-Boutros Ghali, então secretário-geral das Nações Unidas. Os guidelines revelavam que as missões deixariam de ser apenas para monitoramento, e conferiam permissividade para mais ação por parte da própria ONU no campo. O Departamento da ONU para Operações de Paz (DPKO) foi criado logo em seguida (Bellamy \& Williams, 2011, p.101).

Assim, as operações de segunda geração emergiriam com base nesse contexto. Também categorizadas como operações multidimensionais por Doyle e Sambanis (2006), seriam missões cujos mandatos, de maior complexidade, abrangeriam, após o final de guerras civis, a implementação de acordos que buscassem a construção das bases de uma paz autossustentável. Isso implicaria na organização de eleições, em processos de desarmamento, ajuda humanitária, assistência a refugiados, o estímulo a cooperação social e econômica entre as partes, a construção de confiança entre elas, e o desenvolvimento de capacidades e de infraestrutura. $\mathrm{O}$ consentimento das partes ainda era um dos pilares de tais missões. Alguns exemplos seriam as missões em El Salvador, Moçambique e Camboja (Doyle \& Sambanis, 2006).

As operações de terceira geração, por sua vez, diferem de operações de peacebuilding ou peacekeeping, o peace enforcement, termo que deriva do Agenda for peace, se caracterizaria pelo uso da força autorizado sob capítulo VII, ao passo que missões de peacekeeping que ocorrem sob capítulo VI. Objetivam, em última instância, a proteção do indivíduo em situações de emergência humanitária - ou seja, um valor central ao liberalismo, conforme já foi demonstrado, e que aqui começa a transparecer em meio a retórica das operações de paz. Seus mandatos também preveem a execução de processos de cessar fogo (Doyle \& Sambanis, 2006). Tais missões, conforme citado por Diehl (2008), envolvem o uso de capacidades militares, de modo que se aproximam de operações militares convencionais. Outra diferença é que tais missões não envolvem o consentimento das partes. São de caráter mais coercitivo em relação as outras, pois é através do uso da força que se implementa a paz, nesses casos. São feitas imposições para proteção dos civis, tais como corredores humanitários. O modelo de tais missões se baseia no que ocorreu, sobretudo na Bósnia (Doyle \& Sambanis, 2006) 
No entanto, Bellamy e Williams (2011) ocupam parte de seu trabalho descrevendo de que maneira muitas dessas missões fracassaram, o que acarretou em um período de retração por parte da ONU até o final da década de 1990, e foi apenas com a intervenção em Kosovo que a organização estabeleceu novas bases para suas operações. Os principais fracassos foram Ruanda, Srebrenica, e Somália, nos anos de 1994, 1995, e 1992, respectivamente.

Em 2000, foi lançado o relatório Brahimi, que se propôs a fornecer uma revisão das operações de paz com base nas lições aprendidas com tais erros supracitados (Bellamy \& Williams, 2010; ONU, 2000).

O relatório é aberto com o reconhecimento dos fracassos, relembrando qual a missão da ONU e sobre qual princípio ela foi fundada: "to save succeeding generations from the scourge of war (ONU, 2000, §1)"; reconhece-se também os fracassos institucionais, e, ainda, alerta para a nova demanda de operações de paz.

O painel responsável pela elaboração do documento teve como tarefas identificar os pontos fracos das operações, para que pudessem, em seguida, fazer recomendações através do documento final (Bellamy \& Williams, 2011).

Dentre as premissas estabelecidas sobre as quais se baseiam as recomendações, destacam-se: maior comprometimento e responsabilidade por parte dos estados membros pela manutenção da segurança e da paz, que haja mais foco na prevenção de conflitos, que exista esforço e rapidez maior na coleta e acesso as informações para os processos de tomada de decisão, por exemplo, para identificar se um genocídio está ocorrendo ou não, a aderência aos direitos humanos e ao direito humanitário, maior integração nos processos de paz e operações, mais planejamento institucional, e, um dos elementos mais importantes, que as respostas sejam mais eficientes, para evitar ocasiões tais como Ruanda (ONU, 2000, §6).

Em 2008, a ONU publica um novo relatório propondo uma nova doutrina para guiar as operações de paz futuras, intitulada Capstone Doctrine. Conforme exposto no próprio documento, através dele se pretendia incorporar as experiências de seis décadas de operações de paz com a finalidade de se produzir direcionamentos, orientações, manuais, materiais de treinamento, padronização de procedimentos para fornecer uma estrutura consistente para o funcionamento do DPKO - Departamento de Operações de Paz das Nações Unidas, uma definição e padronização definitiva para missões, sobretudo de peacekeeping (ONU, 2008). 
Um dos pontos principais é na recuperação dos três princípios básicos do peacekeeping: consentimento, imparcialidade e não-uso da força, salvo sob exceção de mandatos emitidos por conta de auto-defesa. Porém, defende-se o envio de operações mais robustas de peacekeeping em casos de proteção de civis. Também com base nas experiências adquiridas, a doutrina levanta fatores de sucesso que devem ser levados a fundo: legitimidade, credibilidade e local ownership, embora esse último seja o mais desafiador para a organização. Ou seja, o relatório se propõe a oferecer um framework normativo para as próximas missões e foi concebido como parte de reformas no departamento para desenvolver uma doutrina mais clara e padronizada.

Por fim, a geração de peacebuilding, ou a quarta geração de operações de paz, também emerge com base no relatório Agenda for Peace. O peacebuilding era previsto como uma ação para identificar e dar apoio a estruturas que tenderiam a consolidar a paz. A concepção de conflito, nesse caso, seria entendida como aquela baseada em violência estrutural e ressentimento social como as suas principais causas.

Conforme consta no Agenda for Peace, o peacebuilding é entendido como:

The present report in addition will address the critically related concept of postconflict peace-building - action to identify and support structures which will tend to strengthen and solidify peace in order to avoid a relapse into conflict. Preventive diplomacy seeks to resolve disputes before violence breaks out; peacemaking and peace- keeping are required to halt conflicts and preserve peace once it is attained. If successful, they strengthen the opportunity for post-conflict peace-building, which can prevent the recurrence of violence among nations and peoples

\section{(...)}

In the aftermath of international war, post-conflict peace-building may take the form of concrete cooperative projects which link two or more countries in a mutually beneficial undertaking that can not only contribute to economic and social development but also enhance the confidence that is so fundamental to peace. I have in mind, for example, projects that bring States together to develop agriculture, improve transportation or utilize resources such as water or electricity that they need to share, or joint programmes through which barriers between nations are brought down by means of freer travel, cultural exchanges and mutually beneficial youth and educational projects. Reducing hostile perceptions through educational exchanges and curriculum reform may be essential to forestall a re-emergence of cultural and national tensions which could spark renewed hostilities (ONU, 1992, §21; §56) 
O desenvolvimento e as liberdades políticas remediariam a insegurança. Entende-se, portanto, que são premissas amplamente pautadas pela paz liberal, e fruto também do nexo do desenvolvimento com a segurança, que será aprofundado mais adiante no presente trabalho (Sabaratnam, 2011).

Mais tarde, com a publicação do relatório Brahimi, em face das contínuas falhas da instituição, a ONU estabelece bases renovadas para a eficácia das missões de peacebuilding:

Effective peace-building requires active engagement with the local parties, and that engagement should be multidimensional in nature. First, all peace operations should be given the capacity to make a demonstrable difference in the lives of the people in their mission area, relatively early in the life of the mission. The head of mission should have authority to apply a small percentage of mission funds to "quick impact projects" aimed at real improvements in quality of life, to help establish the credibility of a new mission. The resident coordinator/humanitarian coordinator of the pre-existing United Nations country team should serve as chief adviser for such projects in order to ensure efficient spending and to avoid conflict with other development or humanitarian assistance programmes (ONU, 2000, §37)

Para compreender, no entanto, de maneira mais detalhada acerca da emergência dessa concepção de peacebuilding, autores concordam que o fim da Guerra Fria implicou em uma expansão da agenda dos estados membros da ONU: " $a$ near revolution in the relation between what is in legitimate realm of state sovereignty and what is subject to legitimate international intervention (Doyle \& Sambanis, 2006, p. 1)." Foram criadas oportunidades para a "medicação" de locais que teriam sido palcos de conflitos durante a Guerra Fria, ao passo que guerras civis em diversos países se iniciaram como consequência do fim da bipolaridade. Era a erupção de uma nova desordem mundial. Tais guerras civis eram resultado de tensões e rivalidades étnicas, o que autores tais como Duffield (2001) e Kaldor (2001) caracterizaram como "novas guerras". Por um lado, as novas guerras sob o ponto de vista de Duffield (2001) seriam conflitos nãoterritoriais, mas cujos funcionamentos se aproveitariam de complexas redes que funcionam entre e através dos estados.

Seriam marcadas também pela diluição das fronteiras e dos territórios, e pelo caráter de transformação social que promovem através da introdução de novas formas de autoridade e de zonas de regulamentação alternativas. Elas seriam um reflexo da globalização, da integração dos mercados e fluxos locais e 
globais. Sua análise versa sobre a incorporação da emergência de tais conflitos, ao discurso de segurança. A contribuição de seu argumento é em sua discussão sobre o novo nexo entre segurança e desenvolvimento: o subdesenvolvimento, no contexto pós Guerra Fria, é rearticulado de modo a ser entendido como uma ameaça ou perigo a segurança internacional. $O$ projeto de governança lastreado na paz liberal, e expressado através das operações de peacebuilding seriam uma resposta, uma maneira de se levar o desenvolvimento para garantir a segurança, e remediar disfuncionalidades que advêm do Sul e de suas instabilidades.

Kaldor (2001) crê que as novas guerras resultam de um vácuo de poder deixado pela Guerra Fria, mas também no contexto do processo de globalização. Ela alega que refletem um movimento de desintegração do estado, da erosão do monopólio do uso da violência. Elas revelam o declínio da economia em países do sul, o aumento da violência, da queda da legitimidade política.

Com base nesse contexto, o que se constata é que houve um crescimento tanto na demanda quanto na oferta de missões multilaterais para resolução de conflitos durante a década de 1990 (Paris, 2004; Doyle \& Sambanis, 2006; Bellamy \& Williams, 2011). Além disso, mudanças no caráter das operações de paz, observadas ao longo dessa seção, e que se refletem e se cristalizam no peacebuilding, a resposta imediata a tais instabilidades e ameaças. Desse modo, diferente do peacekeeping ou das outras categorias de missões apresentadas acima, ele representa uma tentativa de:

(...) after a peace has been negotiated or imposed, to address the sources of presente hostility and build local capacities for conflict resolution. The aim is to build the social, economic, and political institutions and attitudes that will prevent the inevitable conflicts that every society generates from turning into violent conflicts (Doyle \& Sambanis, 2006, p. 23).

O peacebuilding, portanto, requer a provisão de segurança temporária, a construção de novas instituições capazes de resolver conflitos futuros por meio da paz, economia apta a oferecer empregos aos ex-soldados como civis, e possibilidades de progresso para as gerações futuras (Doyle \& Sambanis, 2006).

Paris (2004) entende peacebuilding como missões que proveriam assistência técnica a atores locais em lugares devastados pela guerra. Essa assistência seria responsável por prevenir a recorrência de violência, e para estabelecer a paz e a estabilidade. Porém, tal assistência não se resume apenas a 
técnica, por promoverem um modelo de organização política e econômica baseados na democracia liberal de mercado. Por uma definição mais completa e normativa, ele sugere também uma fórmula para o modelo:

The typical formula for peacebuilding included promoting peacebuilding included promoting civil and political rights, such as the right to free speech, as well as freedom of association and movement; preparing and administering democratic elections; drafting national constitutions that codified civil and political rights; training or re-training police and justice officials in the appropriate behavior for state functionaries in a liberal democracy; promoting the development of independent "civil society" organizations and the transformation of formerly warring groups into democratic political parties; encouraging the development of free-market economies by eliminating barriers to the free flow of capital and goods within and across a country's borders; and stimulating the growth of private enterprise while reducing the state's role in the economy (Paris, 2004, p. 19).

Enquanto, sob uma perspectiva crítica, Pugh (2009, p. 2), afirma que o peacebuilding envolve uma série de práticas que são intrusivas na sociedade local, que visam assegurar a estabilidade a longo prazo após o final de um conflito.

Embora isso seja contestado, as operações de peacebuilding pós 11 de setembro são caracterizadas por terem, como principal objetivo, a estabilização. Elas representariam uma mudança do foco político - ou, objeto referentecaracterístico das operações anteriores. Seria recuperada a preocupação com a ameaça à segurança nacional em detrimento da segurança do indivíduo. Dessa maneira, o componente humanitário seria secundário e estratégico, e não o objetivo per se. Também é fruto do nexo entre desenvolvimento e segurança, embora o pêndulo se aproxime mais da preocupação sistêmica, ou seja, de se manter a segurança dentre o sistema internacional, o que implica em uma preocupação essencialmente estadocêntrica, em que o objeto referente é o estado nacional. Ao contrário das intervenções humanitárias, por exemplo, a politização é explícita (Muggah, 2010; Barakat et. al, 2010). Elas corresponderiam também a um processo de militarização da assistência humanitária, comumente praticada por atores civis. Para Gordon (2010), as raízes de tais operações estariam nos discursos sobre estados frágeis, que ganharam nova força durante essa era. Elas se pautariam também pela integração entre militar, político e desenvolvimento, e pela busca por promover processos políticos relativamente inclusivos, capacitar o estado para prover o mínimo de segurança necessário, e, por fim, promover melhorias na infraestrutura básica (Gordon, 2010). 
A despeito da visão da OTAN sobre peacebuilding, que operacionalizou missões no Kosovo, Afeganistão, e Iraque, em primeiro lugar, as últimas duas correspondem a missões de estabilização, tal como foi descrito no parágrafo anterior.

A Organização do Tratado do Atlântico Norte (OTAN) foi criada como uma instituição de defesa coletiva e aliança militar, em 1949, a partir do Tratado do Atlântico Norte. Como um fruto das disputas decorrentes da Guerra Fria, a princípio, a função principal da OTAN não era a de conduzir missões de peacebuilding, mas sim, de defesa.

Conforme explicado por Paris e Gheciu (2011, p. 7), tal transformação quanto a função da organização ocorreu com o final da Guerra Fria, em uma fase em que havia uma forte necessidade de se redefinir, pois, sem a disputa, teria perdido a sua relevância e seu propósito. Assim, de acordo com o que já foi exposto aqui, a fase que sucedeu o conflito bipolar foi de intensas mudanças e atividades, de modo que seria uma oportunidade para a OTAN se redesenhar e se readequar ao novo cenário político internacional. Desse modo, os autores apontam que, para tal, a organização deveria então se tornar uma instituição muito mais complexa do que sua ideia original, e teria que ser capaz de cumprir novas funções que deixariam de ser apenas ligadas a defesa de seus membros.

Portanto, com o conflito que eclodiu em Kosovo, a OTAN encontrou uma oportunidade para incorporar uma nova função ao seu escopo institucional, que seria o próprio peacebuilding. No caso de Kosovo, a organização obteve sucesso e pôde alçar reconhecimento como um ator apto a conduzir esse tipo de missão com expertise, de acordo com Paris e Gheciu (2009). Após Kosovo, a OTAN se envolveu nas missões de estabilização no Afeganistão e no Iraque.

Assim, as missões de peacebuilding da OTAN se caracterizariam por aliar métodos de contra insurgência, por se pautar, sobretudo, pelo objetivo de se levar estabilidade. Esses dois elementos se tornaram bastante evidentes nos dois últimos conflitos citados, além de uma forte tendência a militarização da ajuda humanitária. Porém, ainda há preocupação em transmitir valores liberais, principalmente a democracia, que é frequente na retórica dos governantes e líderes por trás dos membros da organização.

Por fim, observamos que as definições de peacebuilding para os autores apresentados apontam para a existência de um projeto político que embasa os 
objetivos, mecanismos, estruturas e práticas de tal categoria de operação. O abandono da neutralidade antes tida como inerente a uma missão de peacekeeping, o final da Guerra Fria e o advento do liberalismo implicaram também em uma mudança política substancial em relação as resoluções de conflitos. O peacebuilding representa a consagração de um modelo de paz liberal que ainda perdura. É a partir dessa visão dominante de resolução de conflito e de operação de paz que emerge uma ampla literatura que se dedica a crítica da Paz Liberal e da sua aplicação. A próxima sessão se debruçará sobre tais críticas, e, finalmente, fornecerá a base teórica para a argumentação a ser desenvolvida.

\section{5 \\ As Críticas à Paz Liberal}

As críticas à paz liberal emergem após as práticas e discursos conduzidos através das operações de peacebuilding, notadamente pelo abandono quase absoluto das três principais características do peacekeeping, consentimento, imparcialidade, e não-uso da força, pelo papel multidimensional e intrusivo, pela implementação de um projeto muitas vezes não condizente com a realidade do local que o está recebendo. Essa noção será amplamente explorada por uma literatura crítica, que foi desenvolvida em vistas de se desconstruir essa receita liberal para a paz, e também a partir da existência de paradoxos entre discurso e aplicação, que são o foco desse estudo.

A crítica a ser adotada no presente trabalho se baseará nos trabalhos de Mark Duffield, Michael Pugh e Oliver Richmond. No entanto, para contextualizar tais críticas, apresentaremos antes as noções de norte e sul globais, que serão repetidamente utilizadas pelos autores referidos, bem como no decorrer do presente trabalho.

\subsection{1}

\section{O Norte e Sul Globais e a Nova Ordem Geopolítica}

Os termos norte e sul globais são oriundos dos estudos da globalização e do pós-colonialismo. Sob o ponto de vista de Mark Duffield (2001, p.3), a 
globalização é um fenômeno que foi responsável por consolidar sistemas econômicos formais e regionais distintos, mas que são integrados e interrelacionados. Tais sistemas são entendidos pelo autor como os centros do funcionamento da economia internacional do ponto de vista formal - ou seja, o norte - que compreende os centros financeiros e comerciais que conjugam redes que estão em contínua expansão. O sul, por sua vez, compreende as regiões que correspondem a áreas que não estão completamente integradas com tais centros. Sua inclusão na economia formal e em tais fluxos financeiros e produtivos se dá de maneira desigual e marginalizada.

David Slater (2004) insere a discussão sobre norte e sul em meio ao contexto de final da guerra fria. Entre 1989 e 1992, ficou evidente que a lacuna entre primeiro e terceiro mundos apenas cresceria, o que suscitaria uma série de debates e questionamentos. $\mathrm{O}$ autor também concorda que tal nova ordem geopolítica mundial seria decorrente da aceleração da globalização e da explosão do número de conflitos sociais. É uma continuidade às narrativas de marginalização, pobreza e exclusão, que substitui o termo terceiro mundo, característico da guerra fria.

Christine Sylvester (2011, p. 192), também sob um viés pós-colonial, entende o sul global como "in various forms within and across former colonial powers, as well as in former colonies associated with the southern hemisphere". O fluxo agora s associatedmigração ocorre do sul para o norte, das colônias para os poderes. Ela também aborda a emergência de tal ordem geopolítica durante o início da década de 1990.

Para a autora, para compreender as relações políticas entre norte e sul globais, é necessário retomar as origens do terceiro-mundismo, na conferência de Bandung, em 1955, que ocorreu como reflexo dos processos de descolonização que estavam em curso durante essa mesma década. Na medida em que a guerra fria terminou, tal terminologia perdeu força, e a nova configuração do poder global exigia também uma nova maneira de se compreender tal ordem. Foi desse modo então que as denominações, referentes aos dois polos, teria emergido. Embora não corresponda necessariamente a ideia territorial que transmite, uma vez que existem países subdesenvolvidos no norte, e vice-versa.

Os autores a serem discutidos a seguir se apropriam de tal contexto e concepção de norte e sul globais para se aprofundarem em suas discussões acerca 
de segurança, e, sobretudo, como as agendas de peacebuilding e nexo entre segurança e desenvolvimento se pautaram por tais mudanças na ordem geopolítica global.

\section{5 .2}

\section{Mark Duffield: Segurança, Subdesenvolvimento e Shadow Economies}

A crítica de Duffield (2001) se centra sobre elementos relacionados ao bem-estar, que se traduz na emergência das economias de sombra, em elementos relacionados à implementação de uma economia de mercado e suas consequências inesperadas (em forma de economias de sombra), e de governança, tanto em relação a implementação de instituições no âmbito doméstico quanto na estrutura de poder representada pelas instituições internacionais, se observarmos sob o prisma de quais características do liberalismo ele se volta.

Em primeiro lugar, a obra do autor referido (Duffield, 2001), Global Governance: The Merging of Development and Security, erige sua crítica a partir da reflexão sobre a emergência do nexo entre segurança e desenvolvimento a partir das novas guerras e de sua visão mainstream, características do final da Guerra Fria. Duffield (2001) fundamenta sua argumentação a partir da existência da noção de que a instabilidade e o subdesenvolvimento do Sul global geram conflitos e potenciais ameaças à segurança internacional. Instabilidades que incluem, para além da erupção de conflitos civis, atividades criminosas e ilegais, tais como o tráfico de drogas e o terrorismo - que operam através de uma grande rede que perpassa pela legalidade do Estado. Ou seja, é a securitização do subdesenvolvimento, em que o objeto referente em questão é o norte.

Questiona-se qual a efetividade de um modelo de desenvolvimento baseado na paz liberal, vis-à-vis a emergência de complexas redes de economias não formais nos países do sul. O autor joga luz sobre as relações de poder presentes nas economias das "sombras" e permite uma melhor compreensão acerca dos desdobramentos da aplicação do modelo liberal, porém atentando para as dinâmicas presentes nas margens e suas complexidades. 
Com esse pano de fundo, o autor sugere que há uma nova lógica por trás do capitalismo que se baseia em um processo de exclusão do sul. Assim, as novas relações sociais que acontecem através de interconexões, interações e interdependência são pautadas pela subordinação do Sul pelo Norte. O Sul busca se reintegrar no sistema, mas, por não ter recursos ou pela falta de sucesso das tentativas de implementação de reformas neoliberais, o faz através de atividades transfronteiriças paralelas, ou as shadow economies, que são caracterizadas pela não-formalidade.

As shadow economies, como fenômeno e como conceito que será utilizado ao longo desse trabalho, não só funcionam na ilegalidade, como também penetram o legal e o lícito. Estão presentes nos meandros dos sistemas formais e muitas vezes, dependem de tais estruturas para funcionarem. Tais economias funcionam em redes transnacionais através de complexas estruturas de poder. São dinâmicas, flexíveis, se adaptam rapidamente a mudanças. Existe, assim, uma profunda articulação entre a economia formal e a não formal. Essas atividades se traduzem também em uma grande mudança na natureza das relações de poder e de autoridade, e que não refletem as concepções tradicionais de soberania. Dentro das shadow economies, podemos incluir as drogas, o contrabando, e falsificações. Porém, as drogas como economia informal será explorada mais adiante nos capítulos finais (Nordstrom, 2004; Duffield, 2001).

Duffield (2001) também aponta para uma tendência de criminalização de determinados conflitos, sob a ótica da paz liberal. Durante a década de 1990, eram comuns descrições de grupos violentos e anárquicos, e sem programas políticos. As descrições mais recentes, contudo, apontam para uma tendência que incorporam determinados elementos da literatura disponível sobre war economies para explicar a emergência de sistemas cuja violência é sustentada pelo crime (Duffield, 2001, p. 130).

Para a governança global, a intensa atividade criminal, presente nos países do Sul e através de tais economias de "sombra", resulta em colapsos sociais, pobreza, traumas e erosões na coesão social. As operações de state-building e as ajudas humanitárias refletem, portanto, tais novos objetivos da paz liberal, que articulam desenvolvimento e segurança. Dessa maneira, reconstruir um país sob esse molde seria um modo de se evitar novos conflitos. 


\subsection{3}

\section{Michael Pugh: Peacebuilding e Bem-estar}

Já Michael Pugh (2004), faz suas críticas à luz da teoria crítica e se centra, sobretudo, na centralidade do indivíduo, em suas liberdades, e em seu bem-estar. Em seu texto "Peacekeeping and Critical Theory", ele se debruça especificamente sobre as operações de paz, e argumenta haver um caráter imperialista por trás de tais missões, e pergunta de que maneira sustentam determinadas representações de normas da governança global. Ele se apropria tanto de Duffield, já discutido nessa sessão, quanto de Robert Cox, expoente da teoria crítica nas Relações Internacionais. Segundo Pugh (2004), outro problema surge na literatura, como reflexo desse fenômeno. As interpretações que são feitas sobre a paz liberal e as operações de paz não questionam a ordem, que é tida como realidade. Ele defende uma abordagem que exponha as injustiças que emergem das ideologias - sejam elas liberais ou realistas, - que são aceitas como verdades absolutas. O autor acredita na necessidade de se analisar o potencial para transformação nas estruturas existentes e também no potencial para a emancipação.

Quanto a sua concepção sobre a paz liberal, Pugh (2005, p. 24) atenta para um de seus principais aspectos: “A key aspect of the 'liberal peace' thus promotes a form of economic control and regulation to establish market correctives in societies that have been resistant to conventional marketisation imperatives." Assim, as definições tanto de Duffield quanto de Pugh apontam para um caráter de controle na paz liberal, que aparece em diversos âmbitos (população e econômico).

Além disso, no capítulo publicado chamado "Towards life welfare", o autor, ainda incorporando alguns conceitos desenvolvidos por Duffield, no caso, das economias informais, agrega à tal concepção a sua própria discussão relacionada ao bem-estar, que merece atenção para essa pesquisa, como uma das características chave do liberalismo tradicional. No parágrafo transcrito abaixo, ele discute a importância do bem-estar para o peacebuilding, e propõe que o modo pelo qual o bem-estar é abordado nesses processos não tem obtido sucesso, gerando consequências tal como oportunidade para desenvolvimento de tais economias. 
In both the academic conceptualization and the discursive practices of liberal peacebuilding, much attention is focused on institutions and capacities for democratization, rule of law and institution-building at the levels of the state and semi-autonomous authorities such as provincial governments. A paradigm shift would require attention to two other analytical spheres that tend to be either neglected or divorced from each other in literature: the welfare of everyday life and the conditionalities of global capitalism. A shift would thus operate at two levels: continuous and equitable engagement with the diverse local cultural and welfare dynamics on the one hand, and restructuring and disempowerment of the existing financial hegemony at a global level (Pugh, 2009, p. 79).

As agências de peacebuilding creem em prover o bem-estar através da priorização da ajuda humanitária e de sistemas de redes de segurança. Tais funções são normalmente incumbidas as ONGs, suplementando as responsabilidades do estado (Pugh, 2009).

Pugh também acrescenta ao argumento de Duffield que as economias informais representam uma busca real pelo bem estar: o peacebuilding liberal acaba marginalizando definições e possibilidades locais tanto para a paz, quanto para o bem-estar, e enquanto os indivíduos recorrem as economias informais, os agentes interventores as consideram ilegítimas (Pugh, 2005). Ele entende que o bem-estar cumpre um papel crítico na busca pela paz positiva. Porém, deve se enraizar nas sociedades locais. O bem-estar seria essencial para assegurar diversos elementos essenciais para a manutenção da paz, desde identidade, coesão social, e legitimação de contratos sociais.

Uma das principais críticas de Pugh (2009) se erige a partir do fato de que existe um paradigma por detrás da economia política que crê que sistemas e comportamentos econômicos podem ser modificados por agentes externos, objetivando a implementação de um modelo de desenvolvimento particular - que é o que ocorre no peacebuilding pelo projeto da paz liberal. O bem-estar, desse modo, é promovido através do aumento da capacidade de consumo, e não conforme ele sugere, tal como exposto no parágrafo anterior. Os modos utilizados pelos agentes emergem de discursos que representam interesses específicos do capitalismo, como se fossem a única e última opção disponível. O autor cita ainda Murphy e Cox (Pugh, 2005, p. 38) demonstrando como a desigualdade política deixa muitos sem controle de suas próprias vidas, ou como também provoca um processo de despolitização.

As Murphy (2005: 18) notes, political inequality leaves many with no control over the major decisions that affect their lives. For Cox, too, "whereas the right of 
self-assertion is celebrated, in a social and economic context the individual's capacity to exert control over the systemic factors that determine its implementation is removed. Consequently, just as in one-party, authoritarian regimes, politics is about depoliticizing people, by removing the economic determinants of everyday conditions from political control" (Cox, 1992).

O que ele procura provar é que: "The contention here is that uninsured populations, to use Mark Duffield's term, often do tolerate robber barons, because interventionist economic policies make life unpleasant (Pugh, 2009, p. 79)". Ou seja, as economias informais são a maneira pelo qual se tenta atingir o bem-estar, dado que o modelo da paz liberal não permitiu que isso ocorresse com plenitude. A política econômica da paz liberal subjuga, exclui, marginaliza e não permite emancipação. Os problemas socioeconômicos presentes nas sociedades que estão sofrendo intervenção são relegados às margens dos projetos, quase sempre mal implementados. Ocasionam, além de tudo, em reforçar as diferenças e vulnerabilidades, e "does little either to alleviate people's engagement in shadow economies or to give them a say in economic reconstruction (Pugh, 2005, p. 25)"

\section{5 .4}

\section{Oliver Richmond e a Valorização do Indivíduo Local}

Por fim, acrescenta-se a crítica de Oliver Richmond (2005), que centra seu trabalho sobre aspectos relacionados a centralidade do indivíduo, as instituições tanto no âmbito doméstico quanto internacional, e na participação política local , além de jogar luz sobre o caráter hegemônico do projeto da paz liberal. A política de exportação da democracia como padrão para evitar conflitos foi universalizada, como estratégia para colocar um fim às guerras. Os conflitos, dentro desse contexto, seriam tidos como disfuncionais, e que poderiam ser modificados por meio da adoção de abordagens mobilizadas como corretas, sejam elas sociais, políticas ou econômicas. Porém, tal estratégia é posta em prática através da hegemonia dos estados mais poderosos, e se solidifica como uma forma de governança global.

Richmond (2011) também critica o fato de que a paz liberal não é um projeto emancipatório, ao contrário, se fundamenta pela governamentalidade, ou seja, pela capacidade de controle das sociedades nas quais se intervém. Tal projeto 
acaba engendrando e reforçando o etnocentrismo, o enviesamento cultural, e reflete um conjunto muito estreito de interesses, pautados pelo neoliberalismo. A exportação e implementação de um modelo ocidental supõem a noção de um modelo sobre outro, que adquire tom de superioridade, quase imperialista. Pois emana das experiências ocidentais de desenvolvimento, de sociedade, soberania, de instituições e do próprio estado westfaliano.

A crítica construída por Richmond (2005) também atenta para o fato de que muitas das instituições componentes do projeto da paz liberal, ou seja, da governança global, embora promovam a democracia, não são democráticos em seus próprios funcionamentos, de modo que perpetuam as hegemonias, cristalizam estruturas de poder e não abrem qualquer possibilidade para emancipação.

Porém, em obras mais recentes, o autor (Richmond, 2011) também propõe criticar o que ele considera uma das maiores falhas do projeto liberal, que seria o engajamento e envolvimento direto com os atores locais, e um profundo entendimento de outros sistemas e complexidades existentes no local que sofrerá intervenção e operação de peacebuilding.

A falta de tal comprometimento implica em muita insatisfação. As relações entre interventores e locais são como de gerente e seus sujeitos, e a paz liberal ganha corpo como um contrato entre tais instâncias, ao invés de ser um produto local.

Além disso, política no processo de peacebuilding começa sempre a partir da preocupação com a segurança e com a construção de instituições, enquanto deveria favorecer, em primeiro lugar, o desenvolvimento da justiça social, da comunidade, e da vida cotidiana.

Ou seja, o que nos importa é como que, na prática, a paz liberal prioriza a segurança, a estabilidade, a erradicação do terrorismo, e como os direitos humanos, a vida cotidiana, os atores locais, a justiça social são relegados às margens. Embora conforme citado por Richmond (2011), a grande aspiração do liberalismo como ideologia seja o indivíduo e suas liberdades. O que ocorre é que a paz liberal é estruturada pela noção de estado soberano e, principalmente, pelo mercado e seus interesses, representados no modo pelo qual os grandes doadores, governos, organizações internacionais e ONGs produzem os sujeitos nesse contexto. A paz se torna, em última instância, um conjunto de instituições que 
compõe uma governança global. Não é uma "everyday peace", mas administra-se a vida através de controle e governamentalidade, para manutenção da ordem e da estabilidade global, tentando conter a violência e recorrência de conflitos. É o que podemos entender como segurança em seu sentido liberal, conforme será discutido na próxima sessão. 


\section{2 \\ As Diferentes Concepções de Segurança}

O presente capítulo pretende explorar quais os conceitos e definiçõos de segurança existentes nas teorias das Relações Internacionais, para, em seguida, pensar, dentro da hipótese do trabalho, qual é a concepção de segurança e objeto referente por trás dos projetos de peacebuilding.

$\mathrm{O}$ argumento do trabalho se baseará na existência de diferentes concepções de segurança, ou seja, entre concepções de segurança cujo foco, ou objeto referente, é o estado ou o indivíduo, atreladas às operações de paz, e que refletem as mudanças no cenário político e implicam também em mudanças normativas. Isso sustentará a noção do porquê as drogas foram marginalizadas no Afeganistão. No estudo de caso sobre o Afeganistão, que será apresentado no último capítulo, se classificarmos a operação da OTAN de estabilização no país, e, conforme será explicado, como sistêmica, ou seja, entende-se que a concepção de segurança que a pauta corresponde à restrição da existência de ameaças apenas às soberanias estatais, ou seja, às seguranças nacionais. Ou, conforme autores como Richmond (2011, p. 8) que crê que: “This is because the liberal peace's primary goal in its intervention into the local is actually aimed at stability in international order between sovereign states".

Essa concepção de segurança internacional deriva do pensamento realista, que se manteve hegemônico durante décadas de pensamento político internacional (Buzan \& Hansen, 2012).

Porém, a partir da década de 1990, o indivíduo se tornou o grande foco, ou, no caso da unidade analítica a ser utilizada aqui, objeto referente, a quem a segurança deveria ser garantida, e quem a comunidade internacional deveria se preocupar em proteger (MacFarlane \& Khong, 2006). Essa mudança pautou as intervenções humanitárias e outras missões ao longo dessa década, sob a bandeira 
da paz liberal. Isso se traduziu também em mudanças na academia e nas agendas de pesquisa.

A evolução dos estudos de segurança, e sua consolidação como uma subárea da disciplina das Relações Internacionais, ainda é recente. O conceito em si ainda é discutido, desafiado e contestado entre os acadêmicos, principalmente por suas origens normativas enraizadas nas tradições realistas.

Assim, o presente capítulo pretende, em primeiro lugar, fornecer a definição conceitual para o objeto de referência como unidade analítica que será utilizada ao decorrer do trabalho, apresentar as bases das concepções tradicionais de segurança, seus principais conceitos, agenda de pesquisa e objeto referente. Em seguida, serão discutidos os processos de ampliação e aprofundamento do conceito, quais as implicações de tais processos e respectivos objetos referentes.

\section{1}

\section{O Objeto de Referência}

O conceito de objeto de referência, como unidade analítica, que será utilizado aqui, foi formulado pela Escola de Copenhague (que, por sua vez, será tratada com maior detalhes nas próximas sessões), e ampliado por autores das escolas críticas. O que nos importa aqui é o conceito em si, que nos servirá como metodologia de análise para compreender para quem é a paz liberal, e, na prática, a missão da OTAN no Afeganistão.

Embora o conceito faça parte de uma ideia de processo, em primeiro lugar, o objeto referente é algo que esteja sendo ameaçado existencialmente, nas palavras de Buzan et al (1998, p. 36). Assim, é algo que precisa ser protegido: "Security action is usually taken on behalf of, and with reference to, a collectivity. The referent object is that to which one can point and say, 'It has to survive, therefore it is necessary to...' (Buzan et al, 1998, p. 36).

Enquanto parte de um processo de um processo, um objeto referente é normalmente definido por um ator securitizante, e através de um ato de fala. Alguém deve determinar, discursivamente, que o objeto referente em questão está sendo ameaçado. A ameaça em si também deve ser definida por esse mesmo ator. 
Nas Relações Internacionais, conforme colocado pelos autores da escola de Copenhagen, as escolas tradicionais tinham (ainda têm), como objeto referente, o estado.

Porém, a proposta da escola é justamente de que se abra tal possibilidade, e de que outras coisas, sobretudo grupos e coletividades, possam ser tidas como objetos referentes também. Desse modo, para esse trabalho, tampouco nos limitaremos ao estado como único objeto referente, e, para tanto, diferenciaremos as concepções de segurança tradicionais, e os subsequentes processos de ampliação e alargamento, que foram responsáveis por permitir com que a agenda de segurança estudasse questões para além do estado-centrismo e de um sistema baseado nessa exclusividade de atores.

Como tais objetos são definidos sobretudo através de discursos, praticamente qualquer coisa pode ser definida como ameaça e qualquer coisa como objeto referente - normalmente isso corresponde a alguma ideia de coletividade (Buzan et al, 1998).

Assim, quando determinada questão é apresentada, discursivamente, como uma ameaça existencial para um público, isso justifica o uso de qualquer medida, sejam elas extraordinárias ou não, para fins de sobrevivência e proteção (Buzan et al, 1998, p. 21).

Para fins da presente pesquisa, nos utilizaremos desse conceito, no entanto, sob o viés mais crítico, principalmente tal como proposto por Krause e Williams (1997), ou, ainda, conforme abordado pelas concepções de segurança humana, em que o indivíduo pode ser considerado um objeto referente. A evolução conceitual entre Escola de Copenhague e as motivações que levaram ao aprofundamento por autores como Krause e Williams (1997) e Booth (2005), bem como a emergência do conceito de segurança humana, serão desdobradas nas sessões a seguir, e fornecerão também a contextualização completa para compreender de modo profundo a origem da noção de objeto referente. 


\section{2}

\section{Concepção Tradicional de Segurança}

Os estudos de segurança surgem em virtude das guerras e da preocupação em evita-las, em proteger os estados de uma possível recorrência de conflitos tão desastrosos. Sua guinada foi a partir da Segunda Guerra Mundial, embora as primeiras publicações das Relações Internacionais, como disciplina, tenham sido do período entre guerras (Buzan \& Hansen, 2012). Dessa maneira, a própria disciplina das Relações Internacionais já nasce indissociável dos estudos de segurança, por emergir do interesse de se entender tais conflitos (Booth, 2005).

Emergem, também, como uma maneira de se diferenciar de outros campos de estudo: da história militar e dos estudos estratégicos (ou de guerra). Os que são atualmente chamados estudos estratégicos correspondem a literatura clássica representada por autores como Clausewitz, e outros expoentes da geopolítica, como Mahan. Os estudos de segurança, por sua vez, consolidaram-se, mais tarde, como subárea das Relações Internacionais enquanto disciplina, embora tenham se originado independentemente.

Foi gerada uma literatura específica e distinta do que era produzido nos anos anteriores a Segunda Guerra Mundial (Buzan \& Hansen, 2012). Buzan \& Hansen (2012), em sua obra de destaque A Evolução dos Estudos de Segurança Internacional, enfatizam a importância adquirida pela subárea dentro do ocidente, onde a presença é constante e de grande relevância nas universidades.

Assim, o conceito de segurança já nasce vinculado às noções de guerra e de Estado-nação, equipado com uma agenda de pesquisa estritamente militar, respondendo a antigas demandas políticas que correspondiam a determinado contexto histórico-, ou seja, o final da Segunda Guerra Mundial e o início da Guerra Fria. A Guerra Fria já se inicia, estabelecendo como um de seus pressupostos, a existência de armas nucleares.

Para Buzan et. al (1998, p. 21), deve ser feita a distinção do conceito de segurança para as relações internacionais, pois é diferente de seu uso corrente no dia a dia. Segurança, como subárea, teria seu próprio significado, enraizada nas tradições da power politics. Por fazer parte de uma tradição militar e política, aqui, segurança necessariamente estaria ligada com a noção de sobrevivência:

It is when an issue is presented as posing an existential threat to a designated referent object (traditionally, but not necessarily, the state, incorporating 
government, territory and society). The special nature of security threats justifies the use of extraordinary measures to handle them. The invocation of security has been the key to legitimizing the use of force, but more generally, it has opened the way for the state to mobilize, or to take special powers, to handle existential threats. Traditionally, by saying "security", a state representative declares an emergency condition, thus claiming a right to use whatever means are necessary to block a threatening development (Waever 1988, 1995b).

Ou seja, não apenas segurança é uma questão de sobrevivência, quanto também engloba a reação a uma ameaça, e a justificativa para o uso de medidas extraordinárias para esse fim. É declarar uma situação de emergência, invocar o conceito de segurança, e adotar e mobilizar medidas, ou ampliar poder para garantir a sobrevivência de quem estiver ameaçado.

Os estudos de segurança estariam estruturados em torno de quatro questões chaves, conforme estabelecidos por Buzan e Hansen (2012), que foram o cerne dos debates do nascimento da subárea. Seriam conceitos que teriam servido como lentes analíticas, e que também poderiam ser considerados como conceitos substanciais da subárea, responsáveis por definir e constituir os estudos de segurança internacional.

A primeira questão diz respeito ao lugar do Estado como objeto de referência. A concepção de Segurança enquanto entendida pelos tradicionalistas diz respeito à constituição de algo que precisa de segurança, que precisa de proteção com relação a alguma ameaça. Nesse caso, sobretudo no caso tradicionalista, tal objeto seria essencial e exclusivamente o Estado. É portanto, um pressuposto normativo, que exclui qualquer outra possibilidade de objeto que pode estar suscetível a alguma ameaça. A extensão desse debate será primordial no entendimento da evolução dos estudos de segurança.

A segunda questão se centra sobre a possibilidade de se incluir ou não ameaças tanto internas quanto externas, dado que uma das bases da concepção de Segurança seria a soberania do Estado nacional. Ela diz respeito à sobre como posicionar as ameaças em relação ao território, de modo que está ligada a discussão entre segurança nacional e segurança internacional, e quais os limites entre esses dois conceitos.

'National security' should thus, as many observers have pointed out, more appropriately have been labelled 'state security', yet, what the Cold War concept of 'national security' entailed was more accurately a fusion of the security of the state and the security of the nation: the nation supported a powerful state which in 
turn reciprocated by loyally protecting its society's values and interests (Buzan \& Hansen, 2009, p.11).

A terceira questão é o próprio dilema em relação a expansão da subárea de modo que inclua outras ameaças que não apenas as militares, o que será discutido mais a fundo nas próximas sessões. Por fim, a última questão levantada pelos autores é se devemos enxergar a concepção de segurança como indissociável das noções de ameaças, perigos e da urgência. Assim, essas quatro questões poderão ajudar a nortear uma discussão para compreender os estudos de segurança e sua subsequente evolução e expansão após a Guerra Fria.

Além dessa maneira de se estruturar e propor um estudo sistemático da subárea, Buzan e Hansen (2012) propuseram também entender o conceito de segurança através de outros conceitos adjacentes, ou conceitos chaves. Eles sugerem tal discussão detalhada por acreditarem que o conceito em si ainda é pouco desenvolvido academicamente, de modo que sua obra se preocupa em alimentar esse debate e fornecer possíveis refinamentos teóricos. A literatura, anteriormente, se referia mais a estudos da paz do que da segurança, ou aos estudos estratégicos, que historicamente antecederam os estudos de segurança. Serão tratados com maior detalhe na próxima subseção.

\subsection{1}

\section{As Tradições Realistas}

$\mathrm{O}$ que hoje se entende por estudos da segurança nas Relações Internacionais, para Buzan e Hansen (2012), nascem dos estudos estratégicos e históricos, que prevaleceram até os anos de 1940. Os trabalhos que foram produzidos durante essa década e a década de 1950 apontavam para uma interseção entre diferentes áreas, por exemplo, estudos militares, Ciências Sociais, Ciência Política. Tais estudos já se debruçavam sobre a recém iniciada Guerra Fria, procuravam entender os problemas políticos que emergiam com a existência das armas nucleares e a bipolaridade. Porém, o que a subárea inaugurou foi a possibilidade de se estudar guerra e assuntos militares por civis:

Because of their crucial contributions during the Second World War, civilian experts, mainly physicists and social scientists, could now specialise in military issues under the heading of security, which unlike 'war' or 'defence' nicely 
bridged the military and non-military aspects of the subject. (Buzan \& Hansen, ver de que ano é versão em inglês, data)

Durante toda a Guerra Fria, pensar em segurança esteve indissociavelmente ligado à hegemonia do pensamento realista. Buzan em People, States and Fear (1983) aponta que as abordagens tradicionais que se baseiam na noção de poder estão enraizadas em tal tradição, sobretudo nos autores considerados pioneiros dessa escola, a saber: E. H. Carr e Hans Morgenthau. Nesses autores, se encontra o argumento de que o poder é a principal motivação por trás do comportamento dos atores no sistema internacional. A busca pelo poder seria tida como característica da natureza humana, de modo que estados estariam sempre buscando aumentar suas capacidades, em um ambiente anárquico, livre de um governo ou de uma hierarquia para regê-los. A obra mais emblemática do chamado realismo clássico seria "Política entre as nações", de Morgenthau, em que ele explora e sistematiza tais pressupostos. Nesse sentido, a obra de Waltz (1979) surge como uma antecessora a tradição clássica, inaugurando o neorrealismo que acrescenta o componente estrutural à teoria.

Em sua teoria, prevalecia a ideia de que o Estado deveria preocupar-se com sua sobrevivência, em face de um sistema internacional anárquico (Waltz, 1979). Ou seja, a sobrevivência de um Estado era equivalente a segurança nacional, ideia tida como dada pelos neorrealistas, na qual se acredita que os governos nacionais devem ter legitimidade para garantir a segurança de sua população e território.

A busca pela sobrevivência seria inquestionável, e o Estado poderia ou não usar a força para esses fins. Waltz (1979) a entendia como uma de suas premissas basilares. Sua análise pressupõe também que, entre os estados, por estarem ordenados anarquicamente, encontram-se em estado equivalente ao de natureza, e, assim, sempre existe o risco de uma guerra acontecer. Waltz (1979) explica também que o sistema internacional se baseia na autoajuda, pois os estados não podem depender de outros para sua proteção. Devem, portanto, buscar meios para que possam se defender sozinhos. Assim, é a anarquia que conduz e molda o comportamento dos atores, e o uso da força é uma possibilidade real:

The state among states, it is often said, conducts its affairs in the brooding shadow of violence. Because some states may at any time use force, all states 
must be prepared to do so-or live at the mercy of their militarily more vigorous neighbors. Among states, the state of nature is a state of war. This is meant not in the sense that war occurs but in the sense that, with each state deciding for itself whether or not to use force, war may at any time break out (Waltz, 1979, p, 102).

Segundo Baldwin (1997), nenhuma teoria de Relações Internacionais propriamente dita enfatiza tanto a questão da Segurança quanto o neorrealismo. Conforme demonstrado através das transcrições de Waltz (1979), e segundo também apontado por Baldwin (1997), pode-se notar que a segurança é, de fato, a principal motivação dos estados em meio a um ambiente anárquico. Pois é apenas se os atores conseguem sobreviver, que podem buscar outros objetivos (Waltz, 1979). Baldwin (1997), no entanto, crê que tais constatações de Waltz (1979) sejam muito simplistas e não levem em conta, por exemplo, os riscos e custos de tais motivações para os atores.

Um dos conceitos-chave para a compreensão da noção tradicional de segurança é o dilema da segurança, abordado exaustivamente por uma série de autores. Conforme colocado por Schweller (1996), o que neorrealistas entendem pelo conceito é: sempre existe a possibilidade do uso da força em um sistema anárquico, e, com base nisso, o dilema da segurança é que o aumento na segurança de um Estado diminui a segurança dos outros. Schweller (1996) observa também que, para Waltz, o dilema é uma constante entre os atores, de modo que é uma condição, visto que não se sabe quais as intenções do outro, então tendem a se armar para se proteger em face da dúvida e incerteza em relação ao outro. Mesmo estados pacíficos participam de tal configuração. O conceito, para as Relações Internacionais, se sustenta na ideia de que sempre existe a chance de que o outro possa ser agressivo, então, em um contexto de atores auto interessados cujos comportamentos se baseiam na autoajuda, é natural que isso ocorra.

Assim, o cerne do realismo se baseia na ideia de segurança; seja em busca pelo poder ou pela sobrevivência, a anarquia do sistema internacional torna o ambiente inseguro, incerto, e tanto uma busca quanto a outra, visa, no fundo, a segurança do ator. Pois, por exemplo, ter mais poder implicaria em ter mais capacidades e ser capaz de prover maior segurança e proteção ao seu território e aos seus indivíduos. 
Pela teoria realista ser essencialmente parcimoniosa, objetiva, e buscar proximidade ao positivismo, ela toma como pressupostos determinados conceitos, atores e elementos que estreitam sua agenda de pesquisa e não permitem olhares sobre outras dinâmicas de poder que permeiam apenas a relação entre estados e a ameaça constante do uso da força. Isso permitirá com que outros teóricos percebam essa lacuna do realismo, e proponham novos caminhos para a subárea da segurança.

Por fim, tal noção baseada em um sistema de estados, na qual a segurança é ligada à ideia de segurança nacional, e que os estados estão configurados e pautam suas ações baseadas nela, o que podemos compreender é que o objeto referente, sobretudo do realismo, é o próprio estado. Ou, segundo resumem Buzan et al, 1998, p. 36: “The referent object for security has traditionally been the state and, in a more hidden way, the nation. For a state, survival is about sovereignty (...)." Dado que tomam como pressuposto a política interna, excluem a possibilidade de se abordar o indivíduo no âmbito internacional.

\subsection{2}

\section{A Tradição Liberal}

Pensar sobre segurança sob a luz do liberalismo também nos leva diretamente a Kant. A abordagem liberal em relação à segurança está associada a paz. Ou seja, diferente do realismo,

Those who favour the approach through peace are more loosely associated into the idealist school. They can argue that their concept leads them not only to see the problem in holistic terms, as opposed to the necessarily fragmented view of the Realists, but also that it focuses attention directly on the essential matter of war. Since war is the major threat arising from the national security problem, a solution to it would largely eliminate the problem from the international agenda. (Buzan, 1983, p. 2)

Foi o pensamento de Kant que inaugurou o que hoje se entende por paz democrática. Kant (2004), em sua obra “A Paz Perpétua”, acreditava no progresso moral dos seres humanos, e que almeja-se, em última instância, uma paz perpétua entre as nações, que, embora seja impossível, devemos tentar nos aproximar dela o quanto for possível ao longo da História. A paz perpétua seria, sobretudo, produzida por estados republicanos, de modo que Kant (2004) acreditava que 
apenas eles, por já estarem em um estágio de progresso moral, de certa maneira, a frente, adotavam comportamentos pacíficos. Pois a ideia de república, para ele, era no sentido de consulta aos cidadãos, que poderiam rejeitar ou aceitar uma guerra, por exemplo. As repúblicas e suas formas institucionais também seguiriam esse caminho do progresso moral, de modo que haveria diálogo tão intenso entre soberano e sujeitos, que o soberano saberia, com o tempo, traduzir e oferecer adequadamente as demandas dos cidadãos. Assim, Kant (2004) entendia que esse diálogo também poderia ser desenvolvido entre as repúblicas, que poderia ultrapassar as fronteiras domésticas, embora não houvesse um soberano internacional propriamente dito.

Para além de Kant, a trajetória do liberalismo como um conjunto de ideias, valores e instituições, ou seja, centralidade do indivíduo, seu bem-estar, liberdade e participação política, representação democrática, livre comércio, economia de mercado e crença nas instituições, também constituiu o que pode ser entendido como um ponto de vista da segurança. Em diferentes medidas, as relações entre as nações não necessariamente buscam a sobrevivência ou o poder. Uma das constantes entre os teóricos ditos liberais das Relações Internacionais é a ideia de cooperação, que se alia com a noção de paz democrática- a última, como também já foi discutido, amplamente lastreada em Kant. A cooperação pode ocorrer através do comércio, ou, principalmente, através de instituições. Existe a crença de que instituições, no caso, internacionais, que, ao convergir os interesses dos atores e diminuir os custos de transação entre suas relações diminuem as chances de conflito.

Embora já tenha sido discutido no capítulo anterior, através da literatura de Michael Doyle (2012), a paz democrática também pode ser entendida como uma visão de segurança específica do liberalismo: em parte porque o argumento central seria justamente que estados liberais não entrariam em guerra com outros estados liberais. Porém, existiria a chance de se entrar em guerra com estados não liberais - e promover a democracia para além da "comunidade liberal" poderia ser um motivo para tal. Estados liberais seriam, portanto, mais pacíficos se comparados com outros estados, de modo que "espalhar" a democracia consequentemente traria mais paz ao mundo:

Liberal states are different. They are indeed peaceful - among themselves. But they are also prone to make war - against nonliberal states. Modern liberalism 
carries with it two legacies, peace and war. They affect liberal states, not separately, but simultaneously (Doyle, 2012, p. 2).

A presença de tais elementos na retórica de líderes, sobretudo dos Estados Unidos, foi frequente, e os discursos comumente se referiam a uma vontade de se levar a democracia para libertar as pessoas que viviam sob outros regimes. Alguns líderes referiam a isso como uma cruzada pela liberdade, ou como um alargamento da democracia. O que Doyle (2012) aponta também é que isso não é recente: já havia sido inaugurado por Woodrow Wilson.

Outro autor expoente acerca da paz democrática e paz liberal, Bruce Russett (1993), conduziu uma pesquisa quantitativa para confirmar a teoria da paz democrática, de que países liberais não entram em conflito entre si. Pois, em primeiro lugar, teriam outros modos para resolver seus conflitos, principalmente através da própria democracia, e portanto, não precisam fazer uso da violência. No entanto, isso não significa que não entrem em conflito com outros sistemas políticos. Pelo contrário, se houver necessidade, sobretudo para promover a paz liberal e seu conjunto de valores liberais: liberdade do indivíduo, bem-estar, direitos individuais, participação política, representação democrática, livre comércio, livre mercado, e crença nas instituições, sendo as últimas construídas para garantir todos os primeiros valores citados.

A paz liberal no sentido de um projeto político, enraizado na tradição liberal, que também foi discutido no capítulo anterior, prega que instituições liberais sólidas, aliadas ao desenvolvimento, trariam segurança. Promover o supracitado conjunto de valores liberais, levar a democracia para outros estados, melhorar a governança e levar o desenvolvimento seria benéfico, no sentido da segurança, para os países do norte (Duffield, 2001). Há um certo radicalismo nesse processo, face a locais que estão, na realidade, excluídos do sistema capitalista. Existe uma relação clara de poder, em que tais países estão subordinados às vontades e a esse projeto liberal. $\mathrm{O}$ radicalismo está no fato de que o projeto em si pretende transformar essas sociedades, que, por estarem permeando por fora do liberalismo formal, são tidas como disfuncionais e ameaçam a segurança e estabilidade do Norte (Duffield, 2001). Ou seja, o liberalismo deve também ser preservado para além de sua expansão. Assim, nesse sentido, para Duffield (2001), o objeto referente seriam os estados do norte global. 
Por fim, quanto ao objeto referente do liberalismo, entende-se a centralidade do indivíduo para tal tradição, o que nos levaria a concluir que ele seria o objeto referente. Porém, conforme veremos a seguir, embora sob um ponto de vista crítico, o papel do estado (que seria o objeto referente sob a concepção realista), no liberalismo, é o de proteger o indivíduo, e prover segurança para salvaguardar a sua liberdade.

\section{3}

\section{Segurança e Liberalismo Sob o Ponto de Vista Crítico}

Uma noção de segurança pautada no liberalismo está presente como alvo em grande parte na literatura crítica das Relações Internacionais acadêmicas. Tanto nos debates sobre o nexo segurança e desenvolvimento, que também será abordado nesse capítulo, quanto por autores que se debruçaram especificamente sobre como a guerra ou a segurança é tratada dentro do liberalismo, como é o caso de Mark Neocleous, Vivienne Jabri, além do próprio Mark Duffield.

A despeito da liberdade do indivíduo, valor central ao liberalismo tradicional, é tratada na obra de Neocleous (2008), Critique of Security, cujo argumento se centra no fato de que o cerne do liberalismo é a segurança, e não a liberdade, embora ela seja pregada incessantemente na retórica. A segurança tornou-se um paradigma, norteador de políticas em estados liberais. Sua presença discursiva é constante e se tornou um elemento cultural da vida cotidiana em estados liberais. O conceito foi imposto, e a palavra é veiculada nos meios de comunicação de modo frequente.

The extent to which the paradigm of (in)security has come to shape our imaginations and social being. 'Security consciousness' is the new dominant ideology; every day is Security Awareness Day (Neocleous, 2008, p. 3)

Neocleous (2008) discute o processo de ampliar e aprofundar o conceito, e sugere que foi insuficiente pela ausência de se examinar as implicações políticas, o real significado da segurança em si em nossas vidas, e colocar em cheque porque confere-se tamanha centralidade e foco a questão tanto no âmbito acadêmico quanto político. Em nenhum momento houve uma discussão profunda sobre o projeto da segurança em si. Discutir e pensar segurança significa discutir e pensar também o Estado e sua função. Neocleous (2008) crê que, mesmo nos 
estudos críticos da segurança, há pouca interrogação quanto a isso, pois tais elementos são ainda tidos como pressupostos. Ou seja, ainda há pouca desconstrução da própria noção de segurança.

O que nos importa para essa discussão é o quanto ela está relacionada ao liberalismo, a paz liberal e a sua crítica, e o quanto, na literatura e no discurso, principalmente, a segurança é vista como o que permitirá que a liberdade, a democracia, ou o desenvolvimento sejam possíveis. E, como, em última instância, o guardião da segurança ainda é o Estado. A saber, poder delegado a essa instituição ainda remete ao contrato social e a troca da liberdade pela segurança. Ou seja, a segurança se torna uma técnica de poder, conforme será colocado, em termos foucauldianos, tanto por Neocleous (2008) quanto por Duffield (2007). Reconstruir um estado, ou construir as instituições dentro de um processo de peacebuilding, tal como nos informa o liberalismo e o projeto da segurança, é conferir ao estado o poder de proteção. Para Neocleous (2008), isso permitiu com que uma ordem liberal fosse constituída - ou seja, construir e ordenar uma sociedade em nome da segurança, e não da liberdade individual. Veremos como tanto a segurança quanto o desenvolvimento são técnicas de poder do liberalismo para penetrar na vida humana - mas não necessariamente para levar a liberdade e o bem-estar, embora seja isso que o discurso prometa. Busca-se, primariamente, produzir a ordem, que levará à segurança. No caso dessa pesquisa, entende-se como a relação entre o norte e o sul, o ocidente e os países que recebem as missões e operações de paz.

Assim, a segurança pode ser entendida como uma forma de se impor ordem, de se reorganizar a política e moldar a sociedade. É uma narrativa, que confere forma às nossas vidas e nossas imaginações. É a segurança que é a chave do liberalismo, e não a liberdade (Neocleous, 2008, p. 7).

Outra noção de vital importância para a discussão se refere as situações de emergência, ou de exceção. As situações de emergência permitem a tomada de medidas ou de decisões de exceção, conforme já foi discutido no capítulo anterior. O 11/9 supostamente trouxe um estado de emergência permanente, que foi normalizado. Neocleous (2008) argumenta, que, na verdade, isso pode ter precedido os atentados: a ideia de segurança nacional já surge na década de 1940. O fio condutor do autor é de que no cerne do projeto de liberdade no liberalismo reside um projeto de segurança, muito embora o liberalismo tenha sido fundado 
como movimento e ideologia cujo carro chefe seria a liberdade do indivíduo. Os liberais seriam reconhecidos como os maiores defensores da liberdade.

Duffield (2007), cujo argumento se baseia largamente em Foucault, entende o liberalismo como uma tecnologia de governo que promove a liberdade, enquanto se governa as pessoas através de processos interconectados (econômicos, naturais e sociais), caracterizam as bases que sustentam a vida e pelas quais a biopolítica navega para pentetrar na vida nua. Assim, o ponto de referência do liberalismo é a vida e a liberdade das pessoas, de modo que a biopolítica, ou seja, a administração da vida da população, então, é uma condição necessária ao liberalismo (Duffield, 2007, p. 5). A biopolítica é disciplinadora e regulatória, e, acima de tudo, interventora.

Dessa maneira, Duffield (2007) e Neocleous (2008) concordam com o pensamento de Foucault, no que se refere à racionalidade governamental e à biopolítica: "the myth of a 'balance' between security and liberty opens the (back) door to an acceptance of all sorts of authoritarian security measures; measures which are then justified on liberal grounds. (Neocleous, 2008, p. 13)”,

O pensamento liberal moderno, cujas raízes se encontram em Hobbes e Locke (ou, no liberalismo clássico), nos permite questionar acerca de qual a real função da soberania: Segurança ou liberdade? Os dois partem do princípio do estado de natureza, inseguro, inseguranças geram o contrato social e o corpo soberano. Ora, para Hobbes, os seres humanos são regidos pelo próprio desejo, de modo que precisa-se de poder e de Estado autoritário para que a segurança seja garantida. Assim, o que daria origem à soberania seria a própria busca pela segurança, a qual era inexistente no estado de natureza, em que havia liberdade individual absoluta. Hobbes relata que ocorre a seguinte troca: obediência por proteção, que se equivale a uma troca de liberdade por segurança (Neocleous, 2008, p. 14).

Enquanto que, para Locke, entende-se que o estado de natureza é apenas um estado de absoluta liberdade, no qual não há qualquer poder absoluto ou arbitrário. No entanto, a ansiedade, o medo e a insegurança também são constantes entre os seres humanos. O contrato social seria, desse modo, uma busca por uma sociedade em que a liberdade possa ser assegurada, e, para tal, os indivíduos devem ter o pleno direito de dissolver o governo caso isso não ocorra. O que Neocleous $(2008$, p. 27) pretende com tal comparação é demonstrar que o 
senso comum costuma associar Locke com um ideal de liberdade. O autor, no entanto, argumenta que ele inaugura o discurso liberal da prioridade sobre a segurança. Ou seja, a prerrogativa seria de que o poder estaria nas mãos das pessoas, e a legislação cumpriria um papel de proteção, de segurança, e prevenção do poder arbitrário que coloque em risco a liberdade. Cabe ao poder executivo, em casos de emergência, o poder ilimitado para manutenção do Estado e para garantir a segurança. Assim, embora a legislação tenha importância, é o soberano, em última instância, quem é responsável por produzir e garantir a segurança. Com isso, Neocleous (2008) demonstra como que o projeto da segurança está presente no liberalismo desde suas raízes. A segurança já aparece aqui como a principal prioridade. Ela ultrapassa os limites impostos pelo estado de direito. Garantir a liberdade através da segurança é a prioridade indiscutível: "Far from being in opposition, the project of liberty supposedly announced with the onset of modern liberalism has been inextricably bound up in the project of security (Neocleous, 2008, p.22)".

Por uma genealogia do significado da liberdade para os liberais clássicos, Neocleous (2008) faz o mesmo movimento, e conclui que desde então os dois conceitos já estavam intimamente ligados. Eram quase que indissociáveis: segurança seria para assegurar a liberdade. Alguns, como Mill, acreditavam que a segurança vinha ainda antes da liberdade, em ordem de prioridade. Seres humanos não poderiam viver sem segurança; segurança da propriedade também seria essencial. São absolutos, preocupações que deveriam ser primárias a qualquer governo. Bentham dizia que a igualdade, baseada na distribuição de propriedades, era uma questão de segurança, e não necessariamente de liberdade. Já para Montesquieu,

[L]iberty 'consists in security or in one's opinion of one's security'. Liberty is thus a question of how we understand our security: 'political liberty consists in security or, at least, in the opinion one has of one's security'; 'political liberty in a citizen is that tranquillity of spirit which comes from the opinion each one has of his security'. (Neocleous, 2008, pag 25)

Observa-se que o que fundamenta a sociedade, portanto, seria a segurança: em última instância, é ela, apenas ela, quem garante a existência da sociedade em si. Liberta o indivíduo de preocupações, de ansiedades, pois o Estado cuidaria de tudo isso. E é precisamente daí que emerge a principal tensão do liberalismo, extensamente abordada por Foucaut: muito governo ou pouco governo? 
(Neocleous, 2008). Duffield (2007, p. 6) também chama atenção para essa problemática:

Too much government - in the form of state planning, for example, - and the dynamism and creative potential of the life processes on which freedom depends are destroyed. Governing too little, however, risks failing 'to establish the conditions of civility, order, productivity and national well-being which make limited government possible' (Rose 2000:70).

No que tange ao lugar da exceção no liberalismo, ou seja, de que todos os direitos fundamentais e liberdades individuais possam ser suspensas, em prol da necessidade de se garantir a segurança, já estava bastante evidente no liberalismo clássico, de acordo com Neocleous (2008). A segurança podia justificar qualquer ação fora do escopo político esperado, e ainda pode. Questiona-se, todavia, se a prerrogativa da exceção é de fato o bem estar do indivíduo e a proteção de sua liberdade, pois, em larga medida, a violência acaba sendo permitida e justificada nessas bases. Tudo a custo de se reestabelecer a ordem, através de todos os meios necessários, inclusive a violência. O que Neocleous (2008) coloca como conclusão em relação a isso é de que o estado de emergência é uma ordem de segurança que seria inteiramente compatível com o princípio da liberdade. Pois seria para assegurá-la.

Por fim, vale ressaltar a possibilidade do uso da exceção para o liberalismo. O modo pelo qual o liberalismo se apropria de situações de exceção e de emergência, se traduzem no que a escola de Copenhague chamará de o processo de securitização, conforme será abordado mais adiante. A securitização se baseia em transformar determinado acontecimento ou ameaça em uma questão de emergência, na qual qualquer medida pode ser adotada para proteger o objeto referente.

A despeito desse mesmo processo, Vivienne Jabri (2006) faz uma reflexão voltada ao papel das guerras no liberalismo e como elas compõem esse mesmo projeto de segurança. Ela contextualiza a normalização do estado de exceção como um processo que ocorre normalmente sob a alcunha de guerra. Para ela, as guerras, na verdade, permeiam a normalidade dos processos políticos, e através delas que se normaliza a exceção. Ou seja, transporta-se a emergência para a rotina, que foi o processo que o 11 de setembro ocasionou. 
War, rather than being confined to its own time and space, permeates the normality of the political process, has, in other words, a defining influence on elements considered to be constitutive of liberal democratic politics, including executive answerability, legislative scrutiny, a public sphere of discourse and interaction, equal citizenship under the law and, to follow liberal thinkers such as Habermas, political legitimacy based on free and equal communicative practices underpinning social solidarity (Habermas, 1997) (Jabri, 2006, p 49).

Outro elemento importante da análise de Jabri (2006) concerne a importância do discurso em tal processo. Tal como na securitização, é também através do discurso que se confere legitimidade a uma guerra e a um estado de exceção: a ameaça em questão deve ser legitimada. E aqui, mais uma vez, Jabri (2006) também concorda que a segurança, no liberalismo, existe para proteger a liberdade. Assim, a construção dos discursos se pautaria pela proteção e defesa da população. Porém, com isso, Jabri (2006) levanta uma crítica em relação a securitização, na medida em as guerras não são abordadas no quadro teórico proposto pela Escola de Copenhague.

O argumento de Jabri (2006) se baseia também no fato de que as guerras possuem matrizes: discursivas ou institucionais. Mas se centram na construção de um inimigo comum, de um ponto de antagonismo, ou seja, do estabelecimento de um outro nessa relação de proteção a ser criada. É o outro, o antagonista, que constitui o perigo real, e que permitirá com que medidas de qualquer tipo possam ser tomadas em nome da segurança. É um discurso calcado na exclusão, na distinção racial, o que foi muito evidente nos atentados terroristas de 2001, na questão em relação ao islamismo. Essa matriz de guerra, segundo ela (Jabri, 2006) é, na realidade, muito mais complexa, pois envolve uma série de práticas, dentre as quais, a violência: ela estaria imbricada nas relações de poder, como um modo específico de controle, e, por fim, como uma tecnologia de governamentalidade. Uma medida tomada em nome da segurança, justificada e legítima.

O que nos vale de Jabri (2006) para a discussão em questão é o enquadramento da situação de guerra dentro do escopo liberal, que enriquece a análise proposta pelos autores citados acima. A compreensão de que as medidas tomadas em nome da segurança - conforme será demonstrado, do Ocidente - são parte da ideologia liberal nos aponta a direção de que a paz liberal tem por detrás esses mesmos mecanismos. 


\section{4}

\section{A Expansão dos Estudos de Segurança}

Para Buzan \& Hansen (2012), os acadêmicos por trás da concepção tradicional de segurança mantiveram suas convicções estado-cêntricas para além da Guerra Fria, o que seria rejeitado, mais tarde, pelas linhas de alargamento e aprofundamento do conceito.

Os acadêmicos que propuseram uma expansão da agenda de pesquisa da subárea tomavam como pressuposto que o foco no Estado e nas ameaças militares a estreitavam e limitavam o campo de estudos, cujas origens estavam arraigadas nos estudos de defesa e de estratégia, o que ainda influenciava a agenda de pesquisa.

Além disso, Buzan \& Hansen (2012) enfatizavam também o caráter limitante da agenda, mas pelo seu cunho normativo e político, ou seja, que não apenas obedecia determinados interesses, de policy, como também os tinham como objetivo final.

Foi ao final da Guerra Fria, ou seja, com o fim do conflito bipolar e das ameaças nucleares constantes, que esses acadêmicos encontraram falhas e brechas que possibilitaram para uma ampliação da agenda de pesquisa, que encapsulasse essas novas variáveis. Como discutir a erupção de imigrações, epidemias de, por exemplo, AIDS, e ameaças ambientais se a disciplina não permite (Buzan \& Hansen, 2012)? Como explicar também os múltiplos conflitos intraestatais que haviam explodido durante a década de 1990? Ou ainda, conforme colocado pelos autores:
A era pós-Guerra Fria se definia pelo fato de que a bipolaridade, no sentido material e ideológico, desaparecia na medida em que a União Soviética iniciava sua mudança de identidade para um formato ideológico e militar menos ameaçador ao Ocidente, implodindo, mais tarde, e levando consigo a principal razão que legitimava a massiva competição militar (Buzan \& Hansen, 2012, p 246).

Assim, ficou explícito na academia que uma nova agenda de pesquisa deveria ser definida. O primeiro debate que emerge foi chamado por Buzan et. al (1998) de "The 'Wide' versus 'Narrow", ou seja, uma agenda ampla versus uma agenda estreita. Esse debate específico, conforme apontado pelo autor, tem seu início ainda antes do final da Guerra Fria, durante a década de 1980, com o 
aumento de preocupações sobre identidade, crimes transnacionais, e ameaças ambientais. O gatilho que impulsionaria tal discussão a todo vapor, então, foi a própria Guerra Fria. O debate é claramente exposto pelos autores na obra Security: A New Framework for Analysis.

Do lado dos tradicionalistas, o principal argumento contra ampliar a agenda de pesquisa era, principalmente, de que colocava em perigo a coerência da subárea, acrescentando mais de um significado à palavra, dando, assim, margem a ambiguidade. Acreditava-se que as temáticas militares e nucleares definiam o campo, pois, afinal, para Walt (1991), os estudos de segurança seriam sobre o fenômeno da guerra, através do estudo das ameaças e do uso e controle da força militar, conforme descrito no debate exposto pelos próprios Buzan et al (1998).

De fato, tradicionalmente, a subárea preocupava-se em abordar, quase que exclusivamente, assuntos de cunho estado-cêntrico e ligados a guerra e questões militares. O realismo sempre ocupou papel de destaque na agenda de pesquisa, de modo que isso se refletiu no fato de que a subárea enraizou-se nas tradições de power politics (Buzan et. al, 1998). Os tradicionalistas insistiram em defender maior especificidade à subárea, pois a ampliação faria com que se perdesse sua essência.

Porém, o que Buzan et al. (1998) constatam é que o final do embate bipolar trouxe também um período de desorientação. Tudo o que havia sido produzido e edificado durante o período anterior se viu estremecido e correndo o risco de perder sua validade. Mas os tradicionalistas não deixaram com que isso se tornasse um entrave: o conflito militar continuaria sendo absolutamente central para a concepção de segurança. Passariam a discutir, portanto, quais os motivos pelos quais a Guerra Fria teria chegado ao fim (Buzan \& Hansen, 2012).

O fato é que, com o fim da bipolaridade, muito do que o neorrealismo havia construído ao longo de toda a Guerra Fria, que segundo Buzan e Hansen (2012), foi um meta-evento para os tradicionalistas, havia sido posto em cheque. Sobretudo no que se refere ao pressuposto sistêmico: ele mostrou-se não permanente e suscetível a mudanças estruturais. Desse modo, o vácuo que se abriu com o final da bipolaridade trouxe à tona outro questionamento que nortearia os novos focos de uma possível agenda de pesquisa tradicional atualizada: qual seria a nova polaridade do sistema? (Buzan \& Hansen, 2012). 
Ampliar e aprofundar a Segurança foram dois processos que se desenvolveram através de diferentes vertentes das Relações Internacionais: foram acadêmicos pós-estruturalistas, feministas e construtivistas figuravam a lista de escolas que visavam arejar a subárea e desafiar os antigos pressupostos, defendendo que os tradicionalistas estavam inaptos a analisar, estudar e discutir as mudanças trazidas pelas décadas de 1980 e 1990 (Buzan \& Hansen, 2012).

Ao destrinchar tanto os aprofundadores e ampliadores dos estudos de segurança, figuram diversas escolas. Algumas delas serão explicadas abaixo, devido a contribuição delas ao argumento a ser desenvolvido no próximo capítulo. Outras escolas foram abordadas de maneira breve, não porque não merecem reconhecimento de suas devidas importâncias, mas porque não cabem na discussão aqui proposta.

No caso da Escola de Copenhagen, a proposta era de ampliar a agenda de Segurança, questionando a primazia dos elementos militar e estado-cêntrico, de modo que tanto a agenda como o próprio conceito não se limitem apenas ao entendimento do uso da força, da guerra, e questões relacionadas. Dessa maneira, a flexibilização da agenda permitiria com que novos temas e ameaças fossem incorporados a ela.

Para os estudos críticos, apenas ampliar as ameaças e os setores não se mostra o suficiente. O objeto de referência, para Buzan, e segundo os críticos, continuou sendo primariamente o Estado. Os críticos creem que isso continua limitando a agenda, e não permite a emancipação das estruturas consagradas. Desse modo, o que irão propor é que o objeto de referência se flexibilize de modo a incluir também o indivíduo, o que será de suma importância para o presente trabalho.

Por fim, a segurança humana emerge como um conceito institucionalizado, criado por policy-makers, pela ONU e atores não-governamentais também em resposta as mudanças causadas pelo fim da bipolaridade e pela explosão de novos conflitos que passariam a assolar os estados do Sul global. Tais vertentes serão abordadas nas próximas sessões. 


\section{5}

\section{A Securitização e a Escola de Copenhague}

A securitização emerge como literatura de alargamento da concepção de segurança, encabeçada por Buzan, e representada sobretudo pela obra "Security: A New Framework for Analysis", escrita em conjunto com Ole Wæver e Jaap de Wilde, em 1998.

O quadro proposto pelos autores estabelece, em primeiro lugar, o conceito de securitização: é uma versão extrema de um processo de politização. Em outras palavras, uma questão que passa pelo último processo faz parte de um escopo de políticas públicas, exige decisão e alocação de recursos por parte do governo. Assim, a securitização seria um processo em que "(...) the issue is presented as an existential threat, requiring emergency issues and justifying actions outside of normal bounds of political procedure (Buzan et al, 1998, p. 24)”. Ou seja, os autores afirmam que existe um espectro de ações entre os dois processos referidos, em que a politização se encontra em um lado, e a securitização em outro. Existe um caminho a ser percorrido para transformar uma questão em uma ameaça existencial. Porém, os dois processos não necessariamente ocorrem dentro do âmbito estatal. Os autores levantam a possibilidade de que outras entidades também poderiam categorizar questões como sendo de politização ou de securitização.

Uma questão ou problema, para ser securitizado, deve ser apresentado como ameaça existencial através do discurso. O discurso deverá sugerir que tal problema é mais importante do que outros, e que, assim, ele deverá ser priorizado e medidas especiais deverão ser tomadas em relação a ele. Porém, o processo de securitização só tem sucesso se há aceitação por parte da audiência. Assim, ao ator securitizador se confere o poder de tomar ações extraordinárias, permitindo com que determinadas regras sejam quebradas (Buzan et al, 1998). Assim, os autores creem que existe um claro caráter prático na Segurança - é uma prática em que determinada situação é apresentada como um problema de segurança, sobretudo através do discurso - e, assim, se torna um problema de fato.

Postas tais condições, Buzan et al (1998, p. 24), definem o ato de securitização da seguinte maneira: “(...) when a securitizing actor uses a rhetoric of existential threat and thereby takes an issue out of what under those conditions 
is "normal politics", we have a case of securitization". Acrescentam que tanto as definições quanto critérios para o ato se constituem a partir da determinação da ameaça intersubjetivamente. Porém, deve ser enfatizado aqui que, o ato apenas se dá por completo se há completa aceitação de um público em relação a ameaça existencial. A ameaça também deve legitimar a possibilidade de se quebrarem regras e de se tomar medidas extraordinárias. Deve ser colocada com devida argumentação para que a audiência se convença e aceite tais medidas. Desse modo, existe uma diferença evidente entre um movimento de securitização e a securitização que obteve sucesso (Buzan et al, 1998).

Uma das grandes contribuições do framework proposto pela Escola de Copenhagen é precisamente a sua proposta em ampliar a agenda no sentido de incorporar diversos tipos de ameaças, que não se restrinjam apenas a guerra e ao uso da força:

“(...) we want to construct a more radical view of security studies by exploring threats to referent objects, and the securitization of those threats, that are nonmilitary as well as military (Buzan et al, 1998, p. 4)". Em resposta aos tradicionalistas que os criticam, respondem que preferem manter a coerência da subárea ao se ater e explorar a lógica da segurança, de modo a encontrar e diferenciar o que é uma ameaça e qual o processo de securitização que ocorreu para determiná-la. A concepção tradicional não é rejeitada, mas sim, absorvida ao framework.

São definidos os setores dentro dos quais a securitização pode ocorrer, e é feita uma análise de como ela acontece para cada caso específico. Os setores abordados são: militar, ambiental, econômico, social e político. No entanto, vale ressaltar que cada setor existe dentro de um mesmo sistema e eles se interrelacionam. Para compreender a segurança, para os autores, devemos, portanto, desagregar os setores para entender suas particularidades e depois reuni-los. Segundo os autores, "We see sectors as a purely analytical device, as different lenses through which to see different views of the same issue" (Buzan et al., 1997, p. 168).

Buzan et al (1998, p. 36) estabeleceram as seguintes unidades para análise com base no quadro desenvolvido: 
1. Referent objects: things that are seen to be existentially threatened and that have a legitimate claim to survival;

2. Securitizing actors: actors who securitize issues by declaring something - a referent object - existentially threatened;

3. Functional actors: actors who affect the dynamics of a sector. Without being the referent object or the actor calling for security on behalf of the referent object, this is an actor who significantly influences decisions on the field of security. (...)

Para maior definição do quadro teórico e metodologia a serem utilizados, os autores apresentam quais níveis de análises serão utilizados para a obra. Níveis de análise são entendidos como referências ontológicas, objetos de análise, dentro dos quais os fatos ocorrem. São a localização tanto da fonte de explicação quanto dos resultados de um processo de securitização. Por ser um trabalho de abrangência multissetorial, o uso de níveis de análise é de extrema pertinência. Os níveis a serem utilizados, portanto, são: sistemas internacionais, subsistemas internacionais, unidades, subunidades e indivíduos. Eles proporcionam um quadro sobre o qual se pode teorizar (Buzan et al, 1998).

Já a análise de discurso para identificar processos securitizadores. Um problema é apenas securitizado com sucesso somente se é aceito como tal. Assim, ameaças existenciais, medidas emergenciais e efeitos nas relações interunidades compõe uma securitização bem sucedida. O processo pode tanto ser ad hoc quanto institucionalizado, e ele ocorre em larga medida através do discurso. Um governante, por exemplo, deve apresentar determinado problema como uma ameaça e deve gerar aceitação da sociedade. Existe, dessa maneira, uma necessidade de se legitimar a securitização através de argumentos que envolvam e convençam a sociedade da existência de determinada ameaça. É um ato de fala que, se houver aceitação, se traduzirá em ações efetivas e concretas (Buzan et al, 1998).

Por fim, é necessário fazer referência à importância da abordagem construtivista, que se deve ao fato de que através dela que se permitirá entender o processo pelo qual os problemas se tornam securitizados. Segurança é entendida como um tipo de política intersubjetiva, que não ocorre apenas por meio do uso da força. A adoção de tal abordagem é uma consequência de se ambicionar uma agenda ampla de estudos, que exige maior sofisticação em suas análises (Buzan et al, 1998). 
No que se refere a objeto de referência para a Escola de Copenhagen, muito embora abram a possibilidade para que outros possam ser considerados, ainda reconhecem, de certo modo, e não rejeitam, a centralidade do estado.

\section{6 \\ Os Estudos Críticos da Segurança e o Aprofundamento}

O aprofundamento dos estudos de Segurança, em linhas gerais, é o aprofundamento do objeto de referência, que desafia o estado-centrismo. Aprofundar implica também contestar o próprio conceito de segurança, na medida em que autores que propuseram ampliar (ou expandir), não desafiaram o real significado do conceito e suas implicações acadêmicas e políticas.

Dentre os expoentes do pós-estruturalismo, ou dos estudos críticos de Segurança, o primeiro autor de destaque a ser referido será Ken Booth, cuja obra "Critical Security Studies and World Politics" foi um marco ao propor o estudo da segurança e uma re-conceitualização como modo de emancipação.

Para Booth (2005), seu movimento é de aprofundamento: ele pensa sobre a concepção de segurança de cima para baixo, o que para ele significa desvelar e explorar "the implicaions of the idea that attitudes and behavior in relation to security are derivative of underlying and contested theories about the nature of world politics (Booth, 2005, p. 14)". Para o autor, esse modo de pensar levaria a construção dos estudos críticos de segurança, que se baseariam em uma ontologia que abrangesse outros objetos de referência, que não apenas o Estado, que incluísse indivíduos e a humanidade, uma epistemologia que buscasse engajar o que de fato ocorre na política mundial. O foco de sua orientação estaria nas práticas, a saber, no que ocorre na relação entre as ideias e as ações per se, e o que revelaria a chave para a emancipação, a maior contribuição do autor para a subárea. Booth (2005) aponta também que não deve haver confusão entre aprofundar e ampliar a concepção de segurança, pois o movimento de se ampliar pode, muitas vezes, se manter conservador pois não rejeita o tradicionalismo, e incorpora outros temas (ameaças) à agenda tradicional. Booth (2005) propõe um questionamento mais amplo, inclusive que ele seja feito em relação a todas as agendas de pesquisa. De modo que o objeto de referência seja, primariamente, o 
indivíduo - o que, segundo ele, não ocorre no trabalho de Buzan. Ou seja, Buzan ainda seria estado-cêntrico.

Em primeiro lugar, o autor situa suas críticas ao realismo (Booth, 2005, p.4) e contextualiza a sua contribuição ao debate conceitual:

Realism-derived security studies in the past half century has attempted to impose justo ne image of reality on a world that not only consists of many sovereign states but also is multicultural, divided by gender and class, and made up of individuals, families tribes, nations, and other subcollectivities; there are also some solidarities across all these (and other) subdivisions of humanity. The field of security studies, constructed out of political realism, continues to offer its students one image of reality, with predefined answers to key global questions.

Não apenas Booth (2005) crê que a agenda realista se limita a interesses específicos dos estados, mas também que há uma falta de realismo, embora o nome da escola seja esse. O autor crítica também a metodologia adotada pelos realistas, argumenta que falta sofisticação, falta crítica, pois toma seus pressupostos como dados. Além disso, é uma teoria estática, que não prevê o futuro, e não pressupõe dinamismo e mudanças nos cenários políticos. Critica também como a agenda é estreita, como marginaliza determinados elementos da política (por exemplo, as mulheres, os subalternos), a rigidez intelectual e sua ética.

Assim, sua obra se propõe a oferecer uma teoria de fato realista, que aborde todos os elementos que teriam sido deixado de lado pelo realismo, flexível, auto-reflexiva, aberta a mudanças (Booth, 2005, p. 11). Pretende ser progressiva, dinâmica, e promover a emancipação de indivíduos presos a estruturas tradicionais. Reconhece que existem mudanças, e que a História não é estática, e que ela deve sim ser levada em consideração.

Outra obra expoente dos estudos críticos seria a organizada por Keith Krause e Michael Williams (1997), Critical Security Studies, que também se debruça de maneira ampla e através de diversas abordagens em relação ao foco da segurança tradicional no Estado.

Conforme colocam os autores (Krause \& Williams, 1997), estudar a segurança sob as lentes de uma perspectiva ampla seria estender a gama de objetos de segurança, bem como do escopo de possibilidades de ameaça. Eles também acrescentam que os modos disponíveis para se assegurar a segurança 
devem ser estudados da mesma maneira. Isso se daria pelo fato das constantes mudanças que o mundo tem atravessado desde o final da Guerra Fria.

Além disso, em relação ao poder militar, creem que houve pouca discussão teórica sobre o tema mesmo entre os estudos críticos. Acreditam, portanto, que tal ponto deveria ser mais destrinchado, e que não deve haver apenas um silêncio em relação a isso, no processo de expansão e aprofundamento dos estudos de segurança. O mesmo se aplica sobre a questão da violência, que seria um ponto crucial, segundo os autores (Krause \& Williams, 1997).

Por fim, o que os últimos autores referidos pretendem com suas obras é, na verdade, promover um maior pluralismo nos estudos críticos da segurança, de modo a abarcar com profundidade temas que muitas vezes foram deixados de lado. Encorajam diversas abordagens ao invés de dar ênfase a apenas uma.

\section{7}

\section{O Nexo Segurança e Desenvolvimento}

É a partir do nexo entre segurança e desenvolvimento, expressivo na formulação de políticas a partir da década de 1990, que se originam as operações de peacebuilding. Seus formatos refletem essa articulação que foi amplamente difundida através de discursos da ONU e órgãos como USAID e DFID, tendo como norte a máxima de que desenvolvimento só pode ocorrer se houver segurança, e que sem segurança não pode haver desenvolvimento (Duffield, 2001; 2007; Stern \& Ojendal, 2010).

É nesse período que ganham destaque as noções de estados falidos, das novas guerras, e de que o desenvolvimento é uma grande ameaça à segurança e estabilidade internacionais. Esse discurso ganha força não apenas entre órgãos governamentais ou organizações internacionais, mas incorpora também as ONGs de ajuda humanitária, anteriormente ditas imparciais e neutras politicamente. A partir desse momento, passam a atuar em conjunto, e como fruto disso, passam também a ter coerência retórica (Duffield, 2001).

Estado falido foi um conceito que se manteve bastante em voga durante a década de 1990, e que foi retomado após os atentados do dia 11 de setembro de 2001. Seriam precisamente os estados falidos que deveriam ser consertados e readequados a um contexto liberal através do nexo entre segurança e 
desenvolvimento (Duffield, 2001; 2007). Foram diversos os estudos produzidos em busca de uma definição e de um conjunto de características levantadas para identificar o que constituiria um Estado falido. Carment et al (2011) propõem um framework teórico para os estados falidos, a partir de um estudo que procura fornecer uma síntese de definições em conjunto com estudos quantitativos.

Em resumo, observam as seguintes características em comum para tais estados: em primeiro lugar, são os estados que estão mais distantes de cumprir as metas do milênio estabelecidas pela ONU. A maioria de suas populações vive em estado de pobreza, os índices de mortalidade infantil são altos, a maioria das crianças não recebe educação formal, mais de $25 \%$ da população contraiu HIV, entre outros indicadores. Muito embora alguns de tais estados tenham até conseguido superar algum desses elementos, ainda apresentam instabilidade, estão sob conflito interno, ou o governo entrou em falência. Assim, outro elemento de importância para caracteriza-los seria o alto índice de violência. Muitos autores concordam que isso é um dos principais atributos para a falência de um Estado. A violência não necessariamente se explica pelos conflitos civis e políticos, mas sobretudo pela alta criminalidade que aflige tais locais. Isso indica falta de segurança interna no Estado, refletindo a falta de legitimidade do próprio governo. Essa noção passou a compor a retórica de discursos desenvolvimentistas a ganhou nova atenção com o 11 de setembro. Porém, a crítica é que tais definições estabelecidas por diversos autores são, além de profundamente normativas, vagas e apenas descritivas, ou seja, pouco analíticas (Carment et al, 2011).

Outro principal conceito para compreender a noção do nexo entre segurança e desenvolvimento seria o das novas guerras, na medida em que elas seriam o ponto focal das instabilidades e ameaças, e ocorreriam nos chamados estados falidos.

Em primeiro lugar, conforme Mary Kaldor (2001), em sua obra New and Old Wars, as novas guerras devem ser entendidas em meio a um contexto de globalização. O que, conforme a autora, é um processo de intensificação das conexões globais, sejam elas políticas, econômicas, militares ou culturais (Kaldor, 2001, p. 3). As novas guerras seriam também consequências diretas do final da Guerra Fria, que deixou como legado um vácuo de poder e um conturbado período de transição. Isso se refletiu também em um processo de erosão ou até mesmo desintegração da autonomia estatal em determinados contextos. 
Assim, acarretariam em situações de declínio da renda estatal e em colapso da economia local. Com isso, a criminalidade aumentaria, bem como a corrupção e a ineficiência estatal. Outro elemento central do argumento de Kaldor (2001) é a emergência da privatização da violência, o que caracterizaria tais novas guerras em contraposição com o processo de formação do estado moderno. Ou seja, enquanto em situações de declínio de Estados-nação, outras formas de violência (privadas) emergem, a origem dos estados modernos se caracterizou pelo processo de monopolização do uso da violência. Assim, se configura uma crise na legitimidade estatal pós Guerra Fria, dando margem para a multiplicação de novos conflitos.

Porém, Duffield (2001) é quem aprofunda e amplia a discussão ao incorporar o nexo segurança e desenvolvimento como um novo framework para as políticas da década de 1990. Segundo o autor, havia uma ilusão de que, com o final do conflito bipolar, haveria um período de paz e de estabilidade, o que se comprovou falso assim que estouraram diversos conflitos e crises humanitárias logo no começo da década. Tais acontecimentos se tornaram o centro das atenções tanto no âmbito das formulações de políticas internacionais e públicas, quanto na academia. No entanto, enquanto tradicionalmente conflitos e guerras eram temas quase que exclusivos da subárea da segurança, Duffield (2001, p.1) levanta que no campo do desenvolvimento e de formulação de políticas, passou-se a abordar também as implicações dos efeitos das guerras. O campo de desenvolvimento, por sua vez, conforme expõe Chandler (2007, p. 365):

While it would be wrong to argue that security and development were entirely separate policy areas prior to the end of the Cold War, their linkage was much more mediated, through the geo-political concerns of the time. Security concerns were largely focused on military threats to the geo-strategic interests of Western states while development policy was concerned with both supporting political allies and demonstrating confidence in market-based solutions to development blockages. While security and development policies were linked by shared overall geo-political concerns, each field projected these concerns in a clearly distinct way.

Assim, observa-se que isso logo impactou no entendimento da própria noção de segurança e se refletiu na multiplicidade de publicações de literatura sobre humanitarismo e conflitos, criação de departamentos em universidades, e criação de unidades em organizações internacionais, instituições financeiras internacionais, e governos nacionais preocupados em atender a falta de 
desenvolvimento do sul global que tanto ameaçaria a estabilidade do norte (Duffield, 2001). De fato, o nexo quase se tornou um consenso, conforme apontam Stern e Ojendal (2010, p. 5):

It is now beyond doubt that attention to the 'security-development nexus' has become commonplace in national and global policymaking. The 'securitydevelopment nexus' has also become the focus of key think-tanks, and of figures increasingly prominent in university-based research. In the emerging literature including the official 'report industry' - there is a seeming consensus that 'security' and 'development' are interconnected, and that their interrelationship is growing in significance given the evolving global political-economic landscape.

Duffield $(2001$; 2007) não rejeita a importância da globalização nesse processo. Ela supostamente seria responsável, ou, ao menos, teria cumprido papel relevante no crescimento de problemas como a pobreza, colapso ambiental, conflitos civis, crises sanitárias; todas elas necessitam administração. Caso contrário, se os países em tais condições se desestabilizarão e se tornarão um risco para a sociedade ocidental, conforme foi orquestrado e transformado em consenso internacional através do discurso ocidental: "It is felt that the increasing interconnectedness of the global system has magnified the threat of internationalisation of instability in the South. (Duffield, 2001, p. 37)".

Duffield (2001), bem como outros autores (Stern \& Ojendal, 2010; Chandler 2007) expõem como o nexo entre segurança e desenvolvimento foi utilizado para embaçar e confundir os limites entre os dois conceitos, mas de modo que pudesse ser utilizado como forte retórica política, que possibilitasse múltiplas ações e manobras dentro de tal escopo político. A amplitude do conceito permite certa mobilidade no discurso para atender diversos interesses. Além disso, Duffield (2001) acrescenta e conclui que, o resultado disso foi que a promoção do desenvolvimento acabou por se tornar sinônimo da busca interminável pela segurança.

A associação, que se tornou consensual, em resumo, permite concluir que não apenas o subdesenvolvimento e o conflito estão intimamente relacionados, como, por consequência, o conflito destrói o desenvolvimento (Duffield, 2001, p. 37). Ele também destrói estruturas, instituições, e para tanto, o desenvolvimento deve ser trazido para que possa promover transformações radicais em tais sociedades. Duffield $(2001 ; 2007)$ argumenta fortemente que há de fato um 
caráter radical dentro do projeto da paz liberal, conforme já foi explicitado no primeiro capítulo da presente dissertação. Por fim, uma das conclusões do autor aponta que um dos trunfos do nexo é que a noção cria um senso de urgência quanto ao subdesenvolvimento como ameaça, e se evidencia a necessidade de se transforma-lo e de remedia-lo. Assim, para articular com o que já foi exposto anteriormente nesse capítulo, “(...) development is better understood as a liberal technology of security for containing and managing the effects of underdevelopment. (Duffield, 2007, p. 24)".

Sob um ponto de vista prático, observa-se os reflexos do nexo durante a década de 1990, em que sua emergência como retórica política, aliado a evolução das operações de paz foram acompanhadas de diversas reformas normativas e institucionais no sistema internacional. $\mathrm{Na} \mathrm{ONU}$, por exemplo, novos departamentos foram criados para suprir a demanda de emergências humanitárias. Foi durante esse período que nasceram: o OCHA (Office for the Coordination of Humanitarian Affairs), o DPA (Department of Political Affairts), o DPKO (Departamento de Operações de Paz), e o OHCHR (Office of the High Commissioner for Human Rights) (Tschirgi, 2003).

\section{8 \\ Segurança Humana}

A necessidade de se ampliar a agenda de segurança ecoou entre organizações não-governamentais, entre políticos e dentro da própria ONU. Desse modo, o conceito de segurança humana também emerge a partir da ampliação do escopo dos estudos de segurança. Sua primeira aparição foi relatório do PNUD sobre desenvolvimento humano em 1994:

Traditional national security approaches have not been sufficiently sensitive towards conflicts that arise over cultural, ethnic and religious differences, as happened in Eastern Europe, Africa, and Central Asia in the post-cold war era. Another reason is the spread of democratization and the post-cold war emphasis on human rights and humanitarian interventions (Acharya, 2011, P. 482).

Buzan \& Hansen (2009) argumentam que uma das grandes vantagens desse conceito é o fato de ele ter sido promovido com uma forte base institucional. Acrescentam que a definição apresentada pelo PNUD foi formulada calcada em uma lógica de segurança que pretendia expandir os interesses 
nacionais de proteção do território e de armamentos nucleares, e que agora, a atenção deveria se focar em preocupações universais como prevenção de conflitos, o desenvolvimento e a erradicação da pobreza. Assim, isso indica uma mudança no objeto de referência, que se torna o indivíduo, as pessoas, a sociedade e seus direitos e liberdades. O que o conceito de segurança humana acrescenta também são novos elementos que podem ser tidos como ameaças (Buzan \& Hansen, 2009).

MacFarlane e Khong (2006, p. 13), por sua vez, afirmam que segurança implica a ausência de, ou a liberdade de, ameaças a valores basilares. Para os autores, estes seriam sobrevivência física, bem-estar e identidade. Portanto, segurança humana seria a ausência de ameaças aos valores essenciais aos indivíduos.

Acharya (2011, p. 481) aponta que o conceito ganha destaque nesse período, ou seja, a década de 1990, devido ao crescimento da incidência de guerras civis e conflitos intraestatais, que envolvem grandes números de mortes, limpezas étnicas, epidemias, e refugiados. Se vale de qual relação, de fato, o estado deve ter com sua própria população, e de qual o papel da soberania frente a eclosão de tais acontecimentos, sobretudo pelo caráter interno que apresentam.

O escopo do relatório (Acharya, 2011, p. 480) incluía sete áreas que comporiam o conceito de segurança humana. As áreas seriam: segurança econômica, ou seja, aquela baseada em uma renda básica garantida através de trabalho; a segurança alimentar, que assegura que todas as pessoas devem ter acesso a comida; a segurança de saúde, que garante a proteção mínima contra doenças; a segurança ambiental; a segurança pessoal, ou seja, a que protege as pessoas da violência física, independente de qual ator a conduz; a segurança comunitária; e, por fim, a política, que garante que os indivíduos vivam em uma sociedade que honre os direitos humanos e que garanta a liberdade política e de expressão.

Mary Kaldor (2007), em sua obra "Segurança Humana", argumenta em torno da existência de um gap de segurança, principalmente nas regiões que se encontram sob as novas guerras, segundo sua definição. No entanto, as concepções de segurança comumente utilizadas tanto na política quanto na academia não levam isso em consideração, e estreitam os debates. As novas guerras estariam permeadas pelo aumento de doenças, vulnerabilidade a desastres 
naturais, pobreza, entre outros. Tais concepções de segurança mainstream, ao invés de resolver e lidar diretamente com tais questões, muitas vezes acabam aumentando-as.

Hopper (2012) acrescenta que o conceito de segurança humana tem caráter multidimensional, uma vez que abrange desde preocupações ambientais, sociais e políticas. Os genocídios, porém, ofuscaram as outras preocupações, de modo que o foco passou a ser, em grande parte, no indivíduo, em grupos e comunidades.

Por fim, é necessário se fazer menção ao Canadá, que incorporou o conceito em sua agenda política durante a década de 1990 e passou a promovê-lo em sua política externa. Porém, sua concepção era uma crítica a do PNUD, que tinha pouco foco em aplicação política. Mas, mesmo assim, era uma noção ampla, que compreendia preocupações com direitos humanos, governança, mulheres em conflitos, operações de paz, desenvolvimento do direito internacional, conforme colocado por MacFarlane e Khong (2006, p. 173). Acrescentam que a visão de segurança adotada pelos governantes canadenses se baseava na ideia de que a segurança nacional era, em última instância, para garantir a segurança de seus habitantes, de modo que essa preocupação específica com a segurança humana acarretaria em maior legitimidade para o estado propriamente dito:

\footnotetext{
Canadian policymakers took the view that the security of the state was not an end in itself but was a means of ensuring security for people within its borders. Ensuring human security strengthened the legitimacy and stability and, therefore, the security of the state. Because of the increasing interdependence of states, concern for the safety of people extended beyond borders (MacFarlane \& Khong, 2006, p. 173).
}

Foi a partir dessa incorporação do conceito à agenda de política externa canadense que deram origem a rede de segurança humana, fundada em conjunto com a Noruega em 1999. A rede pretendia promover a proteção de crianças em situações de conflito, combater o crime organizado, controle de armas, educação, e preocupações com relação à saúde, tal como combate a AIDS. Seus membros agiriam tanto dentro quanto fora da ONU, promovendo a incorporação de todos esses elementos em diversas agendas políticas (MacFarlane \& Khong, 2006). No entanto, a concepção canadense também sofreu diversas críticas pois, tal como a do PNUD, foi considerada muito ampla. 


\section{3}

\section{As Práticas da Paz Liberal}

O presente capítulo apresentará duas ocasiões da prática da paz liberal, uma vez expostos todos os conceitos que a envolvem. A primeira situação nos indica como a paz liberal era implementada no período que antecedeu os atentados do 9/11. A segunda situação retrata quais as mudanças que os atentados acarretaram na prática das implementações políticas, e quais as diferenças em relação ao tratamento do humanitarismo em relação a década de 1990.

Isso reflete uma mudança de orientação da política internacional em relação a objeto referente, que, na década de 1990, se viu voltada a proteção do indivíduo, enquanto a década de 2000 aponta para um retorno a uma concepção tradicional de segurança, que remete ao objeto de referente sendo o estado nacional.

Trataremos aqui as operações de peacebuilding lideradas pela OTAN, que foram reconhecidas como missões de estabilização, e que ocorreram de maneiras similares no Afeganistão e, em seguida, no Iraque. 


\section{1 \\ Segurança Humana como Framework para Operações de Peacebuilding pré- 11/9}

Um dos fatores mais marcantes da década de 1990, como resultado do fim do conflito bipolar e a subsequente erupção das 'novas guerras', é que houve uma crescente mudança no objeto de segurança da política internacional.

A partir do final da década de 1980 e início da década de 1990 houve o processo de ampliação e aprofundamento da concepção de segurança. Isso se traduziu em um movimento em que a segurança estatal deixou de ser o único objeto de referência, e o indivíduo ganhou o holofote na retórica política internacional.

O final da Guerra Fria se deparou com um notável aumento na quantidade de intervenções humanitárias sobretudo as promovidas pela ONU. Isso reflete uma evolução normativa, no sentido de que, evitando se aproximar de um dos pólos de poder, a ONU não se comprometia com tais tipos de operação de maneira mais intensa. Além disso, o Conselho de Segurança estava praticamente congelado.

As guerras civis e emergências humanitárias trouxeram atenção às populações de tais estados, em especial dos que foram chamados de estados falidos. Segundo Duffield (2007), esse movimento foi claramente ilustrado através da emergência do conceito da segurança humana, que ganhou institucionalização e força discursiva.

Enquanto a soberania como norma legal se impunha também como limitadora das intervenções humanitárias através do princípio da não-intervenção, motivações morais e éticas se sobrepuseram e promoveram avanços e evoluções para que houvesse maior aceitação legal para com tais operações. Anteriormente, era aceito que questões internas fossem assunto quase que exclusivo do Estado em questão. A soberania e a não-intervenção eram dois assuntos praticamente invioláveis (Finnemore, 2003; Duffield, 2007; Hehir, 2012). A subsequente expansão da segurança humana, conforme Duffield (2010, p. 64) argumenta, foi a demonstração máxima dessa mudança crescente de objeto de referência - embora, conforme demonstrará Duffield e Richmond, seja sobretudo na retórica. 
Sob um ponto de vista crítico, Duffield (2007) entende a segurança humana como uma relação de governança que mobiliza tanto a segurança internacional quanto o desenvolvimento sustentável. Há uma distinção entre estados eficazes e estados ineficazes implícita no conceito. Acrescenta, ainda, que é uma tecnologia de biopolítica (Duffield, 2007; 2010):

Human security is a biopolitical category. It seeks to understand a world in which the geopolitical concerns of Northern states have been overlaid with a more diffuse and multiform threat associated with alienation, breakdown and insurgency emanating from the nominal populations of Southern states. Human security - the ability of people of former protectorates and colonies to enjoy complete and fulfilled lives - has moved from the shadows of domestic affairs onto the international political agenda (Duffield, 2007, p. 112).

Richmond (2006, p. 6) complementa que a segurança humana como bipolítica

(...) impact upon the most intimate aspects of human life. This is aimed at domesticating and normalising mainly non-western societies and communities caught up in humanitarian crises, bringing their political structures and socioeconomic interactions into a liberal peace and governance framework.

No caso da paz liberal, a autoridade associada a essa ideologia se torna o Norte. Através da governamentalidade, as práticas previstas na paz liberal se normalizam, em um processo de domesticação. Por ser visto como uma tecnologia para se governar populações, o conceito em si, tal como o nexo entre segurança e desenvolvimento, não se preocupa em ser objetivo e restrito. Muito pelo contrário, ser vago e ambíguo permite com que diferentes interesses, atores e relações de poder sejam articulados e incorporados ao discurso. Ou seja, o fato de que é controverso, por ser uma institucionalização de um conceito abrangente de segurança, Duffield (2007) diz que o discurso rapidamente penetrou no meio mainstream, tanto acadêmico quanto político. Ele mobiliza, integra e cria laços as vezes improváveis.

No que se refere a segurança, a segurança humana incorpora a segurança liberal, que foi apresentada na primeira sessão desse capítulo. O foco é no indivíduo, mas é o estado quem garante a sua segurança, que permite com que seja livre.

De fato, ela pressupõe a liberdade e os direitos do indivíduo, mas no componente da segurança dessa dualidade está implícita a ideia do perigo do subdesenvolvimento (Duffield, 2007, p. 115). Ela traz ao centro da agenda 
política questões que eram antes subordinadas, e atrelam ao problema da segurança, transformam-nas em ameaças: a pobreza, as crises sanitárias, os refugiados, os conflitos, entre outros. Além disso, acrescenta-se que o discurso esconde que, embora a segurança humana tenha sido encubada como parte do aprofundamento da concepção de segurança, critica-se que, na verdade, a segurança humana só tem coerência se entendida sob o contexto do estado nação moderno e soberano. Ora, o desenvolvimento deve ser feito através do estado: ele ainda é o centro das políticas de desenvolvimento. Ainda, o próprio relatório Agenda for Peace teria cristalizado essa noção, embora sob disfarce da mudança retórica do objeto de referência:

(...) the enduring importance of Agenda for Peace is that while prioritizing the security of people rather than the states, the ultimate responsibility for securing humans is passed back to the state. While speaking on behalf of people, freedom and rights, human security positions that state as the ultimate guarantor of those rights (Duffield, 2007, p. 121)

E, por fim, se sobrepõe, na prática, a noção de que é o Estado quem ainda tem mais peso entre essa dualidade de objetos de referência, inclusive no que tange a políticas de desenvolvimento (Duffield, 2007).

Oliver Richmond (2006) entende a segurança humana como um conceito essencialmente liberal, e a coloca ao lado de outros, tais como a democratização, o estado de direito, os direitos humanos e o mercado livre. Ele crê que todos esses conceitos dependem de serem legitimados ou não, e da aceitação pelos outros. Ele afirma também que é um conceito construído sobre a noção da existência do outro.

A segurança humana envolve uma gama de atores, como, por exemplo, doadores, ONGs, instituições financeiras internacionais, e organizações internacionais. Ela é tida como um conjunto de necessidades básicas, que são entendidas e construídas de acordo com um consenso liberal. Segundo o autor, a segurança humana também reflete a militarização da ajuda humanitária, bem como o nexo segurança e desenvolvimento. E, por fim, é a segurança humana que, dentro do framework da paz liberal, permitiria a implementação da paz civil (Richmond, 2006). 
Ele crê também que a atuação da segurança humana, seus conceitos e atores associados se dá em diversos níveis, e tal como Duffield (2007), promove laços e articulações.

A segurança humana em abordagens da paz liberal articula uma visão que promove, acima de tudo, o bem-estar social e a justiça, paralelos a construção de instituições e estruturas básicas para governança. A segurança humana confere maior força discursiva à paz liberal, para diferentes públicos, e consegue, assim, maior aceitação e legitimidade ao projeto. O discurso intervencionista ou de reconstrução adquire um caráter mais humanista, preocupado com bem-estar, e o desvincula com noções de mero exercício de poder ocidental (Richmond, 2006, p. $3)$.

Um dos efeitos do nexo entre segurança e desenvolvimento, e, principalmente, da aplicação da segurança humana no campo, foi que a provisão das necessidades básicas às populações foi privatizada, ou seja, as ONGs passaram a cumprir essa função (Richmond, 2006). Chandler (2007) também chamou atenção para esse fato, levantando que foi bastante cômodo para o sistema ONU, até mesmo retoricamente. Pregavam a segurança humana, mas empurravam tal responsabilidade as ONGs e evitavam um possível fardo. De todo modo, o que nos importa é que, bem como ressalta Richmond (2006), o controle de tais estratégias, sejam elas de governança de uma maneira mais ampla, ou da provisão das necessidades básicas, é feito por atores e agentes externos. Isso comprova como não basta a segurança humana estar ao centro da agenda política, pois na prática, os indivíduos locais que recebem tais ajudas pouco têm voz - a gama de interesses por trás de todo o projeto é muito maior e se sobrepõe a qualquer implicação real para as populações.

In this, it may well be that HS approaches and broader approaches to liberal peacebuilding need a more careful appraisal: clearly making the human being a referent for security laudable, but the liberal peace framework is far more heavily weighted towards state-building than toward civil society (Richmond, 2006, p. $10)$.

Durante a década de 1990, ocorreu uma notável mudança na essência do humanitarismo, que se politizou. A segurança humana, atrelada aos direitos humanos, e suas estratégias, são, conforme Richmond (2006), amplamente politizadas. Ou seja, fez parte do movimento em que o humanitarismo deixou de ser neutro, conforme sempre pregou, sobretudo salvaguardado pela Cruz 
Vermelha. Além disso, a segurança humana e os direitos humanos fazem parte da estratégia ocidental, como parte desse framework que molda a paz liberal, que, conforme foi apontado, é baseada no controle e na biopolítica.

Além disso, a partir do momento em que o humanitarismo toma partido em um conflito, ele abandona a sua neutralidade. Isso ficará ainda mais evidente após os atentados do 11/9, em que o humanitarismo adquire caráter militar sob a provisão das missões de estabilização.

\section{2 \\ As Diferentes Concepções de Segurança para as Operações de Paz e As Novas Operações de Estabilização}

No que tange a intervenções humanitárias, a segurança humana é um dos principais princípios por trás das intervenções humanitárias. Portanto, diferente de estabilizações, que serão discutidas na próxima sessão, o foco é essencialmente no indivíduo e em sua proteção. A soberania é flexibilizada em face de motivações éticas e morais que se sobrepõem ao princípio de não intervenção, para que vidas sejam salvas e tragédias maiores sejam evitadas

Diversos autores concordam que, depois dos atentados do dia 11 de setembro de 2001, houve uma nova mudança de objeto de referência na política. Enquanto durante a década de 1990 a segurança humana era destaque na retórica política, notou-se a adoção de concepções estadocêntricas novamente com os ataques terroristas. Houve um movimento retrógrado na agenda internacional, conforme aponta Tschirgi (2003, p.11). A Guerra ao Terror, decorrente dos atentados terroristas do dia 11 de setembro de 2011, foi encarada primariamente como uma ameaça militar, porque o terrorismo, segundo Tschirgi (2003), ainda era visto como uma ameaça

(...) diffuse, multifaceted threat, perpetrated mostly by mobile nonstate actors. While it utilizes military tools, its primary targets are civilian and it is designed to create psychological damage. Most significantly, terrorism grows exceptionally well in environments of underdevelopment, political repression, poor governance, social injustice and deep-rooted grievances (Tschirgi, 2003, p.11).

Isso se refletiu nas operações de peacebuilding que se sucederam após os atentados terroristas em Nova Iorque. A importância das operações de estabilização se deve por representarem a mudança de foco político decorrente dos 
atentados do dia 11 de setembro de 2001. Essas operações são caracterizadas, portanto, por recuperarem a preocupação sistêmica, ou seja, de ameaças à segurança internacional e estatal, vis-à-vis o foco no indivíduo, característica das intervenções humanitárias da década anterior. Barakat et al (2010) se referem a essa onda de estabilizações no Iraque e Afeganistão como uma "tradition of forgetting", pela retomada de modelos antigos, e pelo caráter altamente militar. Elas seriam a expressão última de um processo de militarização da assistência humanitária, baseado também em sua securitização, pautada no nexo entre segurança e desenvolvimento. Esse processo é bastante controverso, pois as ONGs, ditas neutras, perdem espaço, o setor militar passa a atuar em questões antes tratadas pelas ONGs, e a neutralidade e imparcialidade características do humanitarismo também são relegadas em favor de uma ação com objetivos explicitamente políticos.

Ainda é bastante evidente a existência de contradições em relação à definição do conceito propriamente dito, e são vários os debates que ocorrem na academia e nos think-tanks. Barakat et al (2010) salientam a ambiguidade do conceito, que depende, sobretudo, dos interesses de quem intervém. De qualquer modo, estabilizações são caracterizadas pela tentativa de se combinar modos militares e civis para aumentar suas respectivas efetividades. Ou seja, conforme apresentado no parágrafo anterior, elas são também um fruto do nexo segurança e desenvolvimento, que já foi discutido em sessões anteriores.

Vale ressaltar que cada Estado interventor apresenta uma definição particular para estabilização, embora exista convergência entre elas e objetivos comuns. Abaixo, estão transcritas as definições coletadas por Barakat et al (2010, p. 02) tal como propostas pelos órgãos do Reino Unido e dos Estados Unidos, respectivamente, responsáveis pelos processos de estabilização:

The United Kingdom government's Stabilisation Unit has defined stabilisation as 'the process of establishing peace and security in countries affected by conflict and instability' and as 'the promotion of peaceful political settlement to produce a legitimate indigenous government, which can better serve its people' (Stabilisation Unit, 2010). [...] Similarly, the UK military's treatise on the subject, Joint Doctrine Publication 3-40, emphasises the pursuit of a political settlement while also introducing specific sectors of intervention and responsibilities related to infrastructure, non-violent political processes and 'sustainable social and economic development' (Ministry of Defence, 2009, p. 239). [...] Adopting an understandably military-centric approach, the US Army and Marine Corps' Counterinsurgency Field Manual 3-24 identifies stability operations as one of the three separate components of COIN alongside offence and defence. It defines stabilisation as encapsulating forms of engagement more commonly associated with multilateral interventions, such as peace-support operations, reconstruction and nation-building (Sewall, 2007, p. xxiii). 
Alguns autores buscaram definições comuns e gerais para todos os casos. Robert Muggah (2010) reúne as convergências, em meio às ambiguidades geradas pelos diferentes discursos:

\begin{abstract}
Stabilisation can encompass direct military operations, the provision of security and policing equipment and the training of national personnel, investment in governance capacity, development and forms of government (usually featuring market economies and democratic elections), and the engagement of multinational firms, non-government organisations, and development aid agencies to provide relief assistance and promote infrastructure development.
\end{abstract}

A estabilização pode incluir operações militares, provisão de segurança, investimentos em capacidades de governança, desenvolvimento de infraestruturas, e assistência humanitária, bem como estratégias de contra insurgência, contraterrorismo e antinarcóticos. Por fim, seriam voltadas a trazer a estabilidade para áreas afetadas por conflitos armados.

Muggah (2010) argumenta que a tendência da agenda atual de estabilizações prevê ações, principalmente, em estados frágeis. De modo que isso se torna um claro indicador da priorização de um conceito muito estreito de segurança, que subordinam objetivos básicos de bem-estar do indivíduo (Collinson et al, 2010). As agências multilaterais defendem que tal fragilidade, que apresenta ameaça à segurança internacional, poderia ser tratada. Há uma crença, presente nos discursos, na possibilidade de se conter e consertar tais sociedades. Dessa maneira, a estabilização seria uma componente chave de uma agenda liberal, e de um projeto transformativo de paz liberal. É articulado também com a guerra ao terror, incorporando as agendas de contra insurgência. Não há como separar estabilizações da política devido a seus objetivos (Muggah, 2010).

Gordon (2010), ao discutir especificamente o modelo britânico de estabilização adotado no Afeganistão, também questiona as definições por trás de tal categoria de intervenção. Embora esteja agindo sob a mesma operação da OTAN, existem algumas diferenças entre o modelo americano. Nesse caso, o autor argumenta que as raízes de tal operação, conduzida pelos britânicos na região sul do Afeganistão (Helmand) estariam nos discursos sobre estados frágeis, que ganharam nova força após os eventos de 11 de setembro de 2001. Ele concorda também que a estabilização é um fruto da junção dos conceitos de segurança e desenvolvimento. Tal como como Muggah (2010), crê que as 
estabilizações levaram também a um fenômeno de securitização da assistência humanitária, através de sua militarização. A comprehensive approach, carro-chefe da missão britânica, se traduz na integração entre militar, político e desenvolvimento. Ela se pauta por quatro objetivos (four $p$ 's): prevenir ou conter conflitos violentos, proteger pessoas, bens, e instituições, promover processos políticos que levam a estabilidade, e preparar para o desenvolvimento em longo prazo.

A sua convergência com as operações dos Estados Unidos em outras províncias, e que estabelece as bases da missão de estabilização da OTAN no geral, e as legitimam, seria baseada pela busca por promover processos políticos relativamente inclusivos, capacitar o Estado para prover o mínimo de segurança necessário, e promover melhorias na infraestrutura básica (Gordon, 2010) O teste do modelo foi realizado em Helmand, e buscava trazer segurança e desenvolvimento para a capital da província. Porém, o overlap com assistência humanitária foi limitado, ainda que seja o lugar com maior produção de ópio do país. A ausência de ONGs foi bastante evidente. O que Gordon (2010) conclui com sua análise é que houve uma clara separação entre a assistência humanitária e a estabilização, e isso não é diferente do caso dos Estados Unidos.

A discussão sobre a tendência a militarização da assistência humanitária já havia sido feita por Pugh (1998) antes mesmo dos conflitos no Afeganistão e Iraque. O envolvimento militar nas atividades humanitárias estaria sendo contestado por minar os pressupostos básicos do humanitarismo clássico, a saber: a imparcialidade, a neutralidade, e a assistência sem discriminação política. Pugh (1998) crê que as organizações de ajuda humanitária foram, aos poucos, sofrendo erosões, e "perdendo a inocência". Devido à falta de recursos e de fundos, as ONGs não tiveram opção senão a se abrir para receber auxílio financeiro tanto de estados quanto de organizações privadas e internacionais. Além disso, pela sua atuação em lugares de risco, muitos princípios também sofreram modificações por uma questão de sobrevivência.

Nas operações de estabilização, as forças militares têm agido nos campos de atuação de tais agências, não apenas pela relutância de muitas delas em tomar partido em tais operações, mas também pela hostilidade dos conflitos e os perigos que colocam aos agentes. Tais forças, por serem agentes de governos, não são neutras justamente por esse motivo, corroborando a politização da assistência 
humanitária. Para críticos e para ativistas, isso seria uma contradição, enquanto outros defendem tais ações repudiando a passividade (Pugh, 1998).

Sob o ponto de vista de Collinson et al (2010), o papel da assistência humanitária em discursos de estabilização pode variar entre governos e suas respectivas agências e departamentos, por conta de suas diferentes orientações de política externa e de suas estruturas burocráticas. Nos Estados Unidos, enfatiza-se a assistência humanitária apenas como um instrumento nas intervenções, e não como prioridade ou como carro-chefe. O USAID é um órgão subordinado ao Departamento de Estado. No Reino Unido, por sua vez, o DFID é um órgão separado do Foreign Office (FCO). O DFID ainda objetiva manter a independência e imparcialidade, ligados ao humanitarismo clássico. Por fím, a abordagem da ONU depende da missão e de seu contexto, que pode tomar muitas formas.

Conclui-se que, em meio aos debates apresentados, a assistência humanitária em uma operação de estabilização, ao contrário do objetivo de uma intervenção humanitária propriamente dita, é tida como uma componente estratégica, sob a perspectiva do nexo entre desenvolvimento e segurança; nas intervenções, a lógica é contrária, ou seja, o desenvolvimento é uma das ferramentas, e não havia politização explícita. Assim, a transformação que tais operações (de estabilização) trouxeram foi a subordinação das práticas de assistência, o que implicou também na subordinação da preocupação com o indivíduo e seu bem-estar. 


\section{4 \\ Metodologia da Análise de Discurso}

Essa seção pretende fornecer os arcabouços teóricos para a condução de uma análise de discurso, que nos permitirá jogar luz e salientar a existência de uma grande lacuna entre retórica e prática. Desse modo, observaremos que a política é desenvolvida de maneira isolada e reticente em relação as reais necessidades do que ocorre no campo. Procuraremos analisar, no discurso, qual o seu objeto de referência: se é o indivíduo, conforme o projeto da paz liberal, sobretudo sob influência da segurança humana, promove, através de suas operações com foco no bem-estar, na segurança multifacetada, e na liberdade dessas populações.

Assim, o objetivo será o de ilustrar a reflexão desenvolvida, com base em textos e discursos políticos, e mostrar, através deles, a construção da realidade política, dos processos e da retórica que foram responsáveis pela implementação da prática tanto da paz liberal, de um modo mais amplo, quanto, mais tarde, do envio das tropas ocidentais ao Afeganistão.

Se houve, na prática, a produção de marginalizações e de exclusões ao longo dos 13 anos analisados, é porque houve, em primeiro lugar, um discurso e sua subsequente aceitação pública para que a implementação - envio das tropas e continuidade ao conflito - pudesse ocorrer. 
Além disso, a análise de discurso se demonstra eficaz na medida em que, empiricamente, nos permite descobertas e comprovações ou não sobre o que se desenvolveu ao longo da pesquisa.

Para que isso seja feito, no entanto, é necessário que uma breve discussão metodológica a respeito da análise de discurso seja feita, para que fiquem explicitadas quais escolhas metodológicas foram feitas para condução do presente estudo.

\section{1}

Metodologia e Pressupostos Teóricos da Análise de Discurso nas Relações Internacionais

A presente dissertação inclui, para fundamentar sua argumentação, uma breve análise de discursos selecionados que nos demonstrarão a construção discursiva desses objetos de referência da paz liberal, e para onde pendem no caso do Afeganistão. Sua inserção nesse capítulo se dá pois o estudo de caso sobre o país escolhido fornece o embasamento para que possa haver compreensão dos discursos específicos sobre a missão.

Nas Relações Internacionais, recentemente, o estudo dos discursos tem sido uma área bastante ativa, segundo Milliken (1999). Porém, a análise de discurso raramente está ligada a uma única escola ou grupo de acadêmicos. Nesse caso, ela tem sido utilizada de maneira ampla tanto por pós-estruturalistas, construtivistas, feministas e pós-modernistas (Milliken, 1999), embora a autora acredite que ainda exista muitos campos para serem explorados. Ela contempla o aspecto emergente dessa metodologia para as Relações Internacionais.

O programa de pesquisa da análise de discurso ainda tem barreiras quanto a sua legitimidade e aceitação frente a comunidade acadêmica das Relações Internacionais. Os teóricos ditos mainstream, por exemplo, demonstram resistência quanto ao seu uso em suas análises. Assim, muito embora o programa esteja em emergência, sua aceitação na academia ainda não é completa. Ela crê também que a análise de discurso é algo que pode integrar diversos pesquisadores, embora de origens diferentes. 
Por conta disso, o que Milliken (1999, p. 226) procura demonstrar ao longo de seus texto é que os acadêmicos se preocupam em manter rigor em suas pesquisas na medida em que, tal como outras escolas ou grupo de pesquisadores, também possuem um conjunto de compromissos teóricos que são responsáveis por organizar tais estudos e impor determinadas restrições, ainda que implícitas, conforme aponta Milliken (1999). A análise de discurso não segue, no entanto, o rigor científico de Kuhn, mas não significa que não tenha seus próprios paradigmas (Milliken, 1999, pp. 226). Tampouco invalida a importância que essa abordagem tem para as Relações Internacionais, por exemplo, e também não invalida o fato de que análises de discurso possam ser bem feitas e contribuírem de alguma maneira, cientificamente.

O primeiro compromisso teórico da análise de discurso, de natureza construtivista, toca no ponto de que discursos são entendidos como sistemas de significados, que, por sua vez, são responsáveis pela construção das realidades sociais. Os significados também são construídos pelas pessoas, através da língua e de outros sistemas. Na análise de discurso, é importante enfatizar a importância das relações entre as coisas nesses sistemas, que podem construir oposições binárias que geram hierarquias (Milliken, 1999, p. 229)

O segundo compromisso, de produtividade discursiva, é sobre como discursos produzem ou reproduzem o que eles próprios definem (Milliken, 1999). Eles possibilitam com que determinados regimes da verdade se operacionalizem. Além disso, discursos também abrem a possibilidade para a marginalização e a exclusão de diferentes identidades, bem como impossibilitam outros modos de ação. Milliken (1999, p. 229) acrescenta também que, discursos definem sujeitos, seus atos e suas práticas.

O terceiro compromisso diz respeito ao "play of practice", que,

Discourses operate as background capacities for persons to differentiate and identify things, giving them taken-for-granted qualities and attributes, and relating them to other objects. As background capacities, though, discourses do not exist 'out there' in the world; rather, they are structures that are actualized in their regular use by people of discursively ordered relationships in 'ready-at-hand language practices' or other modes of signification (Shapiro, 1989:11). This view of a discourse as 'a structure of meaning-in-use' implies that discursive studies must empirically analyse language practices (or their equivalents) in order to draw out a more general structure of relational distinctions and hierarchies that orders persons' knowledge about the things defined by the discourse (Weldes and Saco, 1996: 373). 
Por fim, para Milliken (1999), esses três compromissos teóricos são os pressupostos para uma análise de discurso que seja feita com rigor teórico e metodológico.

Roxanne Doty (1993, p. 298), enquanto preocupada com análises de política externa, observa que a grande maioria, ou, as análises mais convencionais, partem em busca de respostas para questões de "por quê" determinadas decisões resultam em determinados cursos de ação. Ou seja, são para explicar os motivos por trás de determinados resultados ou consequências. Porém, a crítica de Doty (1993) é justamente na falta de problematização desse tipo de questionamento, que parte de uma série de pressupostos que já são aceitos pela pessoa quem está conduzindo o estudo.

A autora, por outro lado, sugere que sua abordagem de práticas discursivas busca responder questões "how to", ou seja, procura explicar como determinado fato ocorreu, com ênfase na construção linguística da realidade, como parte de um sistema que gera sujeitos, objetos e mundos. Assim, ao se utilizar essa abordagem de análise discursiva, não se pressupõe que coisas já estivessem no lugar em que estão. Mas sim, de que agentes são construídos e se articulam através dos discursos (Doty, 1993). Além disso, ela acrescenta que através desse tipo de questionamento é possível também entender determinados aspectos do poder e de suas relações, que outros analistas convencionais costumam não abordar.

\section{2}

\section{Categorias Analíticas}

A análise de discurso que será feita terá como base as categorias analíticas e metodologias tais como propostas pelos seguintes autores: Barry Buzan et. al (1998), Jennifer Milliken (1999), e Roxanne Doty (1993). Essas categorias permitem rigor e organização na condução do estudo, e maior entendimento de como os discursos podem ser responsáveis pela construção de sujeitos e objetos.

A primeira categoria a ser utilizada, o objeto de referência, como categoria analítica, é fruto do trabalho de Buzan et al (1998) como parte do framework de securitização. Em primeiro lugar, o objeto de referência é definido como uma coletividade que é ameaçada existencialmente. É importante ressaltar que o projeto de Buzan et al (1998) envolve incorporar elementos do construtivismo aos 
estudos de segurança, o que implica em pressupor, por exemplo, que há intersubjetividade nos processos de segurança. Pois o processo da securitização se dá, em primeiro lugar, através do ato da fala. Além disso, a percepção do que é ou não uma ameaça é dependente de uma relação socialmente constituída, conforme os autores exemplificam através do caso tanques ultrapassando fronteiras:

Our argument is that securitization, like politicization, has to be understoond as an essentially intersubjective process. Even if one wanted to take a more objectivist approach, it is unclear how this could be done except in cases in which the threat is unambiguous and immediate. (An example would be hostile tanks crossing the border; even here, "hostile" is an attribute not of the vehicle but of the socially constituted relationship. A foreign tank could be part of the peacekeeping force) (Buzan et al, 1998, p. 30).

Aqui já se atenta para como ocorre a construção discursiva, e predicados sendo utilizados como atributos, e no que isso pode implicar ou não. Esse elemento será abordado a seguir, quando discutiremos a respeito dos predicativos segundo Doty e Milliken.

Ainda a despeito do objeto de referência, uma das categorias de análise chave para o trabalho em questão, os autores ressaltam que:" The referent object is that to which one can point and say, 'It has to survive, therefore it is necessary to...'; (Buzan et al, 1998, p. 36).” No framework proposto pelos autores, entende-se que é um ator securitizador que declara que determinado objeto está ameaçado existencialmente - ou seja, é ele quem define qual é o objeto de referência.

Por fim, complementa-se que o caráter intersubjetivo dos processos securitizadores dependem, em última instância, da aceitação de um público para qual o discurso foi direcionado.

A despeito da análise de discurso feita com base em predicativos, para Milliken (1999, p. 231), é tido como o método mais adequado para o estudo do uso da linguagem em textos políticos, que é o caso do que será feito aqui.

A análise de predicativos se baseia em observar determinadas práticas linguísticas e como fazem uso dos predicativos. Ao analisar discursos, tais práticas envolvem a combinação de determinadas qualidades e atributos a sujeitos particulares. No texto, ocorre através do uso de predicados, advérbios e adjetivos que modificam os sujeitos. Tais combinações constroem realidades, conferem capacidades ou atributos a objetos ou sujeitos (Doty, 1993; Milliken, 1999).

Quanto aos pressupostos como categoria analítica, é procurar que tipo de conhecimento foi utilizado como arcabouço ou base para o discurso em questão. 
Os pressupostos devem ser questionados, e não aceitos ou deixados de lado em um estudo. Uma análise que se preocupa em observar os pressupostos pode, por exemplo, expor determinadas relações de poder intrínsecas ao texto (Doty, 1993).

Por fim, a última categoria, também proposta por Doty (1999) se preocupa com o posicionamento dos sujeitos no texto. Deve-se desconstruir o discurso e observar como cada termo é colocado, se existem relações de oposição, de similaridade, ou de complementaridade, a partir das qualidades e atributos. O que Doty (1993) ressalta para suas categorias é que o que deve ser analisado muitas vezes está bastante explícito nos textos, basta que utilizemos tal abordagem para desconstrui-lo e encontrar as respostas para as questões propostas.

\section{3}

\section{Escolha das Fontes}

A primeira fonte a ser analisada é o Acordo de Bonn, que foi firmado na ONU, em dezembro de 2001, em vistas de se estabelecer as bases para a resolução do conflito no Afeganistão,

Já em relação a presença dos Estados Unidos e da OTAN no Afeganistão, as buscas nas bases de dados disponíveis para o público foram feitas a partir das seguintes palavras-chave: Afeganistão, segurança nacional, afegãos, população, ISAF. As palavras utilizadas foram escolhidas por serem mais eficazes para filtrar os discursos que atenderiam as necessidades dessa pesquisa.

Também foram selecionados materiais representativos quanto a participação do governo britânico nas missões: como aliado dos EUA na Operation Enduring Freedom, e mais tarde, como membro da ISAF, e, por fim, como responsável pela PRT (Provincial Reconstruction Team) na província de maior índice de produção de ópio do Afeganistão - Helmand. Assim, o Reino Unido foi um ator de suma importância no conflito, sobretudo no que diz respeito ao combate da produção do ópio. Tais materiais não necessariamente se restringem a discursos oficiais, mas se expandem para importantes veículos de comunicação e de informação das instâncias do governo, como seus websites, que se propõe a informar publicamente sobre políticas.

Marcos temporais também foram utilizados para selecionar os textos a serem analisados. O principal marco que restringe a pesquisa se dá entre 2001, quando 
os Estados Unidos e aliados entraram no Afeganistão pela Operation Enduring Freedom, até 2014, fim das operações da ISAF. Outro marco que denota mudanças e que foi selecionado para filtrar os discursos são: 2009, primeiro ano de mandato do presidente Barack Obama, em vistas de se identificar se houve alguma mudança retórica ou não, no que concerne ao conflito no Afeganistão. 


\section{5 \\ Segurança e Ópio no Afeganistão}

O presente capítulo se propõe a fornecer um estudo de caso que ilustre a problemática apresentada durante o trabalho. Tendo como base a argumentação que foi desenvolvida no capítulo anterior, aqui observaremos em que situação ela se aplica. No caso, a missão dos Estados Unidos e da OTAN no Afeganistão sob o contexto da Guerra ao Terror, de 2001 a 2014.

O Afeganistão foi escolhido por ter sido considerado emblemático para compreender as reais preocupações por trás do projeto da paz liberal. O conflito também representa uma virada, ou talvez um desequilíbrio, na concorrência entre objetos de referência, que pende mais para o lado dos estados mandantes, vis-à-vis preocupações humanitárias. Não apenas pelo caráter da missão empreendida, mas também, conforme será abordado nesse mesmo capítulo, por uma problemática singular que sinaliza tal subordinação do bem-estar do indivíduo em meio a tal conflito: o boom da produção de opiáceos no Afeganistão desde a entrada da OTAN no pais.

Será ressaltado ao longo do capitulo que sua formação como Estadonacional moderno foi pautada por tortuosas interações com o sistema internacional, que se deram através de intervenções de seus vizinhos e de potências hegemônicas, que sempre terminaram em fracassos, sobretudo decorrentes da notável resistência do povo afegão. Ou, ainda, conforme resume Rashid (1999, p 23): 
For Afghanistan to be at the center of both dialogue and conflict between civilizations is nothing new. The country's location at the crossroads between Iran, Central Asia, the Arabian Sea, and India has given its mountain passes a strategic significance for countries. At certain times, Afghanistan has acted as a buffer between competing empires and ideologies; at others it has served as a corridor through which armies marched. Repeated efforts to colonize the country, most recently by the British and the Soviets, have failed and in the process given the Afghans a fierce sense of independence and pride.

Ou seja, a origem do país remonta à criação de um estado tampão entre os impérios russo e britânicos, que, mais tarde, viria a se tornar um espaço de disputa durante a Guerra Fria. (Rubin, 2007).

Mas essas não foram as únicas dificuldades sofridas. Como foi dito, o Afeganistão foi criado. Suas fronteiras foram desenhadas de acordo com o interesse britânico e russo, portanto, impostas e artificiais (Rubin, 2007).

Como resultado desse processo de imposição, o Afeganistão sempre sofreu para se erigir como um estado-nação sob os moldes ocidentais, e, desde 1919 até hoje, tem dificuldades para extrair renda e recursos do próprio território:

Because the government, then as now, was unable to extract enough revenue from this barren territory to rule it, its function had more to do with enabling an elite subsidized by aid to control the territory as part of the defense of foreign empires than with providing security and governance to the people of Afghanistan (Rubin, 2007, p. 62).

Uma das fases mais violentas do Afeganistão ocorreu após a retirada das tropas soviéticas do país, deixando-o em meio a um vácuo de poder, sem um Estado propriamente dito e legítimo, economia devastada, e diversos grupos armados espalhados pelo país. Foi então que o Afeganistão se afundou em uma longa guerra civil, que mais tarde permitiria com que o Talibã emergisse e evoluísse com rapidez (Rubin, 2007). Durante esse período, o Afeganistão ficou às margens do sistema internacional, e a ele foi conferida a alcunha de estado falido:

Afghanistan became, in the lingo of the time, a "failed state", where Afghans suffered from a "humanitarian emergency". For the United States and other major powers, Afghanistan became an object of charity and neglect, not necessarily in that order. Regional powers, especially Pakistan, but also private networks smugglers, drug dealers, and terrorists- treated it as an open field for manipulation and exploitation. (Rubin, 2007, p. x).

Os atentados do dia 11 de setembro de 2001 em Nova Iorque, atribuídos a al-Qaeda, revelaram esse isolado país incrustado entre montanhas na Ásia Central 
como uma das regiões mais instáveis do mundo, e trouxeram-no de volta ao centro do palco da política internacional.

Assim, com base na formação do estado afegão, entenderemos porque o país se tornou o maior produtor de ópio do mundo - fato que se consolidou após a entrada da OTAN e dos EUA no país, e de que maneira isso aponta para um desequilíbrio na dualidade de objetos de referência por trás da paz liberal, que se traduz em missões de peacebuilding.

\section{1}

\section{Um Panorama Histórico do Afeganistão}

Essa sessão se destinará a entender o processo evolutivo da formação do estado afegão e de suas particularidades. Veremos como os autores apontam, por exemplo, para a dificuldade em se enquadrá-lo sob uma definição weberiana de estado-nação, e como foi construído em cima de bases pouco sólidas, pois foi uma tentativa forçada de se criar um estado onde conviviam várias tribos e etnias distintas. $\mathrm{Ou}$, ainda, conforme resume Goodhand:

Many of the features of the current political economy have strong continuities with the past. The state in Afghanistan was built upon shaky foundations. Internal processes of colonization were never completed because rulers lacked the military force to subdue the tribes or withstand external aggression. Territorial sovereignty was an ideal to which Aighan rulers aspired but rarely if ever achieved in practice. In fact, for most of Ai'i^han history there was no state in any robust sense of the term. There were instead multiple sovereigns including smallscale local chiefs, tribal confederations, bandits or warlords (Goodhand, 2004, p. 156)

Além disso, discutiremos sobre seu processo de modernização, como tal tentativa foi inspirada por modelos ocidentais. Em seguida, como tal processo culminou em evoluções políticas, e, mais tarde, na ocupação soviética. Por fim, os motivos da guerra civil logo após a ocupação serão explicados, bem como a emergência do Talibã.

\subsection{1}

\section{A Formação do Estado Afegão}

É indispensável a compreensão do complexo passado afegão para se ter noção do conflito atual. Sobretudo para explicar quais as dificuldades em se 
implementar ou reconstruir o estado e suas instituições, e também para jogar luz sobre a origem da produção dos opiáceos. Na literatura atual, a atenção que é dada as suas origens é insuficiente. Desse modo, essa sessão pretende, ainda que não de maneira exaustiva, traçar um panorama histórico do país tendo como norte seu processo de formação como estado. A narrativa que será apresentada será construída de modo a ressaltar como, em diversas ocasiões, os indivíduos foram relegados às margens em todas as tentativas de imposição de um estado sob moldes ocidentais. As tentativas não se provaram adequadas para prover, de fato, bem-estar: aqui, não em seu sentido liberal, e sim, de modo em que haja emancipação, liberdade e ausência de conflitos para seus habitantes, bem como um sistema político que esteja enraizado em sua sociedade local, que garanta identidade, coesão social e legitimação dos contratos sociais (Pugh, 2005). Deve ser ressaltado, no entanto, que tal narrativa que será descrita a seguir não deve ser tida como verdade absoluta, mas sim, como opções feitas pelos autores escolhidos. Há escassez de materiais traduzidos que sejam originários do próprio Afeganistão, de modo que, para esse trabalho, adotamos literaturas majoritariamente ocidentais, mas que se aproximam do ponto de vista que se procura defender e construir ao longo da pesquisa.

Em primeiro lugar, o autor Hyman (2002) caracteriza o processo como tortuoso, pois ele foi marcado por tentativas de se unificar diferentes etnias, grupos linguísticos e tribos, de raízes históricas distintas, que foram obrigadas a conviver sob um único governo centralizado. A composição étnica do Afeganistão era, e de certa forma ainda é, formada pela reunião de tribos pashtuns, que contabilizavam mais de $50 \%$ da população, de tadjiques, usbeques, hazaras e turcomenos, embora em menor escala, se comparados aos primeiros. Segundo outro autor, Goodson (1998, p. 270), esses grupos, sobretudo os pashtuns, eram organizados em "a social system that emphasized loyalty to the social group, rather than a higher-order abstraction like the state". Em resumo, a sociedade afegã estava enraizada em uma estrutura tribal, na qual os grupos de diferentes origens étnicas se configuravam de maneira dispersa pelo território acidentado e, portanto, de difícil acesso. Obedeciam poderes estritamente locais, que refletiam as rivalidades existentes entre as lideranças tribais. Essa estrutura, somada à difícil geografia da região, contribuíram como um dos entraves para 
implementação (forçada) de um estado-nação já enfraquecido e pouco centralizado.

No que tange a geografia do Afeganistão, Rubin (2007) destaca as dificuldades que ela representa tanto por isolar determinadas regiões quanto pela falta de vastas planícies férteis. O território afegão é caracterizado principalmente pela sua maioria ser ocupada por amplas cadeias de montanha, desertos, e alguns poucos vales férteis e rios. O autor aponta que, essa configuração implica que, de fato, conforme foi dito no parágrafo anterior, as diferentes sociedades dificilmente coabitavam mesmas regiões. Cada uma vivia em determinado ponto isolada da outra - de modo que o Afeganistão só viria a se tornar um estado unificado se houvesse interferência externa: "Only their incorporation into a state has made them into a single society" (Rubin, 2007, p. 22).

Com base no que foi apresentado até agora, o que Rubin $(1988 ; 2007)$ questiona, ao longo de sua obra, é se o estado afegão poderia ser enquadrado, de fato, sob a definição de um estado nação moderno e soberano - ou, ainda, ao modelo ocidental. Sua obra de maior expressividade até carrega um título emblemático: A Fragmentação do Afeganistão.

No que concerne ao seu próprio entendimento de estado, Rubin (1988), em artigo anterior, expõe que:

To call the Afghan state a 'state', however, may mislead the uninformed Westerner (or Russian). 'State' conjures up the image of an organization whose law and regulations structure the interaction and guide the common affairs of its citizens who, however else may be divided, are united in their membership in and attachment to the historical and territorial community that the state represents (Rubin, 1988, p. 1188).

Seu estudo sobre a formação do estado afegão é introduzido através de uma detalhada discussão que compreende desde a noção de formação de um estado-nação territorial e soberano, com base em autores da ciência política moderna, para construir sua argumentação de que o suposto estado afegão, é, na realidade, 'fragmentado' sob o ponto de vista ocidental (Rubin, 2007). Seu argumento ressalta o caráter tradicional da sociedade afegã, constituída a partir de tribos, e demonstra através da literatura que a Europa feudal não era organizada dessa maneira: ao citar Tilly, Rubin (2007) descreve que se formaram a partir de disputas e guerras entre cidades - e que não eram entre tribos. 
A obra de Tilly, de suma importância para a ciência política e para o entendimento dos processos de formação do estado moderno, se centra na combinação entre efeitos do capital e coerção e como geraram diferentes tipos de estados, e na importância dos impactos da guerra para esse processo. Quando os meios de acumulação e de concentração de coerção crescem juntos, tornam-se estados. No que diz respeito às guerras, a sua preparação, em especial nas de larga escala, envolvem extração no sentido de que se constrói uma infraestrutura de taxação, de fornecimento, administração que requerem manutenção e crescem muitas vezes mais rápido do que exército e marinha. Assim, "Within the limits set by the demands and rewards of other states, extraction and struggle over the means of war created the central organizational structures of states" (Tilly, 1990, p. 15). Era mais fácil manter, administrar e aumentar exército quando o capital já estava concentrado. Tilly se concentra, portanto, em focar sua análise na organização da coerção e na preparação para a guerra, e documenta que a estrutura estatal é um produto dos esforços dos soberanos ou governantes em adquirir recursos para a guerra. Ou, conforme resume Rubin $(2007$, p. 6):

The nation-state developed in the cities and on the battlefields of early modern Europe. Feudal Europe contained both multiple centers of military power- states or would be states - and a dense network of cities, the loci of capital accumulation. Because no state grew large enough to subordinate the others in an empire, continual military competition led rulers to seek to strengthen their armies. The accumulation and mobility of capital, together with the development of industry and its application to warmaking, changed the relation of states to the economy. Unlike traditional empires, where expansion of the resource base of the state depended mainly on the conquest of trade routes or agricultural regions, states now relied on the accumulation of productive capital and technology in cities. Relative success in these ventures determined which states prevailed, survived, and founded the state.

Rubin (2007) percorre esse caminho ao decorrer de sua argumentação e salienta que, embora chame o Afeganistão de estado-nação, não necessariamente corresponderá a essa definição restrita desenvolvida desde Weber. Mas servirá a função de ressaltar que a incorporação do Afeganistão no sistema internacional moderno foi artificial, e para atestar que sua origem não se assemelha de maneira alguma aos processos ocidentais. Isso, segundo ele, pode ter sido um dos motivos responsáveis pelos conflitos que assolaram essa nação. E aponta, também, para a tendência que o Afeganistão seguiu ao longo de sua história de incapacidade de gerar capital e extrair recursos. 
A despeito do processo histórico em si, o Afeganistão moderno foi palco de disputas entre o Império Britânico e o Império Russo durante a transição entre o século XIX e XX, eventos que também ficaram conhecidos como o Grande Jogo entre os dois poderes. Como um território localizado entre as margens dos dois impérios, ao Afeganistão foi imposto o modelo ocidental de estado-nação, quando tanto um quanto o outro tentavam adentrar suas fronteiras. Conferiram ao Afeganistão status de "estado-tampão", e, a partir de então, estaria à mercê das vontades principalmente britânicas (Rubin, 1988). Essa foi a primeira tentativa de se incorporá-lo ao sistema internacional de fato.

Conforme já foi descrito, o Afeganistão consistia em tribos e etnias espalhadas e isoladas entre si, em meio ao território montanhoso - mas não havia sido incorporado a nenhum dos impérios anteriormente, fossem os impérios hindus e persas, e em seguida, russo e britânico. O mais próximo que existia de alguma configuração homogênea era uma confederação de tribos pashtuns - que se expandiam e se moviam pela região em busca de recursos e de terras férteis. Rubin (1988, p. 1192) observa:

Although this empire was the virtual antithesis of the nation-state, it nevertheless shared several key characteristics with the later state of Afghanistan, and it remains for many tribal Pashtuns the model of what an Afghan state ought to be.

Duas guerras aconteceram entre o Império Britânico e o então Afeganistão. A primeira, entre os anos de 1839 e 1842, foi um desastre para os britânicos. Porém, a segunda guerra, de 1878 a 1890, que levou o rei Amir Abdur Raman Khan ao trono, conferiu o direito aos britânicos de controlar a política externa afegã. $\mathrm{O}$ acordo firmado ao o final do conflito também estabelecia de maneira oficial a polêmica fronteira entre Afeganistão e Índia. A Linha Durand dividia os Pashtuns do Afeganistão dos Pashtuns da Índia, região que futuramente se tornaria o Paquistão (Rubin, 1988).

A partir de então, o rei afegão estava face ao grande desafio de centralizar o estado afegão, e unir as diferentes etnias e tribos que habitavam a região sob as recém-criadas fronteiras. A busca pela legitimação de seu próprio poder foi violenta: por ser pashtun, precisava do reconhecimento dos outros povos.

The campaigns to impose central rule and authority over formerly autonomous areas of Afghanistan varied in intensity and ferocity. In the southeast, in the region later known as Nuristan, where the indigenous tribes of "Kafris" were forcibly converted to Islam, the campaigns were relatively mild. But in the large mountainous central region of Hazarajat, where tribes of Hazaras were despised 
as Shi'i Muslim heretics by the Sunni Pashtuns, the defeated inhabitants were cruelly dispossessed of their lands and often enslaved; and in the north the Uzbeks, Turkmen, and Persian-speaking Tajiks were brutally brought under control, with rich lands taken by Pashtun settlers (Hyman, 2002, p. 306).

Para alguns autores, foi praticamente um processo colonizador pashtun (Shahrani, 2002) - e inteiramente financiado pelos britânicos. Já Habibullah, o sucessor de tal rei afegão, foi responsável por iniciar a modernização do recente estado sob os moldes ocidentais. Durante essa nova fase, entre 1901 a 1919, uma classe de intelectuais se desenvolveu pela primeira vez na história moderna do Afeganistão. Estes tiveram a chance de estudar no exterior e importar seus conhecimentos adquiridos sobre o funcionamento de um estado moderno europeu. Porém, Habibullah não abriria mão de cortar os laços com os britânicos, o que gerava grande desconforto diante dessa nova classe política. Mais tarde, isso levou ao seu assassinato em 1919, e seu filho, Amanullah, assume o poder (Rubin, 1988). Assim, é apenas nesse ano que o Afeganistão conquista independência completa do Império Britânico, a pedidos de Amanullah, que já estava envolvido na movimentação política pró-independência, antes mesmo da morte do pai. O pedido, no entanto, foi a princípio negado e houve um breve conflito (Rubin, 1988).

Foi então a partir de 1919 que o Afeganistão passou a desenvolver suas próprias relações diplomáticas com outros países. Assim, com a evolução de uma política externa própria, novos laços foram criados com outros países da Europa. Os frutos disso geraram escolas, universidades, expansão do comércio e ajuda financeira, uma vez que não tinham mais suporte britânico (Hyman, 2002). Além disso, Amanullah implementou reformas liberais, como a instituição da propriedade privada, a abolição do trabalho escravo, impôs uma moeda comum e iniciou coleta de impostos, para inserir o Afeganistão no sistema capitalista. Por fim, o rei criou uma constituição que garantia à população direitos básicos de cidadania, e os definia pela primeira vez como afegãos (Rubin, 1988).

Porém, seu afastamento do islamismo e aproximação com o ocidente gerou grande insatisfação entre a população, de modo que suas tentativas de reforma fracassaram. Em meio a tantas etnias e grupos tribais, o islamismo era o único elemento que traria coesão a sociedade afegã. Em 1929, o rei abdica do trono, e uma nova fase se inicia. A dinastia que passaria a governar o país traria um longo período de estabilidade, que se estenderia até a ocupação soviética 
(Rubin, 2002). Segundo Burke (2007), essa dinastia, cujo nome de família era Musahiban, enfatizava a importância do islamismo na política, pois sabiam que a religião era a única que garantiria apoio e unidade nacional entre a população. Durante os primeiros anos de poder, por meio da religião, foi possível articular as relações entre a sociedade tradicional afegã e o governo, reduzindo as tensões entre eles. Além disso, o sistema educacional cresceu a todo vapor: em 1961, havia 233.809 alunos matriculados em escolas públicas, enquanto que na década de 1930, havia em torno de 1350 (Rubin, 2002; Burke, 2007).

Entre 1946 e 1952, houve uma tentativa por parte dos Musahiban em se instaurar uma espécie de democracia, e um parlamento foi eleito. Foi uma oportunidade para que uma oposição florescesse, que vinha crescendo sobretudo a partir de movimentos estudantis. Porém, os governantes pretendiam continuar com atitudes reformistas e passaram a conter tais movimentos com repressão e violência. Isso gerou ainda mais insatisfação na população, que passou a exigir maior liberdade de expressão (Rubin, 1988). Em 1963, um novo rei dessa mesma família assume o poder, tenta articular as diferentes instâncias da sociedade para formular uma nova constituição, e convoca uma assembleia geral. No entanto, embora houvesse democracia parlamentar e certa abertura, nunca houve um processo de legalização de partidos políticos, o que geraria consequências (Rubin, 2002).

Como as elites agrárias e religiosas dominavam o parlamento, partidos clandestinos emergiram, liderados por intelectuais. Eram inspirados tanto pelas ideologias socialistas e comunistas, que ganhavam espaço no país após a aproximação com a União Soviética em plena Guerra Fria, quanto pelo islamismo político, o que culminaria em uma divisão política entre esses novos movimentos. Essa classe de intelectuais se formaria sobretudo na Universidade de Cabul (Rubin, 2002).

A principal organização de viés comunista, segundo Rubin (2002), era o Partido Democrático Afegão (PDPA), que era alinhado com Moscou. Porém, essa organização era dividida em duas facções: Parcham e Khalq. Essa organização recebia apoio total da União Soviética, que fornecia ajuda financeira e proteção política. Além disso, as facções possuíam amplo apoio do exército, o que permitiu com que ascendessem ao poder após o golpe contra a família real em 1978. Por outro lado, os partidos ligados ao islamismo político tinham como membros 
futuros líderes da insurgência contra a União Soviética, tais como Ahmad Shah Masood (que em seguida tornaria-se líder da Aliança do Norte) e Burhanuddin Rabbani, e o Hizb-i Islami, os islamitas (Rashid, 2008).

Diversos episódios e tentativas culminaram em um golpe militar em 1978, liderado por oficiais do exército inspirados pelo marxismo e levaram o PDPA ao controle do país, como, por exemplo, um primeiro golpe em 1973 (Rashid, 2008). No entanto, conforme explica Rubin (1989), a população afegã logo se revoltou com a brutalidade com a qual o novo governo comunista foi imposto, e com o radicalismo dos líderes do partido. Além disso, as duas facções, Parcham e Khalq, disputavam a liderança.

Em vista disso, a União Soviética enxergou a situação como uma ameaça, e visando estabilização e manutenção do comunismo no Afeganistão, invadiu o país em 1979. O resultado não foi exatamente o esperado: "The Soviets hoped to stabilize the PDPA regime but succeeded mainly in spreading revolt to previously unaffected regions" (Rubin, 1989, p. 152). E, dessa maneira, o Afeganistão foi tragado ao centro do palco da Guerra Fria (Rashid, 2009, p. 09), pois o conflito também atraiu atenção imediata dos Estados Unidos.

\section{1 .2 \\ Os Mujahedin durante a Ocupação Soviética}

A sucessão de golpes e as divisões internas que existiam dentro do partido PDPA criaram uma situação de instabilidade que chamou a atenção da União Soviética, que temia um provável colapso do partido comunista recém-chegado ao poder. Conforme já foi descrito, durante as décadas de 1960 e 1970, na evolução do sistema educacional no país e partidos políticos se desenvolveram. A Universidade de Cabul havia sido o berço comum para os líderes e fundadores de ambos os partidos, de modo que os integrantes eram ou estudantes, ou professores. No caso dos partidos seguidores do islamismo político ${ }^{2}$, eles se

2 Para o islamismo político, o Estado deveria ser absolutamente interligado com a religião, sem qualquer tipo de separação. O Islã teria seu próprio sistema econômico e político, e ao contrário do comunismo, o islamismo político prega a cooperação entre as diferentes classes sociais, e não a luta entre elas (RUBIN, 2002). Os islamistas afegãos almejavam chegar ao poder para implementar esse modelo a partir de uma reforma completa no sistema governamental. Conforme explicado por Harpviken (1997), a referência máxima para os islamitas radicais é o Estado em si, ou seja a instauração do islamismo político por completo em face dos desafios impostos pelo domínio das ideias e instituições ocidentais. 
caracterizavam pela oposição aos modelos ocidentais de desenvolvimento e de estado, e alegações de imperialismo ocidental (Rubin, 2002).

Em 1973, após o primeiro golpe de estado ensaiado pelos comunistas, os líderes islamitas fugiram para o Paquistão, evitando repressão por parte do novo governo que havia sido instaurado. O governo paquistanês, preocupado com a possível ascensão de qualquer movimento nacionalista tribal pashtun, ou seja, uma possível reorganização em princípios tribais, e temendo a eclosão de um conflito, prontamente ofereceu refúgio a esses líderes, que eram em sua maioria de origem pashtun, embora certos líderes fossem provenientes de outras etnias (Rubin, 2002). Em 1978, um novo golpe empreendido pelos comunistas ocorreu no Afeganistão, e os líderes islamitas refugiados no Paquistão formaram uma aliança cujas bases seriam instaladas na cidade de Peshawar. Essa aliança reunia sete partidos islâmicos, sendo que quatro deles eram de caráter fundamentalista ${ }^{3}$, segundo descrito por Rubin (2002) e Burke (2007). O governo paquistanês dava apoio financeiro e militar para todos os partidos. Durante o exílio, esses diferentes grupos planejavam maneiras de tomar o poder no Afeganistão, ainda que sem qualquer apoio ou mobilização conjunta da população, dado que estavam distantes da cena política afegã (Rubin, 2002).

A invasão soviética em 1979, no entanto, gerou um novo objetivo aos partidos: "The Soviet invasion transformed the fortunes of the Islamist and other Sunni leaders who had fled Afghanistan [...]. From heading small and largely ineffectual groups, they now acquired supporters, funds and weaponry." (Ewans, 2005, p. 111). A função deles seria a de fornecer assistência internacional e representatividade diplomática para a resistência que se configurava em solo afegão. Além disso, atuariam como intermediários entre o Serviço de Inteligência do Paquistão (ISI), responsável por centralizar os envios que chegavam dos Estados Unidos e da Arábia Saudita.

A instituição estatal afegã se desintegrou entre os anos de 1978 a 1979 , como reflexo dos dois golpes de estado. As áreas rurais, que tradicionalmente já tinham pouca presença do estado, ficaram às margens de qualquer atuação por

\footnotetext{
Por fundamentalismo, entende-se, conforme definido por Halliday (2005), mais do que apenas a interpretação literal de textos religiosos, a aplicação dos mesmos com objetivos políticos em um contexto contemporâneo, visando soluções para os problemas do mundo atual. Ou seja, problemas correntes devem ser resolvidos tendo como referência o que consta nos textos sagrados.
} 
parte do governo. Dessa maneira, a sociedade que habitava tais áreas passou a obedecer pequenas lideranças locais. Esses líderes, por sua vez, se aliaram à uma rede de jovens que iniciavam um forte movimento de resistência aos partidos comunistas e aos soviéticos. O número de adeptos crescia vertiginosamente, e se espalhava por diversas zonas rurais afegãs, o que eclodiu em um conflito armado contra o exército vermelho, a partir do momento da ocupação (Rubin, 2002).

Assim, o movimento de insurgência que florescia pelo Afeganistão era disperso e quase não havia centralização. Eram compostos por pequenos grupos de homens e um líder, e representavam os mais variados níveis da sociedade (Rais, 2008). Alguns se associavam aos partidos de Peshawar, enquanto outros se limitavam às lutas específicas de suas próprias regiões.

À medida em que a mobilização desses grupos se intensificava e ganhava dimensões de guerrilha, os insurgentes, ou mujahedin ${ }^{4}$, necessitavam de recursos e armamentos para se manterem. Dessa maneira, procuravam por aqueles que tivessem facilidade para obtê-los, e, para tal, iam ao Paquistão, onde muitos também se refugiavam ${ }^{5}$. A intensificação da pressão exercida pelo exército soviético forçava os insurgentes locais a buscar ajuda dos líderes que estavam exilados no Paquistão (Rubin, 2002).

O Paquistão, por sua vez, em vista do intenso fluxo de afegãos para os campos de refugiados em seu território, tomou como oportunidade e passou a garantir aos partidos islamitas acesso a esses campos, para que pudessem recrutar e treinar afegãos que estivessem dispostos a lutarem contra os soviéticos (Burke, 2007). Conforme apontado por Burke (2007), havia um desejo de que um grupo pró-Paquistão vencesse o conflito, e subsequentemente tomasse Cabul, o que seria interessante para o Paquistão. Assim, passaram a oferecer suporte ao conflito dos mujahedin. Além disso, Rupert (1989) acrescenta que o fluxo de mujahedin em solo paquistanês eram entendidos como uma grande ameaça à segurança e estabilidade da região, pois também ofereciam o risco de sofrerem possíveis retaliações soviéticas. Portanto, o exército paquistanês monitorou de perto todas as atividades dos grupos insurgentes.

4 A palavra mujahedin, em árabe, tem a mesma raiz que jihad, que significa esforço ou luta para defesa do Islã. Um mujaheed (plural mujahidin), portanto, é aquele que está engajado em uma jihad. (Rubin, 2002).

5 Rubin (2002) e Burke (2007) relatam que mais de 3 milhões de afegãos se refugiaram no Paquistão durante a década de 1980. 
Os grupos diretamente ligados aos islamitas eram treinados no Paquistão, enquanto que os grupos locais e tribais baseavam-se em lealdade ao líder, que fornecia comida aos integrantes, embora não tivessem estrutura para oferecer treinamentos (Rubin, 2002).

A luta ocorria com maior intensidade nas áreas rurais, o que levou a uma perda de controle do estado em relação a essas áreas. Desse modo, os mujahedin se consolidaram como poderosos nessas regiões, o que tornou a invasão soviética cada vez menos vantajosa e mais próxima de um fracasso, especialmente a partir do momento em que a ajuda fornecida pelos Estados Unidos se mostrava cada vez mais expressiva.

Os Estados Unidos se envolveram no conflito entre mujahedin afegãos e o Exército Vermelho desde seu início, em 1979, até a retirada das tropas soviéticas em 1989. O conflito, de acordo com Hartman (2002), resultou em mais de 1 milhão de mortos, e quase um quarto da população afegã se refugiou no Paquistão até o final de 1989. O autor descreve que, já em 1979, agentes da CIA já se encontravam secretamente com líderes mujahedin. Carter iniciou a ajuda com equipamentos médicos e medicamentos, e em seguida aprovou ajudas militares também.

O Paquistão foi utilizado pela CIA, que coordenava as ações americanas no Afeganistão, como chave para chegar nos mujahedin para fornecer ajuda, juntamente com a inteligência da própria agência paquistanesa (ISI). As quantias de dinheiro enviadas pelos EUA se mantinham sempre correspondendo aos valores enviados pela Arábia Saudita, que se aliou tanto aos americanos quanto ao Paquistão, visando apoiar os grupos islâmicos e encarando o conflito como uma jihad. O Paquistão e a Arábia Saudita, por sua vez, através dos sete partidos em Peshawar, enviavam os armamentos e outros suprimentos aos afegãos (Burke, 2007).

Segundo Thier (2006), a guerra no Afeganistão era custosa demais para a União Soviética, que se encontrava em crise econômica e política durante a década de 1980. Conforme apontado no parágrafo anterior, as tropas foram retiradas em 1989. As negociações para a retirada se iniciaram ainda em 1985, e se cristalizaram no Acordo de Genebra de 1988, norteado pelo princípio da nãointervenção. $\mathrm{O}$ acordo, no entanto, não se referia apenas as tropas soviéticas, mas 
se estendia também a pedir pelo fim da ajuda dos Estados Unidos aos mujahedin (Thier, 2006).

\subsection{3}

\section{A Guerra Civil no Afeganistão}

A resistência afegã após a invasão soviética logo se transformou em um conflito armado, que ocorreu de maneira descentralizada e fragmentada. A ajuda dos Estados Unidos e de outros países da comunidade islâmica contribuíram para a perpetuação da instabilidade no Afeganistão mesmo após a retirada das tropas da União Soviética, entre os anos de 1988 e 1989, uma vez que forneceram quantidades massivas de armamentos. Isso colaborou para o fomento do fluxo de armas que já existia entre as fronteiras do Afeganistão e Paquistão, que, por sua vez, eram distribuídas entre os mujahedin e a população (Rubin, 2002). Além disso, alimentaram as rivalidades entre os partidos afegãos instalados no Paquistão, que disputavam entre si o poder no Afeganistão após a queda da União Soviética. Outro grande problema nasce durante a invasão soviética, que continua a ameaçar a segurança da região até hoje: a produção do ópio, estimulada pelos mujahedin em busca de mais recursos para se manterem na guerra.

A falta de preparo e planejamento dos mujahedin para assumirem um novo governo no Afeganistão eclodiu em uma nova guerra civil na qual passaram a degladiaram entre si e disputarem territórios. O Afeganistão se desintegrou, e em seu território, passaram a existir outros menores praticamente independentes entre si. Alguns deles funcionavam como entidades autônomas, muitas vezes com governo e meios de comunicação próprios (Rubin, 2002).

Em Cabul, conforme relata Thier (2006, p. 473):

A mixture of mujahideen groups and government militia moved quickly to take different sectors of Kabul. Long-standing rivalries between these parties exacerbated by ideology, hunger for power, foreign designs and the limited attention of the international community - delivered a country already devastated by thirteen years of brutal conflict into the hands of radicals and opportunists. Fighting erupted in divided Kabul, destroying the capital, the country's remaining infra-structure, and the hopes of the Afghan people.

Thier (2006, p. 473) explica que, nesse momento, ou seja, início da década de 1990, a comunidade internacional estava mais preocupada com o que ocorria na Europa oriental, sobretudo na Iugoslávia, marginalizando o Afeganistão da 
política e das ajudas humanitárias. As sucessivas disputas pela liderança do Afeganistão levaram a ascensão do Talibã, que após uma série de pequenos conflitos, ocupa a maior parte do território e se legitima como poder.

\section{2}

\section{Talibã: Origens}

Sob o contexto da guerra civil que assolava o Afeganistão, a situação de Candahar, ao sul do Afeganistão, era particularmente crítica se comparada as outras províncias, que já se encontravam relativamente estabilizadas, sob lideranças autônomas, conforme já foi descrito.

Ainda enquanto sob ocupação soviética, os mujahedin que compunham a resistência da região consistiam em uma rede tribal dos pashtuns que tradicionalmente habitavam Candahar. Os chefes dos clãs, das tribos, bem como líderes religiosos criaram partidos, sendo que um deles, o Harakat, se aliou aos sete partidos de que estavam refugiados em Peshawar, no Paquistão. O partido era responsável por madrassas que se localizavam nos campos de refugiados na fronteira entre os dois países, nas proximidades entre Candahar e Quetta.

Nessas escolas, eram ensinadas tradições fundamentalistas islâmicas. Algumas eram mantidas pelos wahhabistas sauditas. Porém, conforme Rashid (1999, p. 26) relata, tais escolas também pregavam o deobandismo, que mais tarde, influenciará o Talibã. Essa interpretação seria uma vertente do islamismo sunita, que dentro do contexto da Índia Britânica, ascendeu devido a sua missão de se regenerar o Islã em face da colonização, de se resgatar as tradições de uma sociedade muçulmana.

Como não havia uma liderança centralizada em Candahar, ela era marginalizada e se transformou em uma região caótica (Rais, 2009). A cidade e seus entornos foram tomados por produtores e traficantes de drogas, máfias, e a população sofria com a violência. As mulheres sobretudo foram vítimas recorrentes de estupros. Os refugiados afegãos que estavam próximos a fronteira, embora ensaiassem um retorno, se assustavam com a situação e tornavam a se deslocar, ou mesmo retornavam aos campos (Rashid, 2010).

Foi precisamente no contexto desse fluxo frequente entre Quetta e Candahar, que um grupo de jovens estudantes pashtuns das madrassas, ao 
observar a situação caótica em sua cidade natal, deram início a uma mobilização, e se aliaram com ex-mujahedin, em vistas de se tentar restaurar a paz e a ordem na região. Mohammad Omar, professor de uma pequena madrassa e ex-combatente mujaheed, passou a liderar o movimento, angariando novos adeptos com assustadora rapidez - dado era o temor que os habitantes tinham com relação a violência crescente. Dessa maneira nascia e rapidamente ascendia o Talibã estudantes. Rais (2009) afirma que a grande proposta do Talibã era a de preencher o vácuo deixado pelo colapso do estado.

Sua expansão era promovida especialmente através de mensagens de que trariam de volta a paz, a justiça, e a segurança, e que portanto eram extremamente atraentes para a população. O movimento, segundo Rashid (2010) se propunha também a reforçar a aplicação das leis islâmicas (sharia), e defender a integridade do islamismo no Afeganistão. Burke (2006) e Rais (2009) acrescentam que o Talibã também tinha forte apelo nacionalista pashtun, cujas concepções de ordem e justiça eram referências ao rigoroso código de ética da etnia: o pashtunwali. Isso fez com que Talibã adquirisse credibilidade entre as tribos, o que, conforme discutido por Roy (1997), facilitou a sua expansão nos territórios tradicionalmente ocupados pelos pashtuns ('pashtun belt'), em sua maioria localizados ao sul do Afeganistão, galvanizando também a sensação de ressentimento em relação ao tratamento que havia sido dado aos pashtuns na nova configuração afegã póssoviética.

A despeito das relações do Talibã e da $\mathrm{Al}$ Qaeda, há uma série de controvérsias. O que se relata sobre Bin Laden, na obra de Burke (2007) é que ele era um jovem ele era um jovem voluntário saudita oriundo de família milionária, que enviava enormes quantias de dinheiro para a jihad entre mujahedin e exército vermelho. Bin Laden chegou ao Paquistão em torno de 1980, e em seus primeiros anos, residia em Peshawar e cuidava de combatentes feridos. Apenas anos depois ele teria se transferido para o campo de batalha. Após a saída da União Soviética, Bin Laden havia formado um grupo de jihadistas - al Qaeda -que visava combater as influências ocidentais no Islã. Foi durante a Guerra do Golfo, quando a Arábia Saudita permitiu aos EUA que posicionassem seu exército e força aérea em seu território, que Bin Laden passou a se pronunciar em relação aos Estados Unidos. 
Em 1991, Bin Laden pediu refúgio no Sudão, mas foi expulso pelo próprio governo, até que em 1996, ele retorna ao Afeganistão e se aproxima de Mulá Omar, o líder do Talibã. Em 1998, duas embaixadas dos Estados Unidos - no Quênia e na Tanzânia - sofrem atentados, que são atribuídos a Al Qaeda. Desse modo, Bin Laden, que já se pronunciava fortemente contra os Estados Unidos, atrai atenção internacional, e sofre retaliação americana, que bombardeia as supostas bases da Al Qaeda no Afeganistão; Washington começa, nesse momento, a pressionar o Talibã para que entreguen Bin Laden. O Talibã percebeu que o risco de se manter Bin Laden sob suas custas seria extremamente vantajoso: o terrorista havia se tornado uma moeda de barganha para qualquer tipo de negociação com os Estados Unidos. (Rashid, 2010; Thier, 2006).

Até que, dia 11 de setembro de 2001, as torres gêmeas em Nova Iorque são atingidas por aviões, atentado logo atribuído a Al Qaeda e Bin Laden. Thier (2006) relata resumidamente os antecedentes e controvérsias:

\begin{abstract}
The Taliban's chief opponent was Ahmad Shah Mahsood. On September, 9, 2001, al Qaeda operatives posing as journalists assassinated him. We cannot know for certain whether the timing of these events was coordinated, but there could have been little doubt that the events of September 11 would trigger a response against Al Qaeda in Afghanistan, and killing Mahsood may have been meant to undercut a military response. The result of these attacks was so spectacularly devastating, however, that the force, fury and rapidity of the reprisals were likely not anticipated, at least not by the Taliban: The United States officially commenced Operation Enduring Freedom on October 7, 2001, only twenty-six days later (Their, 2006, p. 476).
\end{abstract}

Os efeitos da entrada dos Estados Unidos no Afeganistão serão discutidos mais adiante nesse mesmo capítulo.

\title{
5.3
}

\section{Um Histórico da Proibição do Ópio}

O ópio é uma droga feita a partir da papoula, cujo uso data de mais de cinco milênios atrás, por diversas civilizações. É uma planta de cultivo simples, que não exige, por exemplo, um tipo de solo adequado. Sua irrigação também não requer estrutura específica, pois não carece de grandes quantidades de água. Além disso, a flor pode ser plantada em praticamente qualquer lugar. Ela é comum na Ásia e na Europa. O ópio, por sua vez, é o próprio suco extraído dos frutos da papoula em amadurecimento. Isso é importante, na medida em que, um dos motivos pelos 
quais o comércio ilegal de drogas é tão grande e lucrativo se deve ao fato de que, normalmente, as drogas são de fácil cultivo e não exigem técnicas muito sofisticadas em sua produção (Grillo, 2011; Silva, 2013). Segundo Grillo (2011, p. 21):

When this mush ${ }^{6}$ is eaten or smoked, it unleashes a miraculous effect: pain abruptly disappears. The consumer may have a gaping hole in the side of his head, but suddenly, all he can feel is numbness. The incredible speed with which it works has epic consequences. Opium is one of the most effective anesthetics known to man. It was even once sold in the United States under the label GOD'S OWN MEDICINE. But while curing agony, the mush also releases its infamous side effect: the consumer feels a sleepy euphoria.

O ópio tem, portanto, potente efeito analgésico e sonífero. Foi na antiguidade que ele consagrou-se por suas propriedades medicinais. Já durante o Renascimento, seu uso se difundiu por toda Europa, devido a, sobretudo, suas propriedades analgésicas. Silva (2013) relata que o consumo da droga era rápido, acessível, e eficaz, além do fato de que os riscos para saúde eram pouco conhecidos. Assim, o seu consumo era socialmente aceito, também para fins recreativos, e ainda não havia qualquer tipo de discriminação. Seus derivados, tal como a morfina, eram usados em larga escala durante o século XVIII e XIX, em especial durante guerras tais como a de Independência Americana, FrancoPrussiana, e Guerra Civil americana. Seu uso repetido, no entanto, conduz ao hábito, à dependência química, e, por fìm, a uma decadência física e intelectual. Por mais que, de fato, as pessoas se tornassem dependentes, a autora afirma que, por muito tempo, isso não foi visto como um problema. $\mathrm{O}$ ópio era tão aceito que era comercializado de forma livre, internacionalmente.

Foi apenas no século XIX, em especial na China, que o consumo excessivo e os altos índices de dependentes químicos chamaram atenção. Foi feito um decreto, pelo imperador, banindo a venda do ópio. No entanto, segundo Grillo (2011), essa proibição, a primeira do tipo no mundo, inaugurou também a primeira geração de traficantes, que eram os britânicos. Os mercadores ingleses (sobretudo a Companhia das Índias Orientais) compravam ópio na Índia e vendiam na China, ilegalmente. Isso, eventualmente, gerou conflitos. O exército chinês reagiu, a mando do imperador, criando tensões entre a China e o Reino Unido, culminando nas duas guerras do ópio: "When Qing ${ }^{7}$ soldiers stormed British ships, Queen

\footnotetext{
${ }^{6}$ O líquido, ou suco, extraído da papoula.

${ }^{7}$ Dinastia que reinava a China durante o fato descrito.
} 
Victoria's galleons showered the Chinese coast with cannon. If the East India Company was the first drug cartel, then the Royal Navy was the first band of violent cartel enforcers (Grillo, 2011, p. 23)". Por fim, foi conferido à Companhia das Índias Orientais o direito legítimo ao tráfico de ópio da Índia para a China. Silva (2013) argumenta que tal comercialização do ópio pelas potências europeias era parte de suas políticas mercantis coloniais na Ásia, sobretudo na China e na Índia. O ópio era considerado uma commodity.

O aumento do consumo recreativo do ópio no resto mundo foi atribuído, em lugares tais como os Estados Unidos, aos imigrantes chineses, que se estabeleciam e abriam casas para o uso recreativo do narcótico (Grillo, 2011). Os chamados opium dens se proliferavam em cidades como São Francisco, na Califórnia. Somase a isso também o crescente uso de outras drogas, que, tal como o ópio, também eram comercializadas livremente. A heroína, a cocaína, e cannabis ganhavam cada vez mais usuários. As duas últimas, em especial, eram produzidas na América Latina, e abasteciam o mercado americano. Nos Estados Unidos, religiosos protestantes passaram a enxergar isso como uma grande ameaça. Os Quakers iniciaram uma cruzada moral anti-ópio em 1874.

Um forte movimento moralista de lobby começou a tomar corpo, e, rapidamente, ganhar adeptos, sobretudo através do uso da mídia. Eram frequentes as associações feitas entre crimes e o uso de drogas, ou entre determinadas etnias e o uso de determinados narcóticos, em um movimento xenofóbico e repressor. Os jornais americanos, sempre de maneira sensacionalista, alegavam que os chineses usavam o ópio para estuprar mulheres brancas e que os negros do sul também cometiam crimes, tais como assassinatos, sob o forte efeito da cocaína (Grillo, 2011; Silva, 2013). Empresários americanos tinham medo que, com as drogas, a produtividade de seus empregados reduzisse (Andreas \& Nadelmann, 2006).

Foi então que a cruzada americana contra as drogas começou, alimentada por uma opinião pública já formada e preocupada com os efeitos, que segundo era difundido, devastadores que os narcóticos produziam. Em dezembro de 1914, foi assinado o primeiro ato com vistas a regulamentar a produção e o consumo do ópio e da cocaína, o Harrison Act. Conforme explicado por Grillo (2011, p. 25): "It was not totally prohibitionist, aiming to control rather than wipe out drugs. A certain amount of legal opiates would be needed for medicine as they are today. But the Harrison Act did create an immediate black-market trade in opium and 
cocaine". Ou seja, a primeira medida proibicionista (ainda que não por completo), inaugurou também o tráfico ilegal de narcóticos, através de um mercado negro.

No âmbito internacional, Silva (2013, p. 74) relata que os esforços que buscavam controle no comércio do ópio ainda se limitavam a movimentação entre China e Índia, até 1900. Porém,

\footnotetext{
Mas em 1908, quando o problema foi finalmente encaminhado - embora não resolvido - por meio de acordo entre a China e Grã-Bretanha para a redução do comércio do ópio, a situação no resto do mundo já era grave, sobretudo em virtude da descoberta da morfina, da heroína e de outros derivados, mais concentrados e fáceis de contrabandear pelas fronteiras. Começava-se a perceber que o problema já não afetava apenas o Oriente e que o comércio não podia ser policiado pelos países isoladamente, sendo necessária uma ação concertada (Silva, 2013, p. 74).
}

Por fim, foi nesse momento em que se reconheceu transnacionalidade do tráfico de drogas. Tendo isso em vista, em 1909, foi criada uma Comissão do Ópio pelos Estados Unidos, em conjunto com outras nações e, em seguida, foi realizada a Conferência de Xangai. Ela inauguraria a discussão do tema de maneira multilateral, visando discutir a temática e suas implicações, além de promover levantamentos da situação, em princípio do ópio, pelo mundo. Além disso, apesar de não ter imposto obrigações formais aos países signatários, a convenção foi responsável pelo estabelecimento de um arcabouço internacional, que mais tarde evoluiria para decisões tomadas em instituições como a Liga das Nações, e, mais tarde, a ONU. A próxima sessão tratará da questão dos narcóticos sobre o ponto de vista das novas guerras e das shadow economies, conforme proposto por Mark Duffield (2001).

\section{4}

\section{O Ópio e os Narcóticos como shadow economies}

Na presente subseção, apresentar-se-á as definições teóricas para entender a produção do ópio (e das drogas, de maneira geral) no Afeganistão como uma shadow economy, segundo proposto por Mark Duffield (2001), como parte de sua teoria sobre as novas guerras. Como sua tese se aplica, sobretudo, a países do sul, o México também é mencionado para dar suporte a argumentação.

Conforme já foi exposto em capítulo anterior, a crítica de Duffield (2001) se debruça sobre a recente incorporação da ideia de guerra dentro do discurso de 
desenvolvimento proferido pela governança global liberal. Tal discurso se pauta através da rearticulação dos países do Sul como uma ameaça. Tendo isso em vista, a literatura de Duffield (2011) permite um framework para entender o fenômeno das drogas, as quais são produzidas em larga escala em países considerados do Sul.

Duffield (2001) explica que a governança global liberal não se traduz em uma única instituição, mas sim, em redes e conexões que ligam diferentes organizações, grupos de interesse e formas de autoridade, em relação a regulamentações específicas. Ou seja, conforme foi apontado pelos autores especializados em drogas, Andreas e Nadelmann (2006), no que tange as drogas, existe um esforço em conjunto com as polícias de diferentes nações envolvidas nos regimes de proibição. Diga-se de passagem, a própria criação da Interpol foi um reflexo disso. Além disso, Duffield (2001) chama atenção também para o fato de que a governança global liberal é um "selective inclusive system”, ou seja, é altamente excludente, de modo que é, em sua essência, um projeto radical que "thrives on creating networks that bridge traditional boundaries, specialisms and disciplines (Duffield, 2001, p. 55)”. Portanto, por trás de tal projeto liberal, existe a noção de se controlar a população e determinar o que impõe riscos ou não.

Os diversos grupos sociais do chamado Sul buscam por vantagem política ou econômica através dos conflitos. Isso, segundo o autor, gera desenvolvimento e uma complexa transformação social. As shadow economies, como são chamadas, podem, portanto, ser entendidas como um sistema alternativo de poder e de lucro, pois novas formas de proteção e de autoridade emergem, tal como novas formas de se projetar poder. No entanto, a governança global liberal não aceita esse discurso e prefere não tratar tais fenômenos como processos transformação. É indispensável mencionar que, normalmente, as economias das "sombras", normalmente, correspondem a um pouco menos que a metade da atividade econômica total. Ele exemplifica através da economia das drogas, por exemplo, que movimenta mais de 500 bilhões de dólares por ano, e aponta a grande significância desses estados produtores.

As economias não formais podem ser facilmente traduzidas pelo narcotráfico. Tal como ele, elas quase sempre funcionam através de amplas redes de comércio que conectam vários níveis de produtores e de comerciantes de áreas remotas do planeta. Isso pode ser aplicado em vários locais que se consagraram 
pela produção das drogas, como, por exemplo, o Afeganistão (Rashid, 2010). A crescente expansão delas se deve, sobretudo, ao impacto de reformas liberais empreendidas ao redor do mundo através de ajustes econômicos ortodoxos. A década de 1980, também conhecida como a década perdida, ilustra com clareza essa proposição de Duffield. O México, por exemplo, também exemplo de shadow economy pelo tráfico de drogas, foi um dos países que mais sofreu durante essa década, em meio a uma profunda crise econômica.

Ainda durante a década de 1980, o Banco Mundial ainda tinha uma visão mais positiva a respeito dessas economias, mas nos anos 1990, foi conferido um tom negativo, associando segurança com desenvolvimento e evidenciando a necessidade de se estabilizar essas regiões. Por outro lado, outra característica dessas economias, conforme apontado por Duffield (2011), é que elas aprenderam a gerar empregos, a produzir bens manufaturados e a suprir alimentos à suas comunidades.

Essas economias extra-legais são definidas pelas suas naturezas assumidamente não liberais. Em primeiro lugar, elas têm como base estruturas estritamente locais, ou seja, são configuradas em clãs ou grupos étnicos, que imprimem suas próprias formas de legitimidade e de códigos regulatórios em suas shadow economies. Por se organizarem em estruturas essencialmente tradicionais, não são transparentes, e funcionam subvertendo os modelos de livre mercado e suas instituições. Ou seja, remetem ao modelo mercantilista. O Afeganistão, como maior produtor de ópio do mundo, também ilustra como a produção do narcótico ocorre em meio a determinadas etnias, organizadas de maneira clânica (Rashid, 2008). Tanto a produção quanto o comércio ocorrem de maneira subversiva, corrompendo funcionários do governo, funcionando através de redes que ligam tais funcionários, lavagem de dinheiro, contrabando, produção, e transporte, ultrapassando fronteiras nacionais.

Além disso, países como o Afeganistão, ou o México, são exemplos que suportam, também, a noção de instabilidade gerada pelo Sul, pelo subdesenvolvimento, ambos sob a influência dos Estados Unidos, que tenta imprimir sua autoridade através de políticas neoliberais. A construção de regimes de proibição e a tentativa de se aplicá-lo nessas regiões mostram-se, portanto, falha, pois não incorporam a existência das shadow economies como uma resposta a um modelo excludente, como uma adaptação e modo de sobrevivência 
encontrado por diferentes grupos sociais, que se organizaram de outras maneiras e construíram novos modelos econômicos e novas relações de poder.

\section{5}

\section{A Guerra Civil no Afeganistão e a Emergência da Produção do Ópio}

As origens de tal produção remetem a invasão soviética, em 1979, quando o Afeganistão entrou em permanente estado de guerra. Além de, historicamente, o país sofrer pela falta de recursos naturais, sobretudo devido às dificuldades apresentadas pelo próprio território, e pela dificuldade de se criar uma base de renda e de recursos para a nação, as décadas de guerra destruíram toda a infraestrutura que havia disponível no país. Além disso, as instituições estatais se encontravam gravemente enfraquecidas, o que resultou em um vácuo de poder, que foi preenchido por senhores de guerra, milícias, traficantes de drogas, e contrabandistas (Rashid, 2008). A população foi a maior afetada: o Afeganistão se encontrava devastado, levando boa parte das pessoas a se refugiarem nos países vizinhos, buscando fugir da pobreza e da baixa qualidade e expectativa de vida que o país oferecia.

A economia, consequentemente, entrou em colapso: qualquer tipo de produção ou cultivo havia sido destruído pelo Exército Vermelho, e boa parte das precárias estruturas econômicas foi reorientada para a manutenção da guerra (Rubin, 2002). Candahar, berço do Talibã, por exemplo, por ser um oásis em meio a desertos e montanhas, tinha muitas terras férteis, e se consagrou nos séculos antecessores por ser uma região rica em cultivo de frutas. No entanto, durante a invasão soviéticaas fazendas de Candahar também foram vítimas da destruição e bombardeios por parte do Exército Vermelho (Rashid, 2010).

Desse modo, a população estava disposta a encontrar meios de subsistência que gerassem lucro suficiente para sobreviver e que exigissem pouco investimento ou mão de obra. Havia muita demanda pelo ópio no mundo, graças a uma diminuição, durante a década de 80 , do cultivo da papoula na região conhecida por Triângulo Dourado (que compreendia a região do Mianmar), após a aplicação de uma série de políticas de erradicação (Peters, 2009).

Portanto, não só a população havia encontrado no ópio uma fonte de renda, quanto os mujahedin, durante a guerra contra a ocupação da União Soviética, 
enxergaram nas drogas uma excelente oportunidade para se abastecerem, a partir dos lucros que tanto o tráfico quanto a produção geravam. A cultura do ópio permitiu com que muitos deles se tornassem poderosos senhores de guerra, e, com isso, após o colapso da União Soviética, transformaram-se em líderes autônomos em determinadas regiões e províncias afegãs (Rubin, 2002).

Candahar, por sua vez, ainda se encontrava em situação análoga ao estado de natureza hobbesiano. Os fazendeiros de Candahar, em busca de novas fontes de renda, abraçaram a oportunidade da produção do ópio, levando em conta o rápido retorno que a papoula geraria e a simplicidade do cultivo, que exigia poucos trabalhadores e pouco investimento. A produção foi impulsionada pelo retorno dos refugiados, em especial os que estavam na fronteira com o Paquistão, nas proximidades de Candahar, em 1990, que passaram a cultivar a papoula como modo de vida (Rashid, 2010). Não demorou para que o sul do Afeganistão se consolidasse como o maior produtor de ópio do país.

\section{6 \\ Economia do Ópio durante o período Talibã}

Ahmed Rashid (2010) é jornalista e autor de uma das obras mais completas sobre o Talibã. Nessa obra, ele dedica um capítulo inteiro sobre a produção do ópio no Afeganistão durante os anos em que a maioria do território estava sob controle do movimento. O jornalista coletou relatos em campo de fazendeiros e produtores, e os alia a dados compilados pelo UNODC. Seu capítulo é referência como introdução ao assunto, no que se refere a produção durante o período Talibã.

Uma das indagações de Rashid (2010) se refere aos motivos pelos quais o Talibã permite e estimula a produção de ópio. $\mathrm{O}$ autor aponta algumas hipóteses e alternativas com base em sua pesquisa e viagem. Uma de suas primeiras hipóteses seria de que o Talibã garantia a segurança dos fazendeiros de papoula nas regiões rurais do Afeganistão, e isso compunha boa parte de sua base de seguidores (Rashid, 2010).

Embora o islamismo proíba o consumo e a produção de narcóticos, o Talibã concedeu uma espécie de permissão aos fazendeiros de papoula, e estimulava a produção do ópio através de tais benefícios. A época das entrevistas, 
no entanto, o consumo ainda era relativamente baixo se comparado ao que ocorre atualmente (UNODC, 2012). Pois supostamente, muçulmanos não consumiam as drogas, que, no Afeganistão, seria consumidas por kafires ${ }^{8}$ e por ocidentais.

Outros autores, como Gretchen Peters (2009), fornecem outras hipóteses acerca do Talibã e sua relação com o ópio. Segundo ela, foram encontrados relatos que afirmavam que, de fato, o Talibã, a princípio, era bem intencionado, muito embora seus métodos remetessem a Idade Média. Porém, a despeito do ópio, houve uma intenção inicial de abolir a produção e comércio, até que notaram a necessidade política e econômica de se manter. Tanto ela quanto Rashid (2010) concordam que o Talibã, desde o início, pouco funcionava como grupo religioso: estava mais próximo de grupos criminosos, sobretudo no que diz respeito ao financiamento do movimento. Isso se intensificou no Talibã ressurgente pós suposta derrota dos Estados Unidos entre 2001 e 2002 (Peters, 2009, Rashid, 2010).

Enquanto o Talibã sofria sanções econômicas da comunidade internacional entre 1999 e 2001, não falta fundos ou renda para manutenção do movimento; continuavam a ter fornecimento ativo de armas. Embora houvesse uma crença entre a comunidade de que o Paquistão fornecesse ajuda ao Talibã, era evidente que a economia do ópio estava gerando muito lucro e muita vantagem ao grupo. Porém, Peters (2009) faz menção ao fato de que os Estados Unidos ainda pouco se preocupavam com a dimensão da situação, do quanto o Talibã se sustentava nessa economia, e de que talvez ela fosse uma das raízes do problema. Enquanto isso, a mídia destacava outros pontos aterrorizantes do movimento, da violência e segregação em relação as mulheres, proibição de música e qualquer tipo de entretenimento, e a interpretação radical das leis islâmicas que o Talibã parecia seguir.

Rashid (2010) chama atenção ao fato de que produção em larga escala foi utilizada pelo movimento como moeda de barganha em troca de reconhecimento e legitimidade frente a comunidade internacional. Rashid (2010) ressalta a singularidade de tal tentativa de negociação:

Governor Mohammad Hassan justifies this unique policy with another twist. "Drugs are evil and we would like to substitute poppies with another cash crop, but it's not possible because we do not have international recognition". Over the

\footnotetext{
${ }^{8}$ Kafires seriam os infiéis no mundo islâmico.
} 
next two years, Mullah Omar was to periodically offer US and the UN an end to poppy cultivation, if the Taliban were given international recognition - the first time a movement controlling 90 percent of a country had offered the international community such an option (Rashid, 2010, p. 118).

Em vista da lucratividade que estava sendo gerada através da produção da droga, o Talibã formalizou a atividade para que pudesse aumentar a renda ainda mais. Assim, começaram a recolher impostos através de uma taxa chamada de zakat, que era aplicada aos traficantes. Muito embora o zakat seja, na realidade, um tipo de imposto estabelecido pelas leis islâmicas coletado para ser revertido aos pobres (Rashid, 2010). No entanto, conforme explicitado no relato de Rashid (2010), havia uma produção crescente de haxixe no Afeganistão, que não foi permitida, e em seguida, interrompida com sucesso pelo Talibã.

Boa parte da base de recursos que o Talibã formou eram direcionadas para o financiamento e treinamento de soldados, e para compra de armas e jipes. Tais recursos advinham ${ }^{9}$, em sua maioria, do contrabando e do cultivo do ópio em regiões sob domínio do movimento, além da parcela de armamentos e infraestrutura que eram fornecidos pelo Paquistão e Arábia Saudita (Rashid, 2010). Conforme descreve Rashid (2010, p. 119):

\begin{abstract}
Between 1992 and 1995 Afghanistan had produced a steady 2200-2400 metric tonnes of opium every year, rivalling Burma as the world's largest producer of raw opium. In 1996 Afghanistan produced 2.250 metric tonnes. Officials of the United Nations Drugs Control Programme (UNDCP) said that in 1996 Kandahar province alone produced 120 metric tonnes of opium harvested from 3.160 hectares of poppy fields, a staggering increase from 1995, when only 79 metric tonnes was produced from 2.460 hectares. Then, in 1997 , as Taliban control extended to Kabul and further north, Afghanistan's opium production rose by a staggering $25 \%$ to 28.000 metric tonnes. The tens of thousands Pashtun refugees arriving in Taliban-controlled areas from Pakistan were farming their lands for the easiest and most lucrative cash crop available.
\end{abstract}

Em 1999, a produção já era 3 vezes maior que a do mundo inteiro, e ela acontecia inteiramente em terras do Talibã (Peters, 2009). O ópio havia permitido também com que o Talibã conquistasse boa parte de seus seguidores. Depoimentos coletados por Ahmed Rashid (2002, p. 117) em suas viagens pelo Afeganistão, comprovam a importância que o cultivo da papoula havia gerado na vida das populações sob o domínio do Talibã, que para garantir seu lucro, permitia

9 Os autores apresentam estimativas, uma vez que, em primeiro lugar, o Talibã não mantinha nenhum arquivo escrito que relatasse ou calculasse o quanto arrecadavam através das drogas. Além disso, quando se refere a economias informais, os dados normalmente são estimativas, inclusive os do UNODC. 
com que os produtores tivessem segurança para prosseguir com a produção:

'We cannot be more grateful to the Taliban', said Wali Jan, a toothless, elderly farmer as he weeded his fields. 'The Taliban has brought us security so we can grow our poppy in peace. I need the poppy crop to support my 14 family members,' he added. The Taliban objective of re-establishing peace and security in the countryside has proved to be an immense boom to opium farming.

Nesse sentido, a concentração da produção se dava regionalmente, de modo que quase $95 \%$ era concentrada em apenas 5 províncias (de um total de 32), localizadas ao sul e ao leste do Afeganistão (Peters, 2009). O controle delas se dava em grande parte por líderes locais, sendo que $85 \%$ eram de etnia pashtun, que tradicionalmente ocupavam essas regiões no Afeganistão (Rashid, 2010).

No ano 2000, a área cultivada somada ao tamanho dos estoques eram tais que os preços do ópio despencaram. Pressionado pela ONU e sob o efeito de sanções econômicas impostas pela troca de Bin Laden, e pelo fim do escoamento das drogas que perpetrava guerras civis pela Ásia Central, o Talibã buscava reconhecimento internacional para que as sanções tivessem um fim. Mulá Omar decidiu, portanto, proibir apenas produção (e não sua comercialização) da papoula em todo o território dominado pelo Talibã. Em 2001, a produção já havia caído 95\%, e, sob ameaça de desabastecimento, os preços explodiram, e as vendas garantiram enormes lucros para o Talibã (Peters, 2009). Em outubro, devido a intervenção dos Estados Unidos, a estrutura central do Talibã foi abalada e sua liderança fugiu para o Paquistão, e as proibições referentes a produção foram suspensas. Os efeitos da intervenção dos Estados Unidos na produção e tráfico da droga serão explorados na próxima subseção.

\section{7}

\section{A Produção do Ópio pós 11/9}

O United Nations Office for Drugs and Crime (UNODC) (2014) estima que o país seja o maior produtor de ópio e heroína do mundo, cerca de $80 \%$ da produção mundial. A produção de haxixe também tem crescido consideravelmente. Além disso, conforme demonstrado por pesquisas do mesmo organismo, o crescimento mais significativo de tais produções se deram após a 
entrada dos Estados Unidos e das forças da OTAN no país, conforme pode ser observado na figura reproduzida.

O UNODC (2014) também estima que a área total que cultivo da papoula para o ópio seja de 224.000 hectares, o que significa que houve um aumento em relação ao ano passado, de em torno de 7\%. Na pesquisa do UNODC (2014) também foi comprovado que a maioria da produção, quase $90 \%$, se concentra nas províncias do sul do Afeganistão.

Figura 1. Cultivo da papoula por hectares no Afeganistão. 1994$2014^{10}$.

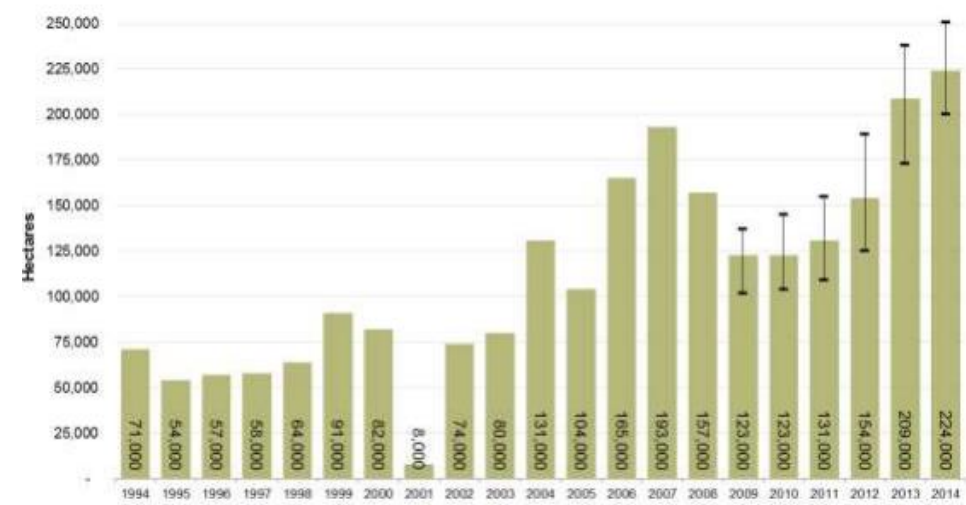

Figura 2. Produção de ópio em toneladas no Afeganistão. 1997-2012

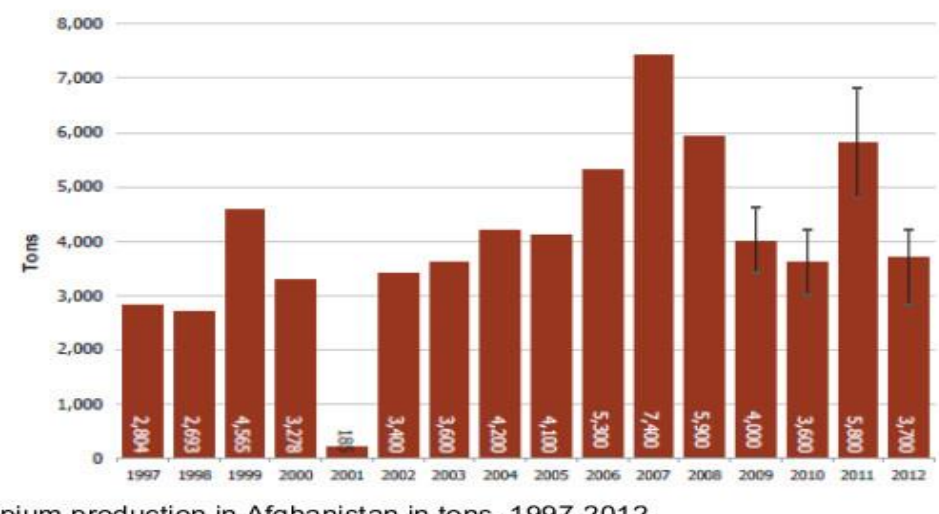

Opium production in Afghanistan in tons, 1997-2012 Source: UNODC's Afghanistan Opium Survey 2012

10 ESCRITÓRIO das Nações Unidas para Drogas e Crimes, 2014. Disponível em: http://www.unodc.org/documents/cropmonitoring/Afghanistan/Afghan-opium-survey-2014.pdf 
Em 2009, o UNODC (2009a) realizou pesquisas acerca do uso da droga também. O órgão estimou que anualmente, ocorrem mais de 100.000 mortes no mundo todo decorrentes do uso de opiáceos que vêm do Afeganistão; outro fato interessante é de que, apenas na Rússia, o número de usuários de heroína afegã se multiplicou por 10 na última década. O Irã, que também recebe essa mesma droga, contabiliza mais de 1 milhão de usuários.

Outra pesquisa foi feita pelo mesmo órgão, mas voltada para o uso dos opiáceos no próprio Afeganistão. As descobertas também foram arrebatadoras.

Illicit drug use has increased across the country, dramatically so for opium, heroin and other opiates. In four years, the number of regular opium users in Afghanista $\mathrm{n}$ grew from 150,000 to approximately 230,000 - a jump of 53 per cent. The numbe rs are even more alarming for heroin. In 2005, the estimate of regular heroin users in

the country was 50,000, compared to approximately 120,000 users in 2009 , a leap of 140 per cent. Overall, the annual prevalence of regular opiate use is estimated to be 2.7 per cent of the adult population1 (between 290,000 and 360,000 persons) (UNODC, 2009b, p. 05).

Estima-se que existem por volta de 1 milhão de usuários de droga adultos no Afeganistão, o que corresponde a $8 \%$ da faixa de população entre as idades de 15 e 64 anos (UNODC, 2009b, p. 05).

Assim, o que se entende por essas estatísticas é de que não só boa parte da população adotou o cultivo como estratégia de sobrevivência, mas também isso tem se tornado um agravante em termos de problema de saúde pública: o número de viciados afegãos na droga tem crescido exponencialmente. Outro relatório estimou que o Afeganistão consome 4\% do ópio produzido (Unodc, 2014b).

A despeito da produção do ópio durante a ressurgência do Talibã, Peters (2009) argumenta que a produção do ópio foi uma das grandes fontes de renda que permitiram o retorno do movimento. Foi principalmente durante os anos sob intervenção ocidental que a produção realmente deslanchou, conforme já foi demonstrado através dos dados da ONU e de seus gráficos.

A produção ocorreu de maneira intensa principalmente na região sul do Afeganistão. As razões são: as condições de segurança eram muito baixas - foi o último lugar em que a ISAF chegou, sob coordenação britânica através das PRTs, logo, havia pouca governança, instituições, e infra-estrutura, e, por fim era a região cuja fronteira com o Paquistão era a mais porosa, o que permitiu com que o 
movimento retornasse através de tais províncias: Farah, Helmand, Kandahar, Nimroz, Uruzgan, e Zabul, de acordo com Peters (2009). Embora não existam muitas informações precisas, Peters (2009) relata que, além de cobrar impostos e taxas da produção, existem indícios de que há grande participação no tráfico também. Ela afirma que grande parte da droga, ópio ou heroína que saem do Afeganistão e partem para Irã ou Paquistão teriam passado pelo Talibã de alguma maneira. Peters (2009) aponta também que estima-se que, no ano de 2009, mais de cem milhões de dólares foram arrecadados pelo Talibã através do comércio do ópio. Já Goodhand (2008, p. 409) acrescenta que, após o início do processo de reconstrução do Afeganistão, a produção e venda do ópio foram criminalizados, o que implicou em um aumento do preço da droga devido ao risco de sua venda e transporte. Além disso, os produtores passaram a necessitar de proteção e modos para produzir ilegalmente, o que contribuiu também para o retorno do Talibã.

Por fim, Goodhand (2008) explica que não há integração da produção dos opiáceos no Afeganistão. Ele crê que o funcionamento se dá em forma de redes interconectadas, mas que não existe um cartel ou hierarquia organizados que controlem a produção e venda das drogas, tal como ocorre no México, por exemplo. Existem, no entanto, diversos pequenos fazendeiros produtores, e diversos grupos insurgentes (não apenas o Talibã), que trabalham em conjunto com outras redes que compõem a estrutura da produção e do tráfico.

\section{8}

\section{A Intervenção da OTAN e as Políticas de Combate ao Ópio Adotadas}

Após a intervenção militar dos Estados Unidos no Afeganistão, a produção alcançou números sem precedentes, e o país se tornou o maior produtor de ópio do mundo:

The US intervention and subsequent peacekeeping and stabilization efforts by the international actors - Operation Enduring Freedom, NATO's (the North Atlantic Treaty Organization) International Security Assistance Force,and the UN Assistance Mission in Afghanistan (UNAMA) - nonetheless transformed the organization and magnitude of these illicit economies (Felbab Brown, 2009, p. 100).

Em primeiro lugar, essa sessão se voltará a explicar, de maneira breve, qual o objetivo de cada missão que foi enviada ao Afeganistão. Em seguida, será 
explicada qual a ordem cronológica das medidas voltadas ao combate ao ópio durante o período da intervenção, e como refletiram mudanças nos mandatos.

A Operation Enduring Freedom foi enviada dia 7 de outubro de 2001 e foi a primeira campanha militar no Afeganistão em resposta aos atentados. Ela foi iniciada pelos Estados Unidos, que enviaram suas forças aéreas para bombardear alvos estratégicos do Talibã e da Al Qaeda, como bases militares, aéreas e campos de treinamento. Em seguida, a operação formou uma parceria com a Aliança do Norte, para quem forneceu financiamento, armas, equipamentos de telecomunicação (Thier, 2006). Assim, segundo Felbab Brown (2009, p. 105), a princípio o objetivo da missão era "to degrade al Qaeda capabilities and institute regime change in Afghanistan". Ela ressalta que conter a produção do ópio já não era uma das funções da missão. Um dos motivos apontados pela autora era de que os Estados Unidos precisavam de determinados contatos chave de inteligência para a operação, que estavam diretamente ligados a produção e tráfico da droga. Essa se manteve a postura dos Estados Unidos até 2003. Conforme acrescenta Goodhand (2008), as prioridades da missão era essencialmente combater o terrorismo, conforme constava na retórica da Guerra ao Terror.

Em cinco semanas, o Talibã foi derrotado pela Aliança do Norte e pelos bombardeios aéreos das forças americanas. No entanto, toda a liderança do Talibã, bem como da Al Qaeda fugiram durante esse período, o que tornou a operação um grande fracasso. A grande maioria se refugiou nas porosas fronteiras com o Paquistão, ou nas cadeias de montanha, como foi o caso de Bin Laden. Segundo Thier (2006), culpava-se o fracasso das operações pelo fato de que ocorreram sobretudo via ataques aéreos, e não terrestres.

Em dezembro de 2001, o acordo de Bonn foi assinado. O acordo estabeleceu as novas bases para se compor um novo sistema político para o Afeganistão, além de constarem todas as decisões a respeito da entrada das forças internacionais no país sob o contexto da Guerra ao Terror. Foi endossado pelo Conselho de Segurança e sugeria processos ambiciosos: pacificação e reconstrução, fora a transição via governo interino. Segundo Thier (2006, p. 482):

The state-building process would be the engine for reconstruction, for the formation of long-term security arrangements, and for a return to national unity. The peace process would maintain order among factions, allowing them to lessen their enmity while acknowledging, it implicitly, their de facto control of the country. The Bonn Agreement envisioned that the state and political institutions, 
such as a constitutional process and elections, would slowly draw sovereign authority back to the government and people, and away from the rule of the gun.

Em novembro de 2002, os Estados Unidos lançam as PRTs no Afeganistão: Provincial Reconstruction Teams. Segundo Jacobson (2005, p. 11), tal projeto foi concebido para preparar a transição entre combate e reconstrução focada na estabilização : "The overall idea was to use small joint civil-military teams to expand the legitimacy of the central government to the regions and enhance security by supporting security sector reform and facilitating the reconstruction process". Quando foi publicado um relatório de princípios a serem utilizados nas PRTs, em 2003, foram estabelecidas três áreas de atividades basilares dos times, que seriam reconstrução, segurança e apoio ao governo nacional afegão.

In addition, they also stated that the PRTs would engage in relief operations in certain circumstances. The United States invited other countries to establish similar teams and by October 2004, a total of 19 PRTs had been established with more being planned by the United States and NATO.13 14 PRTs were managed by the US-led Combined Forces Command Afghanistan (CFC-A) conducting $\mathrm{OEF}$, and the remaining five by ISAF. The PRTs have now become the principal tool employed by NATO to expand ISAF beyond Kabul, and the alliance is planning to establish additional PRTs in Northwest Afghanistan in 2005.

Em geral, os times que compõem as PRTs são, em sua maioria, de militares (embora também constem civis), refletindo o que foi descrito no capítulo três sobre militarização do humanitarismo em operações de estabilização. Havia também envolvimento do governo afegão para coordenação das atividades das PRTs.

A despeito da militarização do humanitarismo, fenômeno característico tanto da ocupação no Afeganistão quanto no Iraque, Jacobson (2005, p. 12) ressalta que embora as missões sejam compostas tanto por civis quanto militares,

The PRTs are configured as joint civil-military teams in order to improve civil military coordination and enhance the quality of the military "hearts and minds" campaigns by drawing on civilian expertise and facilitating the dispersal of government funds for relief and reconstruction projects and security sector reform. The degree of real civil-military integration varies greatly, however.

Ou seja, a maneira pela qual as PRTs foram concebidas refletem a mentalidade "hearts and minds" por trás de tais missões de estabilização, em que o componente humanitário está, na realidade, subordinado por trás das intenções 
de estabilização e de segurança - em última instância, preocupadas com os estados mandantes, e não receptores, como os discursos a serem analisados nos comprovarão. Essa guinada - indicador também de mudança no objeto referente, destaque para o estado mandante - foi característica do pós 11 de setembro, conforme já foi apontado.

Já a UNAMA foi a missão enviada pela ONU para coordenar e monitorar a implementação do acordo firmado em Bonn. Seu objetivo era de integrar todos os elementos da ONU presentes no Afeganistão em uma mesma missão, e administrar a reconstrução (Thier, 2006).

Em 2002, durante encontro do G8, foi contemplado ao Reino Unido a responsabilidade de se administrar a questão do ópio, no processo de reconstrução do Afeganistão. A primeira medida que viria a ser tomada pelo Reino Unido seria a de erradicação das plantações de papoula, e pagariam determinada quantia em dinheiro aos fazendeiros, em troca (Felbab Brown, 2009). Porém, programas de erradicação nem sempre geram os resultados esperados.

From the outset, the policy was plagued by numerous problems: local Afghan strongmen collected the money and did not distribute the compensation to the farmers; many farmers did not eradicate their poppy and those who did were frequently left unpaid. Even farmers who received the aid were compensated at a level significantly below their income from opium, and indeed, below the level necessary for subsistence and for repaying outstanding debts.25 Moreover, the money allocated to the policy rapidly ran out. And in a prime instance of moral hazard, the north of the country started growing much more poppy simply to collect greater compensation fees (Felbab Brown, 2009, p. 106).

Assim, conforme observado pela autora, a estratégia não era nem organizada adequadamente. Não só deixavam, muitas vezes, de pagar os fazendeiros que acabavam com suas produções, como também havia pouca aceitação para essa população, que muitas vezes se rebelava, e, quando recebiam alguma quantia de dinheiro, não compensava em relação ao que lucravam com a produção da papoula.

A ISAF foi constituída como uma força multinacional, conforme estabelecido no acordo de Bonn em dezembro de 2001. A princípio, a liderança coube ao Reino Unido, que ficou responsável pelo processo de organizá-la e comandá-la nos primeiros três meses de operação (Saikal, 2006) Conforme apontado por Thier (2006), a ISAF foi a única missão enviada ao Afeganistão com 
um mandato de manutenção de paz e segurança explícitos. O mandato da ISAF permitia com que todas as forças necessárias fossem utilizadas para cumpri-lo.

Foi apenas em 2003 que a OTAN assumiu o controle da operação, com vistas de expandi-la, transformando o Afeganistão em uma nova prioridade para a organização, de acordo com Thier (2006). A primeira PRT oficialmente coordenada pela OTAN no Afeganistão foi estabelecida em 2003, pela Alemanha, em Kunduz, segundo Thier (2006, p. 545).

Em 2003, quando a OTAN assimiu, o modelo anterior de combate ao ópio havia sido abandonado, e houve uma nova tentativa foi implementada em 2004: as interdições, cujo foco seria nos traficantes e nos laboratórios de processamento. Ou seja, interditariam os fluxos de tráfico e tais laboratórios, de onde a droga saía pronta para o consumo.

A PRT britânica era responsável pela província de maiores índices de produção de ópio, e sempre passou por dificuldades em suas estratégias de combate. Foi apenas nesse ano, 2004, em que o Reino Unido passou a ter apoio dos Estados Unidos nessas políticas, embora ainda houvesse relutância por parte dos americanos, que temiam ficar sem contatos chave para obter informações sobre o Talibã, já que a grande maioria dos fazendeiros eram protegidos pela organização.

A despeito da interdição propriamente dita, Felbab Brown (2009, p. 107) enfatiza seus principais problemas: em primeiro lugar, houve corrupção em larga escala. Os afegãos envolvidos na política e que estavam entremeados na produção do ópio usaram as interdições como oportunidade para eliminar a concorrência. Além disso, grande parte das interdições que obtiveram sucesso foram apenas com pequenos produtores, garantindo vantagem aos grandes, pois tinham influência política. Outra grande consequência negativa foi que o Talibã se reintegrou na produção dos opiáceos oferecendo proteção a quem corria o risco de sofrer interdição (Felbab Brown, 2009).

Enquanto isso, a produção continuava crescendo de maneira alarmante. Em vista disso os Estados Unidos coordenaram duas campanhas de erradicação entre 2004 e 2005. Porém, em regiões como Candahar, que dependem largamente da produção, o resultado foi uma grande revolta da população, com direito a protestos e greves, conforme relatado por Felbab Brown (2009). Tentativas de cultivos alternativos também foram insuficientes, ou se comprovaram um 
fracasso, pois a rentabilidade não se comparava a do ópio. Outras tentativas de erradicação foram promovidas nos anos que se seguiram. No entanto, além da população não aceitar, a erradicação também sofreu interferência da corrupção. Para além disso, nos poucos cultivos em que havia sucesso, a erradicação não se sustentava e retornavam ao plantio da papoula rapidamente.

Apenas em uma província, Nangarhar, houve sucesso através de erradicação, em 2008:

This was achieved through the physical eradication of poppy, the co-option of tribal elites by the provincial authorities with promises of alternative livelihoods and personal payoffs, and threats that NATO would bomb the houses of those who failed to comply (Felbab Brown, 2009, p. 108).

Felbab Brown (2009, p. 109), no que tange as outras regiões, aponta para a lentidão na implementação de cultivos alternativos e a falta de buscar resolver os problemas na raiz da estrutura da produção do ópio no Afeganistão. Além disso, essas medidas fracassaram em prejudicar a renda do Talibã, e o fortaleceu na medida em que fazendeiros pediam proteção ao movimento para que não sofressem erradicação, por exemplo. Por fim, ela conclui que:

Counter-narcotics efforts are indeed a key component of stabilization and reconstruction in Afghanistan and in any country where licit livelihoods have been decimated and an illicit narcotics economy thrives and intermingles with violent conflict. However, premature and inappropriate efforts against such an illicit economy - be it in the production and trade of drugs or other commodities - greatly complicate counter-terrorism, counter-insurgency, and stabilization objectives, and hence ultimately also jeopardize economic reconstruction and political consolidation (Felbab Brown, 2009, p. 205)

Assim, Felbab Brown, através de seu detalhado estudo, nos confirma como não houve qualquer coerência ou planejamento adequado quanto as políticas de combate ao ópio no Afeganistão. O uso de estratégias comprovadamente falhas em outras operações americanas (como México e Colômbia) foram reproduzidas no Afeganistão, novamente gerando fracassos. As únicas tentativas adotadas tanto pelo Reino Unido quanto pelos Estados Unidos se resumiram a interdição, erradicação, ou, ainda, a promoção de cultivos alternativos. Nenhuma delas teve aceitação da população afegã pois não se mostraram vantajosas ou benéficas, tampouco permitiram com que atingissem o bem-estar no sentido apresentado por Pugh. 
O crescimento da produção e falha nas estratégias quanto a erradicação e combate nos comprovam como as drogas no Afeganistão funcionam como shadow economies no sentido de Duffield e de Pugh. O projeto da paz liberal é radical e busca uma transformação completa em regiões do sul que apresentam instabilidades e ameaças à segurança internacional. No entanto, a implementação de um modelo liberal se dá de maneira imposta, em que não são analisadas alternativas em que possam se adequar a cultura e necessidades locais. Uma economia de mercado e bem-estar que mire no aumento do poder de consumo, no Afeganistão, não levou benefício a todos os indivíduos. Os ganhos não foram iguais para todos, como o livre comércio e a economia de mercado prometem. Tampouco houve sensação de bem-estar. A produção do ópio se provou mais lucrativa do que qualquer outra alternativa apresentada, mas a missão da OTAN optou por não enxergar as reais necessidades do indivíduo afegão e se focou em suas estratégias apenas para estabilização da segurança - que está intimamente ligada com a produção da droga, na medida em que ela financia os movimentos insurgentes. 


\section{O Conflito no Afeganistão e seu(s) Objeto(s) de Referência}

O capítulo anterior se propôs a estabelecer e articular as bases sobre a concorrência entre objetos de referência por trás da paz liberal e das missões de peacebuilding. A discussão avançou para, inclusive, abordar a possibilidade de mudança de inclinação no objeto de referência a partir dos atentados do dia 11 de setembro e as missões de estabilização, como é o caso do Afeganistão, que o sucederam.

Subentende-se que a paz liberal tem dois objetos de referência, que concorrem entre si: o estado mandante, no caso, os Estados Unidos, ou o ocidente, representados pela OTAN, e os indivíduos do estado receptor. O estudo de caso se propõe a ilustrar os questionamentos propostos pelo presente trabalho através do exemplo do Afeganistão, observando especificamente a missão da OTAN, e de que modo a marginalização da questão do ópio representa um desequilíbrio entre esses dois objetos, voltados a segurança do ocidente.

Investigamos se a missão tem sucesso em prover o bem estar (um dos principais elementos do liberalismo e da paz liberal) para a população afegã, ou se fracassa. Assim, o que se pretende argumentar através da crescente economia do ópio no Afeganistão é que a missão não consegue prover bem-estar para a população, de modo que ela é buscada através das economias ilícitas - no caso, a produção e comercialização de narcóticos, como alternativa para tal.

O principal objetivo dos Estados Unidos e da OTAN teria sido, essencialmente, a segurança do Ocidente, que se traduziu na retórica da Guerra ao 
Terror. Desestruturar a Al Qaeda e o Talibã eram, em última instância, para o bem dos Estados Unidos, e não para o bem da população afegã.

Rubin (2007, p. 67) relata as lacunas deixadas pela missão da OTAN ao decorrer dos anos de ocupação.

High unemployment is fueling conflict. As a fruit trader in Kandahar put it to me, "Those Afghans who are fighting, it is all because of unemployment". This will only get worse now that the postwar economic bubble has been punctured. Real estate prices and rents are dropping in Kabul, and occupancy rates are down. Fruit and vegetable sellers report a decline in demand of about 20 percent, and construction companies in Kabul report significant falls in employment and wages. A drought in some parts of the country has also led to displacement and a decline in agricultural employment, for which the record opium poppy crop has only partially compensated.

O autor acrescenta que várias partes do país ainda sofrem com falta de energia recorrente, mesmo em Cabul - e não se vê perspectivas de projetos preocupados em desenvolver o setor energético (Rubin, 2007). A falta de prover desenvolvimento de fato se cristaliza no aumento da produção de ópio no Afeganistão. Rubin (2007, p. 69) afirma que "The massive illicit economy, which constitutes the tax base for insecurity, is booming, while the licit economy slows."

Dado que estima-se que a produção dos narcóticos corresponda algo entre 30 e 50\% do PIB total da economia afegã, entende-se que não é apenas com a força da lei que se derruba uma indústria dessa dimensão (Rubin, 2007, p. 77).

Podemos articular o que já foi discutido sobre shadow economies tanto para Pugh (2009) e Duffield (2001; 2007), considerando a economia do ópio como uma representante dessas economias. O crescimento considerável que ocorreu durante os anos de ocupação demonstram que a paz liberal não permitiu com que o bem-estar e o desenvolvimento fossem atingidos com plenitude, embora fosse isso o que a missão prometesse. Inclusive se o desenvolvimento fosse voltado a segurança ocidental. As economias informais florescem na medida em que a política liberal acaba por subjugar, excluir, e ressaltar os problemas socioeconômicos da região, e reforçam as diferenças, muitas vezes, criam novas elites, no local em que está sendo feita a intervenção (Pugh, 2009) - exatamente como ocorreu no caso do Afeganistão. Não é coincidência que a produção da droga tenha se consolidado e consagrado o Afeganistão como maior produtor do mundo nesse mesmo período. Pois, por trás da paz liberal, permanece a crença de que "economic systems and economic behaviour can be changed by external 
agency to achieve a particular developmental model, encompassing social policy, and that interventions can be nuanced to achieve this (Pugh, 2009, p. 79)." Ora, conforme foi amplamente discutido no presente capítulo, a estrutura da sociedade afegã é tribal e étnica. Inúmeras tentativas de inclui-lo no sistema capitalista fracassaram, desde o neocolonialismo.

Pugh (2009) entende que o bem-estar que a paz liberal acaba promovendo, na prática, se baseia em aumentar o consumo: na monetização da vida, na ideia de que a vida melhora quando se adquire algo, ou quando há aumento do poder aquisitivo. Assim, marginalizam-se as reais concepções de bem-estar para determinado país que sofre intervenção. Será que uma necessidade tribal necessita aumento de poder aquisitivo? A paz liberal, então, não reconhece nem legitima as transformações que as economias de sombra, ou ilícitas, estão, na verdade, promovendo (Duffield, 2001; Pugh, 2009). No que se refere as drogas, é emblemático o regime de proibição global, que faz parte de um amplo sistema de governança global liberal. O que aconteceu no Afeganistão não foi novidade. Com a democratização, como parte do projeto da paz liberal, houve a proibição da produção da droga, que antes, era permitida pelo Talibã.

Assim, não apenas a produção da droga se tornou mais lucrativa pelo fato de ter sido proibida, quanto também se tornou a melhor alternativa para subsistência de boa parcela da sociedade - que se traduz, também, na busca pelo bem-estar que a paz liberal não proporcionou. Essa parcela da sociedade não se limita somente a fazendeiros, por exemplo. Como qualquer outra shadow economy, ela penetra diversos âmbitos, tanto sociais quanto políticos. Envolve membros do governo, esquemas de corrupção, e alguns autores apontam até mesmo para o envolvimento de soldados americanos e aliados. Mais do que isso, continuou sendo base de recursos do Talibã. De fato, as drogas como shadow economy no Afeganistão funcionam através de uma rede muito complexa.

Mas, conforme será futuramente analisado, discursivamente, ficava evidente a dualidade de objetos de referência da paz liberal sob o contexto de Estados Unidos em guerra ao terror. Em meio a tal ambiguidade, se a preocupação dos Estados Unidos é, de fato, a sua própria segurança, e, por consequência, a estabilização do Afeganistão, ainda assim, deveria ter focado suas atenções na questão do ópio. 
Any long-term plan for stability must address the poppy problem in a meaningful and effective way, or prospects for peace will be dim. The bulk of opium is produced in the Pushtun areas, increasing both the rish of instability and the likelihood that antipoppy campaigns will be seen as a further attack on Pushtun interests (Their, 2006, p. 490).

Porém, o discurso também se relaciona diretamente com as discussões anteriores de Neocleous, Duffield, Foucault e Jabri do capítulo anterior, como Rubin (2006, p. 177) demonstra:

The US's pursuit of security from both terrorism and challenges to its strategic dominance has different implications from the pursuit of human security through processes of global governance; the two converge to some extent over the intervention in Afghanistan and diverge over the invasion of Iraq. These doctrines, however, constitute different responses to a common problem: maintaining order and security, however and for whomever defined, in an increasingly integrated global system juridically and politically organised around universal state sovereignty. $9 / 11$ teria sido uma tentativa de transformer os estados da periferia.

O escopo da missão incluía ordem e segurança, sob a égide de um estado soberano. Mais do que isso, em diversas ocasiões os Estados Unidos deixaram claro como um dos grandes objetivos era o de se instaurar a democracia no Afeganistão, além de aderência aos direitos humanos (Rubin, 2006). De fato, os dois objetos de referência estão presentes no discurso da presença dos EUA e da OTAN no Afeganistão. Mas o que se observa é que, no campo, conforme o ópio comprovou, a balança pendeu apenas para o lado dos Estados Unidos e de seus aliados - o que também fica claro no discurso britânico, que será analisado nas próximas sessões.

Portanto, essa construção do objeto referente que priorizou os Estados Unidos e seus aliados, produziu exclusões e marginalizações, sobretudo dos indivíduos afegãos. Enquanto os objetos poderiam ter sido os dois, e poderiam ter tomado ações práticas para as duas finalidades, a estratégia excluiu o fato de que havia uma economia do ópio que, crescente, poderia vir a gerar problemas no futuro, e só ações militares não salvariam os Estados Unidos de novos ataques terroristas.

O estado afegão já marginalizava sua população de longa data, como pudemos observar ao longo do panorama histórico fornecido no capítulo anterior. Nem quando havia certo período de estabilidade. Assim, embora, como veremos, Bush tivesse reconhecido que a população afegã passasse por dificuldades e 
graves problemas humanitários, todos eles foram subordinados a operações militares.

Pois talvez fosse mais prático distinguir quem era terrorista e que seria foco de ataques, e exclui-los, do que de fato entender sobre o que estaria fundado todo o sistema insurgente, no caso, do Talibã. A estratégia atingiu apenas a ponta final de toda a estrutura. Mas todos esses atos se justificaram com base no terrorismo, que permitiria o uso da violência e do controle, através da governamentalidade (Jabri, 2006; Duffield, 2001; 2007).

As medidas, em última instância, são tomadas em nome da segurança, que se sobrepõe a qualquer outro valor, conforme revela Jabri (2006). E, conforme discutimos em outro capítulo, entendendo isso como parte da ideologia liberal, enxergamos o que está por trás da paz liberal de fato, ou seja, quais as suas reais motivações.

Ou seja, já no discurso da guerra ao terror, foram criadas exclusões, sobretudo no que se refere aos aspectos humanitários do conflito. No terceiro capítulo, foi feita uma análise a respeito das missões de estabilização, que é o caso da operação da OTAN no Afeganistão. Concluímos que o componente humanitário, ou, no caso, o indivíduo como objeto referente, era secundário em face dos Estados Unidos e dos aliados da OTAN como objetos referentes de fato. Um dos principais indicadores dessa afirmação seria que uma das grandes mudanças em relação a essas operações, é que a assistência humanitária teria sido militarizada. Ou seja, as tropas teriam adquirido tais funções, além de suas convencionais. O que concluímos a partir disso é que já o nome 'estabilização' implica que o objeto referente é o mandante da missão. Estabilizar é para evitar novas ameaças e novos ataques terroristas - mas nos Estados Unidos e nos países aliados.

Em pesquisa promovida para avaliar os efeitos e resultados dos projetos de reconstrução no Afeganistão, sob o contexto da operação de estabilização, conduzido pela Universidade de Tufts (Fishstein \& Wilder, 2011), o resultado foi que a população afegã não se sentiu beneficiada de maneira alguma. Baseado na noção de "winning hearts and minds", ou seja, de que as operações devem conquistar corações e mentes dos afegãos, a pesquisa objetivou justamente analisar se obtiveram sucesso nesse quesito. Assim, o estudo foi feito com base na noção que deriva do nexo entre segurança e desenvolvimento, partindo da ideia de 
que projetos de ajuda humanitária - ainda que, de certa maneira, subordinados melhoram a segurança, e qual a percepção dos afegãos em relação ao que foi empreendido. O estudo revelou que há poucos (praticamente insuficientes) dados empíricos que comprovam tal eficácia. Foram feitas entrevistas e grupos focais em diversas comunidades no Afeganistão, bem como no chifre africano, para fins comparativos.

The chief complaints were that projects were insuficiente both in terms of quantity and of quality; unevenly distributed geographically, politically, and socially; and above all, associated with extensive corruption, especially those that involved multiple levels of subcontracting (Fishstein \& Wilder, 2011, p. 3).

Outra grande descoberta foi que não obtiveram sucesso ao tentar resolver as questões que de fato eram responsáveis por gerar insegurança. Os autores desse estudo, Fishstein e Wilder (2011) relataram que os projetos causaram ainda mais desestabilização devido à corrupção conforme transcrita no texto acima. Para além disso, enquanto havia a crença de que questões de segurança advinham de fatores sócio-econômicos, os autores (Fishstein \& Wilder, 2011), atestam que as causas da insegurança se devem, em sua maior parte, a questões políticas. Assim, os projetos dificilmente se voltavam as devidas causas, o que implicava em gerar ainda mais instabilidade.

Embora a presente pesquisa se utilize em larga escala da questão das drogas como um fator sócio-econômico, não há como ignorar a faceta política dessa questão, sobretudo porque ela move uma grande rede de atores principalmente políticos, bem como uma rede de corrupção bastante extensa para que o tráfico e produção possam acontecer de maneira fluida. Dessa maneira, a contribuição desse estudo para a dissertação se dá na medida em que joga luz sobre a importância dos aspectos políticos locais como componente a ser inserido em um projeto de reconstrução que tenha sucesso e que se atente para o indivíduo local - ou seja, uma reconstrução cujo objeto referente seria a população receptora. Pois, em última instância, o que essa pesquisa que descrevemos demonstrou, os próprios afegãos continuam sofrendo com duras questões relacionadas à segurança. Ora, se a instabilidade no país receptor permanece, questiona-se de que modo isso levaria a crer que o estado mandante também teria garantido a sua própria segurança. 
Mais do que isso, essa pesquisa também enfatiza como o projeto de reconstrução também falhou quanto ao desenvolvimento econômico, principalmente se entendido sob a lente da produção do ópio e seu crescimento vertiginoso.

A pouca atenção que foi dada as drogas, que foram feitas como combate, eram sob o guarda-chuva da campanha de contra-insurgência, portanto, os recursos utilizados foram interdições e erradicações, que, historicamente, são insuficientes. Os resultados são sempre contrários: a produção aumenta, bem como número de viciados. A população de beneficiou tanto de tal cultivo que se rebelou em diversas ocasiões contra esse tipo de combate. Além disso,

A partir de uma seleção de discursos, na próxima sessão, buscaremos comprovar de modo empírico os objetos referentes presentes nos documentos mais relevantes para o conflito em questão.

\section{1 \\ O Acordo de Bonn}

A análise do acordo de Bonn, base dos mandatos das missões no Afeganistão, nos permitirá entender: Quem são os atores securitizadores, que definem os objetos de referência? Quais os objetos de referência? Quais outras implicações, adjetivos, pressupostos, predicativos envolvidos nesses discursos?

O Acordo de Bonn será o primeiro documento a ser analisado pois é ele quem estabelece as bases para as futuras resoluções do Conselho de Segurança sobre o Afeganistão. É nele também que é definido o mandato da ISAF, que, em agosto de 2003 passará a ser coordenada pela OTAN.

A primeira determinação do acordo versa sobre encerrar o conflito no Afeganistão e promover paz, reconciliação nacional, estabilidade e respeito aos direitos humanos. Assim, em primeiro lugar, o que importa nesse parágrafo é que o Afeganistão e seus indivíduos estão colocados como objetos de referência. Em segundo lugar, é preciso entender os pressupostos. Entende-se que o Afeganistão, sob o poder do Talibã, é instável e não respeita os direitos humanos. Além disso, pressupõe-se também que o país encontra-se sob um conflito, que é associado ao adjetivo "trágico". Aqui notamos a subordinação do sul, subdesenvolvido, 
violento e instável, presente na caracterização discursiva construída sobre o Afeganistão.

Determined to end the tragic conflict in Afghanistan and promote national reconciliation, lasting peace, stability and respect for human rights in the country,

Reaffirming the independence, national sovereignty and territorial integrity of Afghanistan,

Acknowledging the right of the people of Afghanistan to freely determine their own political future in accordance with the principles of Islam, democracy, pluralism and social justice (ONU, 2001),

Os dois parágrafos seguintes reafirmam a centralidade do Afeganistão para o acordo. Há, inclusive, menção ao indivíduo afegão, e notadamente a preocupação com sua liberdade, de maneira democrática, pluralística, mas que esteja de acordo com os princípios islâmicos.

Afeganistão é repetida diversas vezes ao decorrer do documento. O próximo parágrafo transcrito já chama atenção ao caráter urgente da situação, e, em seguida, outro explicita como a preocupação é eminentemente construir segurança.

Aware that the unstable situation in Afghanistan requires the implementation of emergency interim arrangements and expressing their deep appreciation to His Excellency Professor Burhanuddin Rabbani for his readiness to transfer power to an interim authority which is to be established pursuant to this agreement,

( ...)

Recognizing that some time may be required for a new Afghan security force to be fully constituted and functional and that therefore other security provisions detailed in Annex I to this agreement must meanwhile be put in place (ONU, 2001),

Até então, Afeganistão é entendido como objeto de referência do acordo firmado. A caracterização do Afeganistão se utiliza de adjetivos tais como instável, acompanhados de terrorismo, opressão. Em especial a palavra "instabilidade" como característica é repetida diversas vezes ao decorrer do documento.

Os anexos do documento são responsáveis por estabelecer as bases das missões a serem enviadas. No que tange ao mandato da ISAF, existe 
reconhecimento inicial no texto de que caberia aos afegãos a manutenção da própria segurança. No entanto, acrescentam que para atingir tal capacidade com plenitude, precisam de assistência da comunidade internacional. Assim, o acordo pede ao Conselho de Segurança das Nações Unidas que autorizem o envio de tropas.

Porém, foi determinado a princípio que as forças seriam enviadas apenas para Kabul, mas aberto a possibilidade de que poderia haver expansão para outras áreas.

1. The participants in the UN Talks on Afghanistan recognize that the responsibility for providing security and law and order throughout the country resides with the Afghans themselves. To this end, they pledge their commitment to do all within their means and influence to ensure such security, including for all United Nations and other personnel of international governmental and nongovernmental organizations deployed in Afghanistan.

2. With this objective in mind, the participants request the assistance of the international community in helping the new Afghan authorities in the establishment and training of new Afghan security and armed forces (ONU, 2001).

Já o website da OTAN, na página que diz respeito a $\operatorname{ISAF}^{11}$, lista de maneira objetiva qual a missão e objetivos das tropas. Além de ajudar (os termos, com ficará ainda mais evidente, variam entre prestar assistência ou ajudar - clara relação de hierarquização colocando o Afeganistão como incapaz de erguer suas próprias forças) o governo afegão a estender sua autoridade e tornar o ambiente mais seguro, acima de tudo. É uma missão para estabilizar, para levar segurança ao Afeganistão, e ela ocorre em conjunto com o exército nacional afegão. Ela também cumpriria a função de treinar esse exército e desenvolvê-lo para que possa atender a realidade do conflito (OTAN, s.d.).

Porém, no que tange a reconstrução, embora salientem que tenham papel importante no sentido de identificar necessidades, a ISAF se diz como apoio. E para o que nos vale, dizem também prover apoio as ações de combate as drogas, embora não possam se envolver diretamente nos processos. Isso é clara referência a relutância por parte dos Estados Unidos em tomar parte desse elemento do conflito. O último elemento, ou seja, a última prioridade da lista, é dar suporte a

${ }^{11}$ OTAN, s.d. Disponível em: <http://www.nato.int/cps/en/natohq/topics_69366.htm> 
assistência humanitária. O que tal lista nos faz notar, portanto, é que tanto a questão do ópio quanto humanitárias são praticamente marginalizadas no escopo da missão.

Em outro anexo, é feita menção a importância aos princípios de integridade territorial e não-intervenção na política interna, e que devem ser levados em conta durante as operações a serem enviadas ao Afeganistão. Ao mesmo tempo, pedem ajuda a comunidade internacional para reconstruir o país, reabilitá-lo e recuperá-lo. É estabelecido também que uma assembleia constituinte será realizada para desenvolver a nova constituição do Afeganistão.

1. Request that the United Nations and the international community take the necessary measures to guarantee the national sovereignty, territorial integrity and unity of Afghanistan as well as the non-interference by foreign countries in Afghanistan's internal affairs;

2. Urge the United Nations, the international community, particularly donor countries and multilateral institutions, to reaffirm, strengthen and implement their commitment to assist with the rehabilitation, recovery and reconstruction of Afghanistan, in coordination with the Interim Authority;

Por fim, há um último parágrafo que faz menção a questão das drogas no Afeganistão.

6. Strongly urge that the United Nations, the international community and regional organizations cooperate with the Interim Authority to combat international terrorism, cultivation and trafficking of illicit drugs and provide Afghan farmers with financial, material and technical resources for alternative crop production.

Há um pedido para que haja cooperação para combater a produção e tráfico do ópio, mas é colocada depois do combate ao terrorismo. Sugerem o fornecimento de materiais e técnicas para cultivos alternativos. Ou seja, é o terrorismo quem é securitizado de fato no conflito, e as drogas ficam como elemento secundário, que recebe poucos recursos ou atenção.

Observamos que o objeto de referência da OTAN não é monolítico, e é possível identificar mais de um ao decorrer dos documentos e discursos. No entanto, alguns são colocados como prioridades em face de outros, e isso também ficará evidente nos discursos dos presidentes americanos - enquanto os britânicos são mais explícitos quanto à suas preferências e motivações. Isso refletiu na condução de suas políticas quanto ao combate a produção de ópio no Afeganistão, 
em que, muito embora os britânicos tenham ficado responsáveis pelas áreas mais críticas nessa questão, não a trataram como prioridade e o aumento da produção foi evidente ao longo dos anos.

\section{2}

\section{A Participação do Reino Unido no Conflito}

A despeito da participação do Reino Unido tanto na Operation Enduring Freedom quanto na ISAF, o que já foi levantado tanto no terceiro capítulo quanto retomado aqui é que os britânicos entraram no Afeganistão com a clara missão de estabilização, e com os próprios britânicos como objetos referentes. Assim, o que entendemos é que o objeto de referência da OTAN em geral não é monolítico, e observamos que varia de aliado e suas respectivas PRTs.

No caso específico britânico, veiculam em seus próprios websites os seguintes discursos, organizados nas páginas sob "Policy":

We are in Afghanistan for one overriding reason - to protect our national security by helping the Afghans take control of their own.

We are helping the Afghan government to develop its ability to maintain security, so that it can prevent the return of international terrorists, such as Al-Qaeda, to Afghanistan.

Preventing the return of international terrorists has been the most important part of our work in Afghanistan and the terrorist threat to the UK from this region has been substantially reduced. The UK has played an important role in developing and training Afghan security forces. UK support has also helped Afghanistan to become a more viable state; one that can provide basic services, improve the lives of its ordinary citizens and reduce instability ${ }^{12}$.

Explicitam que, em primeiro lugar, o único motivo pelo qual estão no Afeganistão é pela proteção de sua própria segurança nacional. E a maneira pelo qual fazem isso é ajudando os próprios afegãos a controlar a própria segurança deles. Assim, o que podemos depreender desse texto é que, em primeiro lugar, de fato o objeto referente é a segurança nacional britânica. Em segundo lugar, colocam os afegãos como pessoas que precisam de ajuda, e que apenas com a ajuda britânica poderão se organizar e possibilitar com que haja segurança para todos. Há, portanto, uma relação claramente hierárquica de que é preciso com que se leve ajuda para que o governo afegão possa desenvolver suas próprias

12 GOVERNO do Reino Unido, s.d. Disponível em: <https://www.gov.uk/government/policies/establishing$\underline{\text { stability-in-afghanistan> }}$ 
habilidades. Porém, não para o bem do próprio povo, mas sim, pelo bem da segurança nacional britânica. A palavra "ajuda" (help) é recorrente ao longo do texto.

A range of international partners are also working in Afghanistan to develop security, governance, infrastructure, economy and the Afghan government's ability to provide essential services.

A reconstrução do Afeganistão - mas para o bem-estar do próprio Afeganistão - é explicitamente colocada como algo secundário. A relação é de fato hierarquizada entre o Reino Unido, altamente capacitado para levar, como eles próprios dizem, ajuda, aos afegãos, instáveis e sem recursos.

Outro documento, emitido pelo Ministério da Defesa Britânico, reitera a única motivação por trás da presença britânica no Afeganistão. Mas acrescenta que não há uma busca por um Afeganistão perfeito, colocado nesses mesmos termos, mas a preocupação é exclusivamente é a estabilidade, e, consequentemente, segurança. O Afeganistão, tal como representado no texto, é um "safe-haven" para terroristas, e não um local estável.

British forces are in Afghanistan for one overriding reason: to protect our national security by helping the Afghans take control of theirs. This means building up the capability of the Afghan National Security Forces (ANSF) so that they can prevent Afghanistan from ever again becoming a safe-haven for international terrorists. The UK Government does not seek a perfect Afghanistan, but rather a stable Afghanistan that is able to manage its own security effectively ${ }^{13}$.

A despeito do combate ao ópio, de modo como liderado pelo Reino Unido, há reconhecimento quanto a dificuldade e quanto ao fracasso das tentativas de erradicação e interdição.

No site do exército britânico, na página relativa ao PRT em Helmand ${ }^{14}$, a zona de maior produção de ópio, descrevem como a produção ainda é um dos maiores desafios, sobretudo porque ali é a área de maior índice de produção da droga no Afeganistão.

Opium production still remains a very serious problem in the region. The UK has played a role in trying to tackle the drugs trade, including helping Afghan authorities to eradicate poppy fields. We have also helped farmers to grow

13 GOVERNO do Reino Unido, 2014.Disponível em: <https://www.gov.uk/government/uploads/system/uploads/attachment data/file/363081/tlm October2014 pdf>

14 EXÉRCITO do Reino Unido, s.d. Disponível em: <http://www.army.mod.uk/operationsdeployments/22802.aspx> 
alternative legal crops. But results have been varied, with the worst results to date reported in 2013 (United Nations Office on Drugs and Crime report, 2013). Tackling the narcotics trade will be a long, uphill battle.

After 2014 we will continue to help the Afghan government develop its law enforcement capabilities. Afghan counter narcotics police have already tripled their drugs seizures in recent years. We will also work with partners to disrupt supply networks. Wider efforts to support the Afghan government build its security, economic development and good governance will also, in the longerterm, promote better conditions for tackling the drugs trade.

Declaram que tentaram erradicar os campos de plantio da papoula, e que ajudaram fazendeiros a desenvolver cultivos alternativos, mas reconhecem que não obtiveram sucesso, sobretudo porque em 2013, segundo o UNODC (2013), o Afeganistão teve produção recorde. Portanto, reiteram que é um desafio e uma longa batalha para as tropas britânicas que estavam instaladas na província. As atividades da PRT britânica se encerraram em março de 2014.

\section{3 Os Estados Unidos sob Mandato de George W. Bush}

O primeiro discurso de George W. Bush a ser analisado muito provavelmente é um dos mais emblemáticos, na medida em que define qual o objeto de referência de fato da operação que ainda estava a ser enviada. Discutimos até então que o objeto não é monolítico, como veremos em outros discursos, no entanto, dado que a missão não cumpriu seus objetivos e marginalizou o indivíduo afegão, vemos que houve priorização de um objeto em detrimento dos outros.

Assim, o discurso de Bush deixa evidente como o objetivo final é a guerra ao terror, e a guerra ao ópio é relegada e não chega a ser securitizada. O conflito ocorreria para evitar que novos ataques terroristas ameaçassem os Estados Unidos internamente, de modo que foi criado até mesmo um novo departamento dentro do governo americano que se responsabilizaria exclusivamente pela segurança nacional, do território americano. O departamento ficaria responsável, inclusive, pela administração de entradas e saídas dentro do território americano.

O primeiro trecho se refere ao Afeganistão e suas relações com a Al Qaeda e o Talibã. É e primeira oportunidade do presidente, em face dos atentados, de construir a situação como uma verdadeira ameaça contra a integridade da nação 
americana. É a chance de construir o inimigo, envolto sob a denominação de terrorista, no caso, a Al Qaeda, que atua em conjunto com o Talibã, que será caracterizado como um regime brutal.

The leadership of Al Qaida has great influence in Afghanistan and supports the Taliban regime in controlling most of that country. In Afghanistan, we see $\mathrm{Al}$ Qaida's vision for the world. Afghanistan's people have been brutalized. Many are starving, and many have fled. Women are not allowed to attend school. You can be jailed for owning a television. Religion can be practiced only as their leaders dictate. A man can be jailed in Afghanistan if his beard is not long enough (Bush, 2001).

Assim, Bush constrói a imagem que ele quer que seu público tenha tanto do Afeganistão, quanto da Al Qaeda e do Talibã; o país vem acompanhado de predicativos tais como fome, direitos desiguais, religião fundamentalista, leis rígidas. Isso servirá para compor a ideia de que o Afeganistão precisa de ajuda, e apenas os Estados Unidos (e seus aliados) seriam capazes de ajudar.

O próximo parágrafo destaca o povo afegão; e como os Estados Unidos são a maior fonte de assistência humanitária. O respeito, assim, advém do fato de que podem ajudar esse povo - e salvá-los do Talibã, que fornece segurança e alojamento a Al Qaeda.

The United States respects the people of Afghanistan - after all, we are currently its largest source of humanitarian aid - but we condemn the Taliban regime. It is not only repressing its own people; it is threatening people everywhere by sponsoring and sheltering and supplying terrorists. By aiding and abetting murder, the Taliban regime is committing murder (Bush, 2001).

A despeito da retaliação, Bush descreve que ela não se limitará a ações $a d$ hoc e algumas poucas batalhas, mas que os americanos devem esperar por um longo conflito. O conflito poderá envolver, segundo os próprios adjetivos usados, batalhas e ataques dramáticos, que poderão ser vistos na TV. Por fim, ele declara a guerra ao terrorismo, e pede aos outros estados que ou se aliem aos Estados Unidos ou aos terroristas, em uma guerra que só tem dois lados. E qualquer um que optar por se juntar aos terroristas, também será combatido e visto como hostil, segundo a própria linguagem utilizada por Bush. Assim, a construção do inimigo se vale pelo uso de adjetivos tais como hostil, e regimes que não democráticos ou não condizentes com valores liberais também serão vistos com maus olhares. Por fim, é nesse mesmo discurso em que Bush também anuncia a criação do Office of 
Homeland Security - que é um claro indicador dos americanos como objeto referente de fato.

Bush (2001) discursou também no momento do início dos ataques ao Afeganistão, a princípio aéreos sob a Operation Enduring Freedom. A justificativa da oficialização dos ataques era a de que o Talibã não havia entregue os líderes da Al Qaeda, e que, portanto, pagaria o preço por isso.

O próximo parágrafo é emblemático. Aqui, há destaque novamente para o povo afegão, que é construído como um povo oprimido. Os americanos, por sua vez, são caracterizados pela sua generosidade. Além disso, se colocam como 'amigos' de todos os muçulmanos ao redor do mundo. Ou seja, o discurso de Bush é construído de modo a diferenciar quem é amigo e quem é inimigo.

At the same time the oppressed people of Afghanistan will know the generosity of America and our allies. As we strike military targets we will also drop food, medicine and supplies to the starving and suffering men and women and children of Afghanistan. The United States of America is a friend to the Afghan people. And we are the friends of almost a billion worldwide who practice the Islamic faith (Bush, 2001).

O nome da missão no Afeganistão e sua respectiva explicação simbolizam como a motivação por trás da operação está, na verdade, pautada pela preocupação com a segurança nacional americana.

We did not ask for this mission. But we will fulfill it. The name of today's military operation is Enduring Freedom. We defend not only our precious freedoms but also the freedom of people everywhere to live and raise their children free from fear (Bush, 2001).

Comprovando a argumentação de Neocleous, apresentada anteriormente, liberdade, seria então, a sensação de estar livre de medos, a sensação de segurança, que é o que a operação pretende promover para a população americana - liberalismo e seus valores, no fim, como sendo praticamente exclusivo aos americanos.

\section{4}

\section{O Conflito Durante o Governo Obama}

Durante o governo Obama, embora houvesse a promessa de retirada das tropas, que foi adiada até que, ao final de 2014, foram severamente reduzidas e a ISAF se encerrou, a retórica pouco mudou, com relação ao discurso de Bush. 
Em discurso em 2009 (Obama, 2009), ele reitera que a motivação da presença no Afeganistão se deve a preservação da segurança nacional. O primeiro fator relevante de seu discurso é a importância dada ao aspecto militar, declarando que havia intenção de se manter os Estados Unidos como maior força militar do mundo, tudo em troca da segurança nacional. É em seguida que ele faz menção ao Afeganistão. Ou seja, a ordem dos assuntos é bastante indicativa do quanto é a segurança que importa. Ainda havia a preocupação em se evitar futuros ataques terroristas, e terminar com a Al Qaeda de uma vez por todas.

The President and the Nation's military leadership have put forward a strategy for Afghanistan and Pakistan so that all elements of national power are engaged and integrated in an effort to defeat al Qaeda and prevent attacks on the homeland as well as on U.S. allies and partners. In Iraq, the United States is moving forward with a responsible drawdown of combat forces, having transferred security responsibilities to Iraq's forces. The legislation, as approved by the Committee, provides critical resources to enable this to happen (Obama, 2009a).

Em discurso de junho em 2014 (Obama, 2014), ano que seria anunciado o fim da ISAF, o presidente Obama retoma que a operação no Afeganistão foi, em primeiro lugar, para evitar novos ataques contra os Estados Unidos. A partir do final de 2014, apenas um contingente reduzido seria mantido. Ele discursa sobre sua decisão de realizar a transição, para que as forças do Afeganistão que teriam sido treinadas ao decorrer desses anos, possam administrar a própria segurança. Ressalta, inclusive, qual a missão da ISAF, que é essencialmente para estabilidade e segurança, enquanto as funções humanitárias estão subordinadas:

The mission of ISAF, under North Atlantic Treaty Organization (NATO) command and in partnership with the Government of the Islamic Republic of Afghanistan, is to reduce the capability and will of the insurgency, support the growth in capacity and capability of the Afghanistan National Security Forces (ANSF), and facilitate improvements in governance and socio-economic development in order to provide a secure environment for sustainable stability. Forty-eight nations, including the United States and all 28 NATO members, contribute forces to ISAF. For the last few years, the ISAF campaign has focused on preparing the ANSF for full security transition in 2014 (Obama, 2014a).

Já em discurso em dezembro do mesmo ano (Obama, 2014) agora ele de fato vislumbra um final para a guerra, e relembra os valores do cerne do liberalismo americano: a liberdade, a prosperidade, e explicita, inclusive, a segurança como parte desse conjunto. 
As we go about our days, as we gather with loved ones and friends, it's important to remember: Our way of life-the freedom, prosperity and security that we enjoy as Americans-is not a gift that is simply handed to us. It has to be earned, by every generation. And no one sacrifices more to preserve our blessings than our extraordinary men and women in uniform (Obama, 2014b).

No entanto, a segurança é colocada como algo a ser conquistada, embora faça parte da vida dos americanos. É algo que se deve sacrificar para se poder atingir. Por isso, ele dá destaque ao valor que os soldados que os servem teriam, em face da importância que a segurança tem. Assim, nesse momento, o que podemos interpretar que, novamente, os Estados Unidos são colocados como principal objeto referente. Isso se confirma no parágrafo seguinte, em que Obama retoma os atentados de 2001, utilizando os termos de que a nação teria sido atacada.

That's why, on Monday, I'll be visiting our troops at Joint Base McGuire-DixLakehurst in New Jersey, to salute them for their service and thank them for their sacrifices. Since our nation was attacked on $9 / 11$, these men and women, like so many others in uniform, have met every mission we've asked of them. They deployed to Afghanistan and Iraq. In more than a decade of war, this 9/11 generation has worked with the Afghan people to help them reclaim their communities and prevent terrorist attacks against our own country (Obama, 2014b).

Aqui, o trabalho em conjunto com a população afegã foi para, além de ajuda-los a reconstruir a própria nação, também para prevenir ataques terroristas aos Estados Unidos. Aparece uma clara dualidade de objetos de referência, ainda que permaneça o destaque para os americanos. A ideia que permanece é de que é de que deseja-se sempre para evitar um novo ataque aos Estados Unidos ou aliados da OTAN.

Of course, the end of our combat mission in Afghanistan doesn't mean the end of challenges to our security. We'll continue to work with Afghans to make sure their country is stable and secure and is never again used to launch attacks against America (Obama, 2014b).

Os predicativos associados ao Afeganistão também permanecem sendo: ajuda, estabilidade, segurança, evitar ataques contra a América.

The troops I'll visit on Monday have been part of our mission to degrade and ultimately destroy ISIL in Iraq and Syria. They've been supporting our efforts in West Africa to fight the Ebola epidemic and save lives. Because in time of crisis and challenge, the world turns to America for 
leadership. And when the world calls on America, we call on the brave men and women of our armed forces to do what no one else can (Obama, 2014b).

O final merece atenção especial. Como pressuposto, Obama coloca os americanos e seus soldados como se fossem chamados pelo mundo para resolver qualquer conflito, pois eles seriam os únicos com capacidade para tal. Os adjetivos merecem destaque: "brave", ou seja, corajosos. E o mundo sempre se volta e espera dos americanos a salvação. Muito embora as questões no Afeganistão se encontram muito longe de serem resolvidas, cristalizadas no contínuo aumento da produção dos narcóticos.

Em nenhum momento, desde os discursos de Bush, há menções ao bem estar, enquanto que a noção de desenvolvimento, como parte dessa retórica ligada ao conflito no Afeganistão, está necessariamente ligada ao fato de ele é ajudará a trazer estabilidade e segurança, que, em última instância, ao final da corrente, é para os Estados Unidos.

Quanto ao ópio, em pesquisa feita na database The American Presidency Project, foram poucas as aparições da questão. A pesquisa utilizou como palavras chave "Afghanistan" e "opium" entre os períodos das gestões de George W Bush e Barack Obama, até 2014, entre setembro de 2001 e dezembro de 2014.

Uma rara aparição, porém a com maior destaque, em discurso do dia 22 de janeiro de 2009 (Obama, 2009b):

The American people and the international community must understand that the situation is perilous and progress will take time. Violence is up dramatically in Afghanistan. A deadly insurgency has taken deep root. The opium trade is far and away the largest in the world. The Afghan Government has been unable to deliver basic services. Al Qaida and the Taliban strike from bases embedded in rugged, tribal terrain along the Pakistani border. And while we have yet to see another attack on our soil since 9/11, Al Qaida terrorists remain at large and remain plotting.

Associa-se o ópio a incapacidade administrativa afegã, e os Estados Unidos não assumem a parcela de culpa que detém desse processo alarmante de números crescentes.

O que observamos, de maneira geral, é que muito pouco mudou entre a retórica de Bush e Obama. A presença da ideia de Afeganistão conectada com terrorismo permaneceu, envolto pelas palavras "ameaça", "instabilidade", ou seja, mesmo a caracterização, ou construção da imagem do Afeganistão, permaneceu a mesma. 
Para além de nuances entre as retóricas dos dois presidentes, as análises aqui nos revelam, acima de tudo, como, mesmo nos discursos, a presença da população afegã foi marginalizada. A segurança nacional, seja ela americana, ou britânica, ou a estabilidade do sistema internacional foram colocadas sempre em primeiro lugar, mesmo se houvesse menção aos indivíduos. Dessa forma, o objeto referente da paz liberal depois dos atentados de 11 de setembro de 2001, é, principalmente, a segurança nacional do(s) estado(s) mandante(s) da intervenção seja ela no Afeganistão, ou seja no Iraque. Mesmo que haja presença sutil na retórica do afegão como outro objeto referente, na prática não foi o que ocorreu, conforme a análise com relação a produção do ópio nos comprovou. Assim, a herança do liberalismo como tradição filosófica na paz liberal nesse momento pós 11 de setembro é quase imperceptível. O liberalismo, em sua retórica, propagava um ideal de que o indivíduo era o cerne de seus valores, a quem deveria se garantir direitos, liberdade, participação política e bem-estar, em forma de propriedade privada, economia de mercado e livre-comércio.

Embora as operações de peacebuilding, aqui, no caso, no Afeganistão, promovam algum de tais elementos, tais como economia de mercado, o bem-estar não foi atingido, pois economias paralelas foram buscadas para suprir tal demanda. 


\section{A Paz Liberal como Segurança para o Ocidente e seus Objetos Referentes}

As sessões anteriores se voltaram para fornecer o arcabouço teórico para o desenvolvimento do argumento do presente trabalho. Foi preciso, em primeiro lugar, traçar as origens do liberalismo, o papel do indivíduo, e qual o caminho que foi feito até a origem das operações de peacebuilding. Tais operações carregam em si e procuram transmitir, sobretudo através do discurso, os valores da tradição liberal, que compreendem, entre outros, a importância do indivíduo e de sua liberdade, que desencadeiam em todo um conjunto de ideais e instituições.

O capítulo seguinte, por sua vez, objetivou estabelecer as bases para se poder discutir as operações de peacebuilding no âmbito da segurança. Desse modo, foi necessário discorrer sobre qual o caminho que os estudos de segurança nas Relações Internacionais percorreram, no que consiste a concepção de segurança per se, e quais as ferramentas teóricas que nos possibilitarão entender o que está por trás do projeto da Paz Liberal. Os próximos capítulos se debruçaram nas práticas da paz liberal, em dois períodos: antes e depois dos atentados de 9/11, seguidos de um estudo de caso sobre o Afeganistão, e uma análise de discurso com base em documentos sobre esse conflito específico.

Dessa maneira, o presente capítulo parte das colocações anteriores e da investigação empírica para traçar que concepção de segurança por trás do projeto da paz liberal. Procurar-se-á responder qual o objeto de referência na prática, ou de fato, das operações de peacebuilding, com base na existência da dualidade entre dois possíveis objetos: o estado mandante da missão, ou os indivíduos do local que recebeu a operação. $\mathrm{Ou}$, se são ambos no discurso, qual deles de fato 
será na prática? Quais objetos de referência estão por trás das operações de paz? Outra questão que emerge se relaciona com os atentados terroristas do dia 11 de setembro de 2001. De que modo podemos entender que houve uma mudança no objeto de referência da agenda política após esse evento? E no que isso implica? Que tipo de concepção de segurança podemos determinar por trás do projeto?

Para poder responder tais perguntas, retomaremos pontos importantes construídos ao longo do trabalho para apresentar o argumento e as descobertas de maneira consistente.

Nos focaremos em responder as questões relacionadas ao objeto de estudo: a paz liberal. O estudo de caso no Afeganistão foi utilizado como instrumento para comprovar empiricamente a argumentação proposta. Examinaremos quais as lacunas existentes entre o discurso e a prática, e quais as implicações e marginalizações decorrentes dessa distância. Partiremos de conceitos e suas aplicações para analisar as duas instâncias e suas consequências.

\section{1}

\section{As Lacunas entre Retórica e Prática}

Uma das principais descobertas da pesquisa foi a constatação de que há uma significante lacuna entre a retórica e a prática em respeito a paz liberal. Já foi apresentado, principalmente através de Duffield (2001; 2007), que um dos principais focos da governança global é o de se impor o projeto da paz liberal nos países do sul global, subdesenvolvidos, que apresentam ameaças, de modo que tal projeto visa, em última instância, estabilidade, consequentemente, a segurança. A paz liberal implementaria instituições, economias de mercado, democracia e resolução de conflitos para que se cessassem e não houvesse recorrência

Porém, o projeto provocou reações e consequências bastante diferentes do que foi exposto através da retórica e na agenda política. Tschirgi (2003), por exemplo, diz que uma das principais questões que emergiu devido a paz liberal e o nexo entre segurança e desenvolvimento foi que houve se aumentou a lacuna existente entre os interesses políticos e de segurança de governos (do norte) em face das necessidades dos países do Sul. 
Chandler (2007), por sua vez, enxerga essa agenda já como subordinadora dos interesses do Sul, e que a intenção de se reduzir pobreza e criar estabilidade infere um desejo de se conter que a instabilidade de tais regiões se dissipe, o que subentende-se que há uma securitização da agenda de desenvolvimento, com o que Duffield (2001), concorda.

Chandler (2007) joga luz sobre o fato de que há uma extensa lacuna entre a retórica política pautada pela paz liberal e a implementação delas de fato, no campo, na prática. Estão desconectados em diversos âmbitos: "Rather than clarity, the security-development nexus sets up a framework where any external regulatory or interventionist initiative can be talked up by the proposing government or institution as being of vital importance (Chandler, 2007, p. 363)".

Há um desejo de se priorizar a retórica frente a responsabilidade política; também espera-se que as ONGs ajam mais - ou seja, empurram as responsabilidades para as ONGs. E quase não há ligação entre a retórica e as políticas, de modo que o mundo não ocidental é entendido de forma simbólica (Chandler, 2007). Essa argumentação também aponta para o fato de que o indivíduo não é central, logo, não é objeto de referência prioritário aqui. Mais do que isso,

The redefinition of both development and security in terms of outcomes on the most marginal sectors of society reflects the reduced aims of international policymaking, reducing foreign policy to the level of policy rhetoric rather than practical consequences. It is therefore unsurprising that commentators often highlight the "stark asymmetry between the resources that are assigned to sectoral programming and the expectations that accompany it', with the agencies involved lacking both resources and capacity, and therefore 'can barely make an identifiable dent in the problem with which one is grappling' (IPA 2004a: 9). The merging and redefinition of the ambitious aims of development and security programmes down to a narrow focus on the governance and administration of the non-Western state and to the immediate conditions of marginalized groups has meant that larger questions of economic and social transformation have been removed from the agenda (Chandler, 2007, p. 377).

Salientamos, portanto, a existência de uma grande lacuna entre retórica e prática, em que a política é desenvolvida de maneira isolada e reticente quanto as reais necessidades do que ocorre no campo. No discurso, o objeto de referência é o indivíduo, como o projeto da paz liberal age sob influência da segurança humana, realiza suas operações com foco no bem-estar, na segurança multifacetada, e na liberdade dessas populações. Além disso, há, por trás da ideia de segurança humana, tal como promovida pelo peacebuilding, uma noção de 
emancipação, que só seria possível através da intervenção. Ou seja, uma relação paradoxal em que para se atingir a liberdade e a segurança, é necessário adotar um modelo ocidental, que, conforme já foi discutido, não é baseado em tradições da sociedade local. O indivíduo, na medida em que não é priorizado como objeto referente, deixa instantaneamente de ter a chance de se emancipar. Nesse sentido, conforme colocado por Krause e Williams (1997) o próprio estado, sob os moldes ocidentais, imposto sobre tais indivíduos, se torna uma ameaça à emancipação dessa população. Isso se relaciona intimamente com a discussão proposta por Neocleous (2008) e a concepção de estado que deriva do liberalismo tradicional: troca-se a liberdade pela provisão da segurança, por meio do contrato social.

Assim, a paz liberal agindo, sob a força discursiva da segurança humana poderia indicar que é pautada por uma concepção aprofundada de segurança, porque não implicaria em ações apenas voltadas à segurança nacional. Porém, o que uma análise mais profunda do liberalismo e seus reflexos no nexo entre segurança e desenvolvimento, além de observar os próprios textos da ONU Agenda Pela Paz - o que verificamos é que, no fundo, o estado nunca foi deixado de lado como objeto referente. Ele ainda é tido, pela própria organização, como o ente soberano, como o ator principal. E, tal como o liberalismo prega, o estado é responsável por prover segurança aos indivíduos, e apenas dessa maneira, poderá ter acesso a sua liberdade. Ou seja, existe a todo momento, uma concorrência entre os objetos. Os atentados do dia 9/11 provocaram uma mudança na inclinação, ou tendência, de um objeto em face do outro.

\section{2}

\section{O Impacto dos Atentados de 11/9 no Objeto Referente da Paz Liberal}

Um dos principais elementos que foi verificado ao longo dessa pesquisa é que houve uma mudança, tanto retórica quanto prática, em operações de peacebuilding após os atentados do dia 11/9. Tal mudança, inclusive, fez com que o peacebuilding, enquanto representação última da paz liberal e sua operacionalização, atravessasse mudanças e que se distanciasse de determinados valores tidos como centrais ao liberalismo, (se não, o principal): o indivíduo, sua liberdade e bem-estar. Em detrimento de uma preocupação com a segurança dos 
estados mandantes, o indivíduo para o qual a paz liberal seria levada, foi relegado as margens. Ou seja, em outros termos, houve priorização de um objeto referente - no caso, os estados mandantes - em face de outros. Enquanto outros elementos, como economia de mercado, livre comércio, participação política através da representação democrática e instituições continuam a ser implementadas, o indivíduo, e, principalmente, seu bem-estar e liberdade fossem os motivos por detrás dos outros valores, mais concretos, não foi levado em questão. O liberalismo, sobretudo o tradicional, propõe que economia de mercado e livre comércio, por exemplo, sejam estimulados em prol do bem-estar que todos os indivíduos teriam, pois todos sairiam ganhando e poderiam consumir livremente.

A análise de discurso deixou evidente o quanto isso ficou explícito em discursos de governantes: presidentes americanos e órgãos do governo britânico foram claros quanto as suas respectivas seguranças nacionais como objetos referentes.

A despeito, portanto, da concepção de segurança por trás dessa mudança na paz liberal, ela remeteria à uma noção tradicional, que, conforme foi apresentado, a preocupação de fato reside na estabilidade do sistema de estados, ou seja, do sistema internacional, no qual os únicos atores políticos são os estados soberanos.

Consequentemente, isso provocou em um processo de securitização do sul, em face do norte, a saber, dos estados que compõem o norte global, que creem que os estados do sul, em desenvolvimento, são ameaças potenciais à estabilidade e a segurança internacional.

A Paz Liberal, conforme definida pelos seus principais críticos, representa um projeto hegemônico e ideológico cujas tradições remontam ao conjunto de ideias que compõem o liberalismo somado à herança kantiana de A Paz Perpétua (Richmond, 2005). O cerne de tal tradição se pautaria pela valorização do indivíduo e de sua racionalidade (Doyle, 2012). É, portanto, uma ética que sugere privilégio aos indivíduos (Richmond, 2011).

Uma outra descoberta da pesquisa, portanto, seria de que a paz liberal estaria focada em prover segurança ao norte. Em outras palavras, na concorrência entre objetos referentes, prevalece, nesse caso, o ocidente. Embora a ética liberal sugira o privilégio total aos seus indivíduos, um modelo é imposto a determinados 
indivíduos, mas de modo que os últimos são subordinados e marginalizados pois representam uma ameaça. Um modelo que trará progresso, desenvolvimento e segurança se sobrepõe as necessidades e valorização do indivíduo local. Mas se houvesse aderência a ética liberal de fato, não seria ao indivíduo local também que deveria ser garantido o bem-estar e liberdades através de todos os aparatos institucionais levados pela paz liberal?

Goodhand e Sedra (2013) atentam para o caráter de antídoto ao conflito interno presente no peacebuilding. Tanto os referidos autores quanto Duffield (2001) ressaltam como é uma estratégia transformativa. O modo de vida do indivíduo receptor deve ser inteiramente modificado e readequado aos moldes liberais. Sobretudo para que seja possível o uso de tecnologias de controle e de segurança para conter qualquer possível recorrência de conflito que ameace o norte e sua estabilidade. Assim, essa agenda se operacionaliza tanto através da implementação de tais tecnologias quanto através de todas as reformas ditas liberais que são propostas pela governança global. Além do conjunto de valores presentes na retórica - bem-estar e liberdade do indivíduo, democracia, economia de mercado, e instituições, o peacebuilding também emprega mudanças estruturais quanto a constituição local, conduzem reformas em diversos setores governamentais (sobretudo segurança), promovem desenvolvimento rural e outras reformas econômicas para que haja adequação para inserção em uma economia de mercado. Ou seja, é uma transformação completa nas bases estruturais de um governo, que ocorre de maneira radical e imposta (Duffield, 2001; Goodhand \& Sedra, 2013).

A despeito do processo de securitização desses estados, vale ressaltar que ele antecede os atentados de 11/9, mas é após essa data que ele ganha força e se explicita discursivamente.

O estudo de caso desenvolvido nos aponta empiricamente, tanto pela análise dos discursos como a observação da prática e de suas consequências, como de fato o norte se torna objeto referente predominante. Anteriormente, era evidente a presença da segurança humana, que embora fosse segurança do estado sob disfarce do indivíduo como objeto referente, nos discursos tanto do complexo da governança global como de governantes.

Porém, o nexo entre segurança e desenvolvimento já molda políticas com relação ao subdesenvolvimento desde a década de 1990 
The reproblematisation of security in terms of underdevelopment becoming dangerous has added urgency and justification to development's new radical agenda of social transformation. A new security framework has emerged in which stability is now regarded as unfeasible without development, while development is non-sustainable without stability (Duffield, 2001, p. 259).

A tecnologia de segurança utilizada, portanto, em tais processos transformativos, é o desenvolvimento. O desenvolvimento e sua implementação se traduzem em um conjunto de tecnologias e instituições.

Para além de ser uma tecnologia de segurança, devemos acrescentar que tal denominação perpetua diferenças e marginalizações. Em primeiro lugar, porque define a existência de um modelo ideal que deve ser seguido, que se coloca como superior a outros. Em segundo lugar, porque cria uma divisão cujas raízes se encontram no racismo. Conforme explica Duffield (2007, p. 217):

In presenting development as a technology of security, development and underdevelopment are distinguished biopolitically, that is, as connected but separate assemblages of institutions, techniques and interventions by which life is supported and distinguished internationally. In this respect biopolitcs is not a single strategization of power in the sense of a globalizing or universal disposition for acting on and promoting life at the level of world population. Reflecting its organic ties with racism, development embodies the biopolitical division and separation of the human species into developed and underdeveloped species-life.

Assim, tal discurso que cria tais diferenças cria legitimidade para que a ação possa ocorrer, gera aceitação política de suas respectivas populações pois transmite a crença de que se estaria levando bem-estar, segurança e uma vida melhor aos indivíduos receptores.

Há também uma retomada explícita da preocupação intrínseca ao liberalismo com relação à segurança, e a função do estado como quem salvaguarda a liberdade de seus indivíduos. A segurança e a liberdade, dessa maneira, seriam indissociáveis. A exportação do modelo da paz liberal vem carregada de um liberalismo calcado no controle e no poder. Ou seja, a paz liberal pode ser vista como biopolítica.

O que nos vale, e que o estudo empírico nos ilustrou, principalmente através da observação de que o indivíduo afegão foi marginalizado, é como, de fato, a dualidade segurança e desenvolvimento refletem técnicas de poder liberais; são colocadas em prática para penetrar a vida humana e controla-la em seu dia-a- 
dia, e não para levar liberdade e bem-estar. Uma das descobertas, no entanto, é que nem mesmo o discurso americano ou britânico se preocuparam em abordar o indivíduo afegão. O subdesenvolvimento sim foi transmitido como ameaça e como instável, mas esses problemas deveriam ser sanados, em última instância, apenas para a segurança americana e britânica.

A relação entre o Norte e o Sul, o Ocidente e os países que recebem as missões e operações de paz é aqui representada pela OTAN, Estados Unidos e Reino Unido versus o Afeganistão. Ou seja, a segurança é a tecnologia que imporá a ordem e moldará uma sociedade que é instável e apresenta uma ameaça constante. E, como vimos na parte teórica e conceitual do presente trabalho, para além da liberdade de seus indivíduos, é a segurança que é o valor central ao liberalismo.

Por fim, acerca de concepções de segurança e quais as mudanças que o 11/9 provocou, enquanto a década de 1990 se via em meio a uma mudança crescente de objeto referente em direção ao indivíduo, os atentados trouxeram um retrocesso nesse quesito. Assim, houve impacto sobre o uso da segurança humana como tecnologia de governança, conforme aponta Duffield (2007, p. 126). Houve uma retomada do objeto referente como sendo o estado e sua segurança nacional. Houve, por exemplo, a criação do Homeland Security Department nos Estados Unidos, o que atesta tal afirmação. Além disso, os discursos britânicos e americanos atestaram também, por exemplo, que estariam no Afeganistão pela segurança nacional de cada um. Ou seja, é um retorno a uma concepção de segurança que não engloba o indivíduo ou outros elementos como objetos referentes.

Há um retorno a uma agenda restrita cujo único objeto referente que pauta ações práticas é o próprio estado. Ou seja, observa-se que os dois objetos sempre coexistem, porém, dependendo do contexto político, um pode prevalecer sobre o outro.

A estabilidade, sobretudo do sistema, do norte em relação ao sul, é que está em jogo. É necessário conter as instabilidades, e isso é feito através do peacebuilding e da paz liberal. Mais do que isso, é preciso conter também o terrorismo, mas através do controle intenso das fronteiras nacionais. Embora o terrorismo seja uma ameaça não-estatal, é através da segurança interna e contenção de instabilidades que o terrorismo será terminado: "Securing freedom 
necessitates stopping the spread of terrorista networks through closing home bases, preventing new sanctuaries from forming and stemming the proliferation of weapons, funds and recruits (Duffield, 2007, p. 126)". Portanto, para prover segurança no âmbito nacional, é necessário voltar atenção a espaços tidos como vulneráveis, instáveis, ou falidos. A paz liberal se consolida, desse modo, como um processo colonizador, que leva controle e tecnologia de segurança e de poder de modo imposto para assegurar determinados interesses do ocidente.

Assim, há um paradoxo em relação a ética liberal em sua transmissão através da paz liberal. Duffield (2007, p. 129) argumenta que, invoca-se os valores da liberdade e dos direitos ao mesmo tempo em que se reconhece que, para garantir determinado fim, é necessário o uso do despotismo. Por fim, aqui observamos o uso liberal da exceção, em que, em nome da segurança, qualquer ato pode ser colocado em prática, até mesmo subordinar direitos humanos, conforme os acontecimentos após os atentados nos confirmaram. É, como Jabri (2006) também nos demonstrou, como a securitização pode levar também a guerra, demonstração máxima do uso da exceção.

\section{3}

\section{As Relações entre Liberalismo e a Paz Liberal}

Embora uma das principais descobertas da pesquisa tenha sido a respeito do desvio quanto a aderência a ética liberal enquanto por sua implementação através da paz liberal no período referido, essa dissertação se baseia também na literatura crítica disponível sobre essa ideologia, tida como um projeto hegemônico, exclusivo, e radical.

Uma das primeiras questões a ser levada em consideração diz respeito a relação entre bem-estar e economia formal. Conforme demonstramos ilustrativamente através da questão das drogas no Afeganistão, do ponto de vista geral, as shadow economies em meio a esse contexto de relações entre norte e sul globais atestam que a presença de tais economias na maioria dos países do sul comprova que o modelo exportado pelo norte não obtém sucesso nesse quesito. Tanto Pugh (2005) quanto Duffield (2001) nos apontam para essa direção, e os dados empíricos a respeito do Afeganistão e sua produção de ópio a partir do 
início da missão de peacebuilding coordenada pela OTAN nos ilustram que os argumentos de ambos os autores é verídico.

Em primeiro lugar, Pugh (2005) defende em sua obra que economias de sombra representam uma busca por um bem-estar, que para ele, não deveria ser associado a aumento no poder de consumo, tal como ocorre, na prática, através da exportação do modelo liberal. Além disso, tal modelo acarreta também em um processo de marginalização de qualquer alternativa de possibilidade local para o bem-estar, bem como para a paz, e, por conta disso, acabam recorrendo a economias de sobra. No entanto, esse tipo de economia não é reconhecido pelos atores responsáveis pela implementação da paz liberal, que as subjugam e as mantêm ilegítimas e informais. Isso implica também que a modificação de sistemas econômicos locais por agentes externos pode ocasionar em consequências inesperadas. Os discursos colocam o capitalismo e o liberalismo como as únicas opções que podem trazer a paz.

Além disso, as economias de sombra são também um modo pelo qual os locais procuram para se inserir em um sistema altamente excludente. O projeto da paz liberal, além disso, se responsabiliza por determinar e construir o que é uma atividade de risco ou o que é uma economia informal (Duffield, 2001).

O modo de inserção através das economias de sombra é, além de ser uma busca pelo bem-estar, uma busca por vantagem tanto política quanto econômica, principalmente sob o contexto de um conflito. Tais economias se constituem através de sistemas alternativos, tanto de poder, quanto de lucro, que se estendem através de redes amplas, que penetram na legalidade. Elas também adquirem força e legitimidade na medida em que passam a oferecer proteção a quem passa a fazer parte do complexo.

Não é apenas pela falta de prover bem-estar que o liberalismo tal como transmitido pela paz liberal se diz inconsistente com as suas tradições.

As operações no Afeganistão e no Iraque, por exemplo, foram essencialmente militares, de modo que os objetivos iniciais eram limitados a guerra ao terror. No entanto, por falta de estratégias de saída consistentes, as operações se expandiram e outras estratégias passaram a ser utilizadas para conter a proliferação de outras ameaças terroristas. Assim, as duas operações se mostraram oportunidades retóricas para os Estados Unidos, que enxergou no peacebuilding um modo para se atingir o objetivo final, e, para Bush, um modo 
para conquistar a reeleição, conforme colocado por Goodhand e Sedra (2013). Mais uma vez, foram medidas tomadas em nome da segurança, e não em nome de valores liberais, em primeiro lugar.

Os dois autores acrescentam também que a paz liberal pós 11/9 se baseia em uma noção contratualista em que o estado proverá a segurança e os serviços públicos. Richmond (2011) também enxerga a paz liberal como um contrato, e ressalta que se assimila com um contrato comercial, em que o norte, ou os Estados Unidos e a OTAN, se posicionam como gerentes. E, obter aceitação de tal contrato pelo sul se mostra atrativo para o norte, que, na função de gerente, consegue exercer a governamentalidade para controle total de tais espaços instáveis (Richmond, 2011). Assim, o estado criado pela paz liberal, é um grande paradoxo, como apontam Rubin (2007), Goodhand e Sedra (2013) e Richmond (2011). Primeiro, pois sua formação é imposta e não corresponde aos processos pelos quais os estados europeus passaram. Em segundo lugar,

(...) a form of 'liberal state' has emerged which is fortified, militarised, spends most of its revenue on security, provides massive public sector employment to avoid humanitarian emergency, and is underpinned by quickly rotated international personnel (often US military or advisors) (Richmond, 2011, p. 2).

Mais uma vez, observamos a centralidade da segurança em face dos indivíduos na paz liberal no período estudado. Richmond (2011, p.5) também atenta para outra observação feita com base no estudo de caso. Há foco no mercado vis-a-vis a ética liberal que se foca no indivíduo. A paz liberal sendo veiculada corresponde a valores ligados ao estado como instituição e ao mercado. Assim, existem outras prioridades na década de 2000 que se sobrepõe a preocupação com o indivíduo, a saber: a segurança e o terrorismo.

Ainda a despeito do indivíduo local, observamos que, dentro do discurso da paz liberal, ele é construído como exótico. É construído também como algo que precisa de ajuda, que não atingirá o progresso sem apoio e sem a consagração do modelo liberal.

Portanto, Richmond (2011) concorda, que, além de incorporar as necessidades locais ao projeto em si, ele tampouco é consistente com a ética liberal tradicional.

Grand institutional solutions to local conflicts fail to address the dynamics of the local, or the problems of such institutional designs (which are probably no more 
sophisticated than the operatives who control them and implement their mechanistic approaches, and certainly are not able to comprehend the local, the diverse or the different). These represent metanarratives of governance, not peace or peacebuilding. Moreover, they are not even wholly consistent with political liberalism except in its most conservative forms (Richmond, 2011, p. 65).

Em resumo, concluímos como a paz liberal, sobretudo no que se diz respeito a década de 2000, não aderiu a ética liberal cujo cerne é a importância do indivíduo. Observamos, também, que enquanto o discurso da década de 1990, sob influência da segurança humana, colocava o indivíduo como objeto referente, os atentados de 11/9 acarretaram em um retorno a uma concepção de segurança tradicional em que o estado volta a ser o objeto referente, em que a segurança nacional se torna prioridade e medidas que ultrapassem as leis são permitidas em nome da proteção desse espaço. Por outro lado, uma desconstrução do liberalismo também nos revela que a segurança é de fato uma prioridade, que a exceção existe precisamente para esse fim, e que é o estado, em última instância, o responsável por garantir a segurança, que, por sua vez, garantirá a liberdade do indivíduo. Assim, a centralidade do indivíduo é questionável se observamos sob o prisma da segurança. A ascensão de um objeto em face de outro nos aponta para uma existência de uma concorrência entre os dois objetos. São discursos que entram em embates, e um sai vitorioso, enquanto o outro não. Porém, seguem coexistindo, e tais embates correspondem a diferentes momentos históricos, diferentes contextos, agendas políticas sobretudo se forem hegemônicas. Há que se destacar também que, no caso do Afeganistão, embora a segurança ocidental tenha se sobressaído, não houve negação total da parte social e humanitária nas operações. Ela não foi inexistente, e o componente humanitário ainda faz parte do escopo de tais operações.

\section{4}

\section{Conclusões Sintéticas}

Para compreender as motivações reais - ou, em outros termos, objetos referentes - que pautam as operações de peacebuilding, vários elementos tiveram de ser observados ao longo desse trabalho.

Em primeiro lugar, jogamos luz sobre o liberalismo como ideologia e tradição filosófica, que coloca o indivíduo em primeiro lugar, mas, quando observamos de perto a paz liberal, isso não se mostra tão verdadeiro. De fato há 
uma dualidade de objetos referentes por trás desse projeto, mas um se sobrepõe ao outro. A segurança nacional dos mandantes acaba se sobrepondo ao bem-estar dos indivíduos receptores, embora alguns discursos (nem todos), cheguem a incluí-los.

Observamos também que isso corresponde a determinadas mudanças sobretudo em relação aos atentados de 11 de setembro de 2001. Determinadas ações, anteriormente, de fato foram enviadas com fins humanitários. Deve ser ressaltado, inclusive, que o componente humanitário em tais operações jamais é abandonado por completo. Mas, o que houve no Iraque, e, principalmente, no Afeganistão, foi sobretudo para atender os interesses dos Estados Unidos e de seus aliados, que colocam suas respectivas seguranças nacionais em primeiro lugar.

Ao desconstruir o discurso liberal propriamente dito, vemos, que, de fato, segurança é um dos, se não for, o valor central. Liberdade está vinculada a noção de segurança: os indivíduos, para serem livres, só o são se tiverem segurança. O estado é responsável por essa troca. Fornece segurança para que exerçam liberdade.

Assim, quanto as principais descobertas dessa pesquisa, em primeiro lugar, vemos que há uma clara distância entre discurso e prática, em especial no que tange a objetos de referência.

Enquanto determinados discursos delimitam, por exemplo, dois objetos, a população afegã, e a segurança nacional americana ou britânica, os respectivos atos em solo afegão apontam para apenas a segurança nacional como objeto referente de fato - conforme os dados a respeito das drogas nos levantam, e a continuidade da violência no Afeganistão devido ao movimento insurgente do Talibã.

Outra descoberta, a despeito da trajetória da construção do estado afegão, notamos uma clara tendência por parte das tentativas de se impor um estado, em marginalizar o indivíduo desde então. Nunca houve tentativa de desenvolvimento interno, embora existisse coleta de impostos, e uma grande dependência de recursos externos.

Embora isso não havia sido previsto na pesquisa, de início, o que podemos concluir é que a OTAN e os Estados Unidos acabaram por dar continuidade a essa marginalização a população afegã, que se cristaliza no ápice da produção do ópio, e, agora, com a retirada das tropas, o futuro pode parecer incerto, por um lado. 
Mas por outro, sabemos que a história do Afeganistão continuará seguindo uma mesma trajetória infeliz aos seus habitantes.

Por fim, a despeito do objeto de estudo central dessa dissertação, o caso no Afeganistão nos comprovou a sobreposição de objetos referentes na paz liberal após o 9/11. Ou seja, os estados mandantes, representados pela OTAN, indicaram claramente tanto no discurso quanto no campo que a missão de peacebuilding empreendida no Afeganistão foi em nome de suas seguranças nacionais. E, ainda, tais missões se traduzem em uma continuação do nexo entre segurança e desenvolvimento, em que há um processo de securitização do sul, no caso, do Afeganistão, que, nos discursos foi representado como uma ameaça constante, e que para estabilizá-lo, e trazer segurança para o norte, seria necessário levar desenvolvimento. Assim, a paz liberal se comprova como um projeto radical, que marginaliza os locais, implementa as forças um modelo liberal não tão preocupado com o indivíduo receptor e sua liberdade, mas sim em inseri-lo em uma política de governamentalidade, de controle do dia-a-dia em nome da segurança, que se disfarça de liberdade em meio ao discurso liberal. 


\section{Referências Bibliográficas}

ABRAHAM, I; VAN SCHENDEL, W. Illicit Flows and Criminal Things. Bloomington: Indiana University Press, 2005

ACHARYA, A. Human Security. In: BAYLIS, J.; SMITH, S.; OWENS, P. The Globalization of World Politics. Oxford: Oxford University Press, 2011. Cap. 29, p. 478.

ACHIM, W. Ending Wars, Consolidating Peace: Economic Perspectives. 1. ed. [S.1.]: Routledge, 2010. Cap. 2, p. 258.

BALDWIN, D. The Concept of Security. Review of International Studies, Vol. 23, pp. 5-26, 1997

BARAKAT, S.; DELY, S.; ZYCK, S. A. 'A tradition of forgetting': stabilisation and humanitarian action in historical perspective. Overseas Development Institute, 2010. 1-23.

BELlamy, A. \& WILliamS, P. Understanding Peacekeeping. Cambridge: Polity Press, 2011

BENTHAM, J. An Introduction to the Principles of Moral and Legislation, $1823 . \quad$ Disponível em: <http://www.earlymoderntexts.com/pdfs/bentham1780.pdf>

BOOTH, K. Critical Securty Studies and World Politics. Boulder: Lynne Rienner Publishers, 2005

BUENO DE MESQUITA, B. An Institutional Explanation of the Democratic Peace. American Political Science Review. Vol. 93, N. 4, 1999. 
BURKE, Jason. Al Qaeda. Rio de Janeiro: Jorge Zahar, 2007

On the road to Kandahar. Londres: Penguin, 2007

BUSH, G. W. A Nation Challenged. 8 de out. 2001 Disponível em: $<$ http://www.nytimes.com/2001/10/08/us/a-nation-challenged-bush-s-remarks-onus-military-strikes-in-afghanistan.html >

BUZAN, B.; HANSEN, L. A Evolução dos Estudos de Segurança Internacional. São Paulo: Editora UNESP, 2012

BUZAN, B.; WAEVER, O.; WILDE, J. Security: A new framework for analysis. Colorado: Lynne Rienner Publishers, 1998.

BUZAN, B. People, States and Fear. Brighton: Wheatsheaf Books, 1983

COLLINSON, S.; MUGGAH, R.; SAMIR, E. States of fragility: stabilisation and its implication for humanitarian practice. Humanitarian Policy Group Working Paper. Londres, Reino Unido, p. 24. 2010.

CAMPBELL, S; CHANDLER, D; SABARATNAM, M. A Liberal Peace? Nova Iorque: Zed Books, 2011

CARMENT, D; PREST, S; SAMY, Y. Security, Development and the Fragile State. Nova Iorque: Routledge, 2011

CHANDLER, D. From Kosovo to Kabul. Ann Arbor: Pluto Press, 2002

Security-development nexus and the rise of 'anti-foreign policy'. Journal of International Relations and Development. Volume 10, N. 4, 2007

CHETAIL, V. Post-Conflict Peacebuilding: A Lexicon. Oxford: OUP, 2009

COCKAYNE, James; PFISTER, Daniel. Peace operations and Organised Crime. International Peace Institute (IPI), Geneva Papers, nº2, 2008.

COLLINSON, S.; MUGGAH, R.; SAMIR, E. States of fragility: stabilisation and its implication for humanitarian practice. Humanitarian Policy Group Working Paper. Londres, Reino Unido, p. 24. 2010.

CONSELHO de Segurança das Nações Unidas. Bonn Agreement. 5. Dez.2001. Disponível em: < http://www.un.org/News/dh/latest/afghan/afghan-agree.htm> 
DEPARTAMENTO de Estado dos Estados Unidos da América. International Narcotics Control Strategy Report - Vol. 1 - Drug and Chemical Control. Washington, 2011.

DOTY, R. Foreign Policy as Social Construction: A Post-Positivist Analysis of US Counterinsurgency Policy in the Philippines. International Studies Quarterly, Vol. 37, 1993.

DOYle, M. Liberalism and World Politics, The American Political Science Review, Vol. 80, No. 4, pp. 1151-1169, 1986

Liberal Peace: Selected Essays. New York: Routledge, 2012

DOYle, M. \& SAMBANIS, N. Making War \& Building Peace. New Jersey: Princeton University Press, 2006

DUFFIELD, M. Development, Security and Unending War. Cambridge: Polity Press, 2007

Global Governance and the New Wars. Londres e Nova Iorque: Zed Books, 2001

The Liberal Way of Development and the DevelopmentSecurity Impasse: Exploring the Global Life-Chance Divide. Security Dialogue. Vol. 41, No. 1, 2010

ESCRITÓRIO das Nações Unidas Sobre Drogas e Crimes. Addiction, crime and insurgency: the transnational threat of Afghan opium. Viena: UNODC, 2009a.

$2012 b$

Drug Use in Afghanistan: 2009 Survey. Viena: UNODC,

Opium Survey 2012. Viena: UNODC, 2012

. Opium Survey 2013. Viena: UNODC, 2013

Opium Survey 2014. Viena: UNODC, 2014a

World Drug Report 2014. Viena: UNODC, 2014b

EWANS, M. Conflict in Afghanistan: Studies in Asymetric Warfare. Nova Iorque e Londres: Routledge, 2005

EXÉRCITO Britânico. Reconstruction and Development. [S.D, s.n]. Disponível em:〈http://www.army.mod.uk/operations-deployments/22802.aspx> 
FELBAB BROWN, V. Peacekeepers Among Poppies. International Peacekeeping, 16:1, pp. 100-114, 2009

Counterinsurgency, Counternarcotics, and Illicit Economies in Afghanistan: Lessons for State-Building. In: BREWER, J.; MIKLAUCIC, M. Convergence: Illicit Networks and National Security in the Age of Globalization. Washington: National Defense University Press, 2013

FINNEMORE, M. Paradoxes in humanitarian intervention. Em Richard M. Price, org., Moral Limit and Possibility in World Politics. Cambridge: Cambridge University Press, 2008

FISHSTEIN, P; WILDER, A. Winning Hearts and Minds? Examining the relationship between aid and security in Afghanistan. Medford: Tufts University, 2011

GOODHAND, J, SEDRA, M. 'Rethinking Liberal Peacebuilding, Statebuilding and Transition in Afghanistan: An Introduction.' Central Asian Survey, 32 (3). pp. 239-254, 2013

GOODHAND, J. Corrupting or Consolidating the Peace? The Drugs Economy and Post Conflict Peacebuilding in Afghanistan.' International Peacekeeping, 15 (3). pp. 405-423, 2008

. Frontiers \& Wars: The Opium Economy in Afghanistan. Journal of Agrarian Change, 5:2. 191 - 216, 2005

. From war economy to peace economy? Reconstruction and statebuilding in Afghanistan. Journal of International Affairs, Special Edition on International Institutions and Justice, 58 (1). pp. 155-174, 2004

GOODSON, L. The Fragmentation of Culture in Afghanistan. Alif: Journal of Comparative Poetics, Cairo. No. 18, pp. 269-289, 1998

GORDON, S. The United Kingdom's stabilisation model and Afghanistan: the impact on humanitarian actors. Disasters, Oxford, v. 34, n. S3, 2010.

GOVERNO Britânico. Ministry of Defence Top Level Messages. Outubro, $2014 . \quad$ Disponível em: $<$ https://www.gov.uk/government/uploads/system/uploads/attachment_data/file/3 63081/tlm_October2014.pdf>

HALliDAY, F. The Middle East in International Relations. Cambridge: Cambridge University Press, 2005 
HAMMOND, T. Bandeira Vermelha no Afeganistão. Rio de Janeiro: Biblioteca do Exército, 1987

HARPVIKEN, K. Transcending Traditionalism: The Emergence of Non-State Military Formations in Afghanistan. Journal of Peace Research, Oslo, Vol. 34, No. 3, pp. 271-287, 1997

HARTMAN, A. 'The Red Template': US Policy in Soviet-Occupied Afghanistan. Third World Quarterly, Vol. 23, No. 3, pp. 467-489, 2002

HEHIR, A. The Responsibility to Protect: Rhetoric, Reality and the Future of Humanitarian Intervention. Nova Iorque: Palgrave MacMillan, 2012

HOPPER, P. Understanding Development: Issues and Debates. New York: Polity, 2012; pp. 116-138.

HYMAN, A. Nationalism in Afghanistan. International Journal of Middle East Studies, Cambridge, Vol. 34. No.2.pp. 299-315, 2002

JABRI, V. War, Security and the Liberal State. Security Dialogue, Vol. 37, n. 1, 2006

KALDOR, M. New and Old Wars: Organized Violence in a Global Era. Palo Alto, CA: Stanford University Press, 1999.

KALDOR, M. New \& Old Wars. Stanford: Polity Press, 2001

. Human Security: Reflections on Globalization and Intervention. Cambridge: Polity Press, 2007

KANT, I. A Paz Perpétua. São Paulo: Perspectiva, 2004

KENKEL, K. M. Five Generations of Peace Operations: From the "Thin Blue Line" to "Painting a Country Blue". Revista Brasileira de Política Internacional, 56, 1, 122-143, 2013.

KRAUSE, K; WILlIAMS, M. Critical Security Studies. Londres: UCL Press, 1997

LOCKE, J. Second Treatise of Government, [S.I.; s.n], 1689. Disponível em: <http://www.earlymoderntexts.com/pdfs/locke1689a_1.pdf>

MACFARLANE, S.; KHONG, Y. Human Security and the UN. Bloomington: Indiana University Press, 2006

MERCILLE, J. Grading drug war in Afghanistan a decade after. Open Democracy, set 2013. Disponível em: <http://www.opendemocracy.net/julienmercille/grading-drug-war-in-afghanistan-decade-after-f $>$ Acesso em: 10 de junho de 2014 
MILL, J. Utilitarianism. [S.I; s.n], 1863. Disponível em: < http://www.earlymoderntexts.com/pdfs/mill1863.pdf>

MILLIKEN, J. The Study of Discourse in International Relations: A Critique of Research and Methods. European Journal of International Relations, Vol 5, No. 2, 1999

MUGGAH, R. Stabilising Fragile States and the Humanitarian Space. In: BERDAL, M.; ACHIM, W. Ending Wars, Consolidating Peace: Economic Perspectives. 1. ed. [S.1.]: Routledge, 2010. Cap. 2, p. 258.

NAÇÕES Unidas. Secretary-General. An Agenda for Peace: preventive diplomacy, peacekeeping and peace-making, 1992. A/47/277 - S/24111. Disponível em: <http://www.un.org/Docs/SG/agpeace.html>. Acesso em 4 de agosto de 2014.

Report of the Panel on United Nations Peace Operations. A/55/305

- S/2000/809. Agosto de 2000 Disponível em:
<http://www.un.org/peace/reports/peace_operations/>. Acesso em 4 de agosto de 2014.

NEOCLEOUS, M. Critique of Security. Edimburgo: Edinburgh University Press, 2008

NEWMAN, E.; PARIS, R.; RICHMOND, O. New Perspectives on Liberal Peacebuilding. Tóquio: United Nations University Press, 2009.

NORDSTROM, C. Shadows of Wars. Berkeley e Los Angeles: UCP, 2004

OBAMA, B. Remarks at the State Department. 22 jan. 2009a. Disponível em: $<$ http://www.presidency.ucsb.edu/ws/index.php?pid=85694\&st=afghanistan\&st $1=$ opium>

. Statement of Administration Policy. 25 set. 2009b. Disponível em: $<$ http://www.presidency.ucsb.edu/ws/index.php?pid=86689\&st=afghanistan + $\underline{\text { national }+ \text { security } \& \text { st } 1=\% 3 \mathrm{E}>}$

Letter to Congressional Leaders on the Global Deployments of United States Combat-Equipped Armed Force. 12 jun. 2014a. Disponível em: $<$

http://www.presidency.ucsb.edu/ws/index.php?pid=105266\&st=afghanistan+natio nal+security\&st $1=\% 3 \mathrm{E}>$

President's Weekly Address. 13 dez. 2014b. Disponível em: < http://www.presidency.ucsb.edu/ws/index.php?pid=108024\&st=afghanistan\&st1= afghans $>$

OREN, I. The Subjectivity of the "Democratic" Peace: Changing U.S. Perceptions of Imperial Germany,International Security, Vol. 20, No. 2, 1995 
ORGANIZAÇÃO DO TRATADO ATLÂNTICO NORTE. ISAF'S Mission in Afghanistan. $\quad[$ S.D; $\quad$ s.n] Disponível em: <http://www.nato.int/cps/en/natohq/topics_69366.htm>

PARIS, R, GHECIU, A. NATO and the challenge of sustainable peacebuilding. Global Governance, Vol 17, N.1, 2011, p.75

PETERS, G. How Opium Profits the Taliban. Peaceworks, No. 62, 2009

PUGH, M. Military Intervention and Humanitarian Action: Trends and Issues. Disasters 22(4), 1998. 339-351.

Towards Life Welfare. In: NEWMAN, E.; PARIS, R.; RICHMOND, O. New Perspectives on Liberal Peacebuilding. Tóquio: United Nations University Press, 2009. Cap. 4, pp. 78-96.

RAIS, R. Recovering the frontier state. Lanham: Lexington Books, 2008

RASHID, A. Descent into Chaos. Londres: Penguin, 2008

. Taliban: Militant Islam, Oil and Fundamentalism in Central Asia. New Haven: Yale, 2010

. The Taliban: Exporting Extremism. Foreign Affairs, Vol.78, No. 6, pp. 22-35, 1999

RICHMOND, O. A Post-Liberal Peace. New York: Routledge, 2011

2005

The Transformation of Peace. New York: Palgrave Macmillan,

; Human Security and the Liberal Peace: Tensions and Contradictions.2006 EKEM Workshop on International Peacekeeping and Peacemaking: Global and Regional Perspectives

RUBIN, B. Fragmentation of Afghanistan. New Haven e Londres: Yale University Press, 2002

78,2007

. Saving Afghanistan. Foreign Affairs, Vol. 86, No. 1, pp. 57-74, 76-

. Afghanistan and threats to Human Security. Disponível em: < http://essays.ssrc.org/sept11/essays/rubin.htm>. Acesso em: $1^{\circ}$. de julho de 2014.

. Lineages of the State in Afghanistan. Asian Survey, Berkeley, Vol. 28, No. 11, pp. 1188-1209, 1988

RUPERT, J. Afghanistan's Slide Toward Civil War. World Policy Journal, Nova Iorque, Vol. 6, No. 4, pp. 759-785, 1989 
RUSSETT, B. Grasping the Democratic Peace. Princeton: Princeton University Press, 1993

SABARATNAM, M. A Liberal Peace? An Intellectual History of International Conflict Management, 1990-2010. In: CAMPBELL, S.; CHANDLER, D.; SABARATNAM, M;. A Liberal Peace? The Problems and Practices of Peacebuilding. Londres e Nova Iorque: Zed Books, 2011

SAIKAL, A. Afghanistan's Transition: ISAF's stabilisation role? Third World Quarterly, Vol. 27, No. 3, pp 525 - 534, 2006

SCHWELLER, R. Neo-Realisms Status Quo Bias: What Security Dilemma? Security Studies, vol. 5, n. 3, 1996

SHAHRANI, Nazif. War, Factionalism, and the State in Afghanistan. American Anthropologist, Vol. 104, No. 3, pp. 715-722, 2002

SMALL, M; SINGER, J.D. The War Proneness of Democratic Regimes, 18161976. The Jerusalem Journal of International Relations. Vol. 1, No. 4, 1976

STERN, M.; OJENDAL, J. Mapping the Security-Development Nexus. Security Dialogue. Vol. 41, No. 1, 2010

WALT, S. The Renaissance of Security Studies. International Studies Quarterly 35, no. 2, pp. 211-239, 1991.

WALTZ, K. Theory of International Politics. Reading: Addison Wesley, 1979

WEISS, T. Humanitarian Intervention. Cambridge: Polity Press, 2007

WHEELER, N. Saving Strangers: Humanitarian Intervention in International Society. Oxford: Oxford University Press, 2000

WILLIAMS, M. Empire Lite Revisited: NATO, the Comprehensive Approach and State-building in Afghanistan. International Peacekeeping. 18:1, 64-78, 2011.

ZURCHER, C. The Liberal Peace: A Tough Sell? In: CAMPBELL, S.; CHANDLER, D.;

SABARATNAM, M;. A Liberal Peace? The Problems and Practices of Peacebuilding. Londres e Nova Iorque: Zed Books, 2011 